\title{
Modulation of the Oxidative Stress and Lipid Peroxidation by Endocannabinoids and Their Lipid Analogues
}

\author{
Cristina Anna Gallelli ${ }^{1,+} \mathbb{B}^{\mathbb{D}}$, Silvio Calcagnini ${ }^{1,+} \mathbb{( \mathbb { D }}^{\mathbb{C}}$, Adele Romano ${ }^{1}$, \\ Justyna Barbara Koczwara ${ }^{1}$ (D), Marialuisa de Ceglia ${ }^{1}{ }^{(\mathbb{D}}$, Donatella Dante ${ }^{1}$, Rosanna Villani ${ }^{2}$, \\ Anna Maria Giudetti ${ }^{3}$ (D) , Tommaso Cassano ${ }^{4, *(D)}$ and Silvana Gaetani ${ }^{1}$ (D) \\ 1 Department of Physiology and Pharmacology "V. Erspamer", Sapienza University of Rome, \\ Piazzale Aldo Moro 5, 00185 Rome, Italy; cristinaanna.gallelli@uniroma1.it (C.A.G); \\ silvio.calcagnini@uniroma1.it (S.C.); adele.romano@uniroma1.it (A.R.); \\ justynabarbara.koczwara@uniroma1.it (J.B.K); marialuisa.deceglia@uniroma1.it (M.d.C.); \\ donatella.dante@uniroma1.it (D.D.); silvana.gaetani@uniroma1.it (S.G.) \\ 2 C.U.R.E. University Centre for Liver Disease Research and Treatment, Department of Medical and Surgical \\ Sciences, Institute of Internal Medicine, University of Foggia, 71122 Foggia, Italy; rosanna.villani@unifg.it \\ 3 Department of Biological and Environmental Sciences and Technologies, University of Salento, \\ Via Monteroni, 73100 Lecce, Italy; anna.giudetti@unisalento.it \\ 4 Department of Clinical and Experimental Medicine, University of Foggia, Via Luigi Pinto, \\ c/o Ospedali Riuniti, 71122 Foggia, Italy \\ * Correspondence: tommaso.cassano@unifg.it; Tel.: +39-0881-588-029 \\ $\dagger$ These authors contributed equally to this study.
}

Received: 28 June 2018; Accepted: 13 July 2018; Published: 18 July 2018

\begin{abstract}
Growing evidence supports the pivotal role played by oxidative stress in tissue injury development, thus resulting in several pathologies including cardiovascular, renal, neuropsychiatric, and neurodegenerative disorders, all characterized by an altered oxidative status. Reactive oxygen and nitrogen species and lipid peroxidation-derived reactive aldehydes including acrolein, malondialdehyde, and 4-hydroxy-2-nonenal, among others, are the main responsible for cellular and tissue damages occurring in redox-dependent processes. In this scenario, a link between the endocannabinoid system (ECS) and redox homeostasis impairment appears to be crucial. Anandamide and 2-arachidonoylglycerol, the best characterized endocannabinoids, are able to modulate the activity of several antioxidant enzymes through targeting the cannabinoid receptors type 1 and 2 as well as additional receptors such as the transient receptor potential vanilloid 1 , the peroxisome proliferator-activated receptor alpha, and the orphan $\mathrm{G}$ protein-coupled receptors 18 and 55. Moreover, the endocannabinoids lipid analogues $N$-acylethanolamines showed to protect cell damage and death from reactive aldehydes-induced oxidative stress by restoring the intracellular oxidants-antioxidants balance. In this review, we will provide a better understanding of the main mechanisms triggered by the cross-talk between the oxidative stress and the ECS, focusing also on the enzymatic and non-enzymatic antioxidants as scavengers of reactive aldehydes and their toxic bioactive adducts.
\end{abstract}

Keywords: oxidative stress; lipid peroxidation; reactive aldehydes; reactive oxygen and nitrogen species; free radicals; endocannabinoids; cannabinoid receptors; peroxisome proliferator-activated receptors; transient receptor potential vanilloid; G protein-coupled receptors 


\section{Introduction}

Oxidative stress and lipid peroxidation are the consequences of a deregulated redox homeostasis that results in the accumulation of highly reactive molecules and cellular injury, especially in those tissues with a high oxygen consumption, such as heart, kidney, and brain, thus leading to cardiovascular [1,2], renal [3], and neurodegenerative diseases [4-6], just to mention a few. Examples of the possible repercussions of free radical damage are provided in this review with special emphasis on lipid peroxidation-derived reactive aldehydes including acrolein (ACR), malondialdehyde (MDA), and 4-hydroxy-2-nonenal (4-HNE), among others [7].

To get a deeper insight into the cellular pathways that regulate reactive oxygen and nitrogen species (ROS/RNS) as well as reactive aldehydes formation, there is a growing interest in identifying free radical scavenging molecules that can prevent cell death following oxidative stress-induced damage of cellular membranes. In this perspective, over the last few years, the endocannabinoid system (ECS) has attracted significant attention because of the existing cross-talk between endocannabinoids (ECs) as well as their lipid analogues and various redox-dependent processes. Therefore, the pathways by which the ECs and their lipid-related mediators contribute to the modulation of oxidative stress and lipid peroxidation represent a significant research area that will yield novel pharmaceutical strategies for the treatment of diseases characterized by a redox imbalance.

The cannabinoid receptors type 1 (CB1) and 2 (CB2), together with additional ECs receptor targets, take part in the complex ECS and, because of their wide distribution, they may play a role in mediating the antioxidant properties of ECs [8-10]. However, the great diversity of results in this field discloses the requirement of a better understanding on the pathways by which these receptors are involved in regulating oxidative stress and lipid peroxidation processes.

In this review, we will provide an overview of the role of the ECS in pathological conditions related to a redox status imbalance, leading to a better comprehension of the intricate routes that are associated to the antioxidant properties exerted by the ECs, thus enhancing the research in finding a therapeutic benefit for cannabinoid-based drugs in various redox-dependent disorders.

\section{Oxidative Stress and Lipid Peroxidation}

Oxidative stress can be described as an imbalance between the production of oxidant species and the antioxidant defenses, which may affect cellular redox homeostasis leading to molecular alterations and thus resulting in cell and tissue damage [11]. The term "oxidants" is a general term used to identify several groups of reactive molecules among which ROS and RNS are considered the most interesting from a biological point of view. ROS/RNS are natural byproducts of aerobic metabolism and are produced by all living multicellular organisms. ROS include free oxygen radicals and non-radical molecules, such as superoxide anion $\left(\mathrm{O}_{2} \bullet^{-}\right)$, hydroxyl $(\bullet \mathrm{OH})$, peroxyl, alkyl, and alkoxyl radicals, as well as singlet oxygen $\left({ }^{1} \mathrm{O}_{2}\right)$, hydrogen peroxide $\left(\mathrm{H}_{2} \mathrm{O}_{2}\right)$, ozone $\left(\mathrm{O}_{3}\right)$, and hypochlorous acid $(\mathrm{HClO})$, while RNS include nitrogen compounds such as nitric oxide $(\bullet \mathrm{NO})$, nitrogen dioxide $\left(\mathrm{NO}_{2} \bullet\right)$, nitrate $\left(\mathrm{NO}_{3}{ }^{-}\right)$, nitrite $\left(\mathrm{NO}_{2}{ }^{-}\right)$, and peroxynitrite $\left(\mathrm{ONOO}^{-}\right)[12,13]$.

In mammals, the main cellular sources of ROS/RNS are the mitochondrial and microsomal electron transport chains [14], the NADPH oxidase enzymes (NOXs), which consist of seven isoforms with various tissue distributions and mechanisms of activation $[15,16]$, the flavoenzyme endoplasmic reticulum oxireductin 1 [17], nitric oxide synthase (NOS) [18], cytochrome P450 enzymes [19], cyclooxygenases (COXs), lipoxygenases (LOXs) [20], xanthine oxidase [21], diamine oxidase [22], and prostaglandin synthase [23]. In addition to these endogenous sources, the ionizing radiation, ultraviolet rays, pathogens, xenobiotics (e.g., drugs, herbicides, fungicides, trace metals, etc.), and environmental pollutants (e.g., smog, cigarette smoke, smoke from wood combustion, etc.) are identified as exogenous sources of ROS/RNS [24], which may seriously alter the fundamental oxidants-antioxidants balance.

To date, growing evidence confirms that ROS/RNS are produced by healthy cells in a highly regulated fashion in order to maintain the intracellular redox homeostasis. Moreover, ROS/RNS 
regulate several cellular functions ranging from immune defense to gene expression regulation, thus acting as reactive molecules secreted against circulating pathogens [25] or as second messengers of specific signaling pathways [26]. The crucial role played by ROS/RNS in immune defense was demonstrated by the discovery of the chronic granulomatous disorder (CGD), a hereditary disease characterized by NOX type 2 (NOX2)-defective phagocytes [27] which are unable to produce ROS/RNS. This genetic defect leads CGD patients in developing a primary immunodeficiency due to the inability of host innate defense to kill and digest ingested pathogens such as bacterial and fungal cells [28-31]. Moreover, ROS/RNS play also an important role in the cardiovascular system because of their ability to regulate blood pressure. In particular, the endothelial NOX2 isoform regulates the release of $\bullet N O$, the endothelium-derived relaxing factor, which modulates the caliber of blood vessels, through the production of $\mathrm{O}_{2} \bullet^{-}$. In hypertension and other vascular pathologies, NOX2 seems to be up-regulated leading to a reduced $\bullet N O$ bioavailability and to the consequent oxidants-antioxidants imbalance in the endothelium, further worsening the oxidative state [32-34]. Moreover, in vivo studies of single nephron function and in vitro studies performed on perfused juxtaglomerular apparatus preparation demonstrated that also the normal renal functions are modulated by ROS/RNS. In particular, $\mathrm{O}_{2} \bullet^{-}$and $\bullet \mathrm{NO}$, which are generated by NOX type 3 (NOX3) and NOS type 1 (NOS1) enzymes, respectively, modulate afferent arteriolar tone and control $\mathrm{Na}^{+}$reabsorption and renal oxygenation by regulating the tubuloglomerular feedback response [35-37]. Furthermore, in the loop of Henle, ROS/RNS increase the absorption of $\mathrm{NaCl}$ by modulating the activity of the $\mathrm{Na}^{+} / \mathrm{H}^{+}$ exchanger [38,39]. In airway and pulmonary artery smooth muscle cells of the lung, NOX2-generated ROS/RNS act as signaling intermediates, which regulate the proliferation and differentiation by the activation of the nuclear factor- $\mathrm{kB}$ (NF- $\mathrm{kB}$ ) and NOS2, and they further show an important role in $\mathrm{O}_{2}$ sensing [39-41].

Moreover, ROS/RNS formation by mucosal cells of the colon seems to modulate the serotonin production by enterochromaffin cells through a NOXs-dependent system, thus contributing to the regulation of serotonin secretion as well as intestinal motility [42]. ROS/RNS have also a fundamental role in the central nervous system (CNS), in particular in central autonomic neurons. To this regard, ROS/RNS produced by NOX2 in the nucleus of the solitary tract, in the hypothalamic paraventricular nucleus, and in the subfornical organ modulate angiotensin II signaling, thus contributing to the regulation of cardiovascular homeostasis [43,44]. Moreover, in microglia but not in astrocytes, $\mathrm{H}_{2} \mathrm{O}_{2}$ formation by NOX2 enzyme is involved in the regulation of cell proliferation [45].

Beyond the role as signaling molecules, it has been shown that the aberrant ROS/RNS formation is the leading cause of cell and tissue oxidative stress-induced damage. Indeed, it is well known that excessive levels of ROS/RNS may directly damage lipids containing carbon-carbon double bounds such as cholesterol, glycolipids, phospholipids, and polyunsatured fatty acids (PUFAs), which are abundant within cellular membranes. To this regard, free radical-mediated lipid peroxidation of PUFAs is one of the main mechanisms by which ROS/RNS induce the generation of reactive aldehydes [46]. Due to their abundance of reactive hydrogens, PUFAs are more oxidation-prone lipids compared to monounsatured fatty acids. PUFAs include the $\omega-3$ (e.g., linolenic acid, eicosapentaenoic acid and docosahexaenoic acid) and $\omega-6$ (e.g., linoleic acid and arachidonic acids) fatty acids.

Lipid peroxidation is a chain reaction, which, once started, proceeds through three main steps referred to initiation, propagation and termination [47]. Moreover, lipid peroxidation may occur by several mechanisms: (1) free radical-mediated oxidation [47], (2) enzymatic oxidation, and (3) spontaneous oxidation [48]. In this review, we will focus mainly on the free radical-mediated mechanisms that lead to the formation of reactive aldehydes from PUFAs. In particular, the free radical-mediated oxidation of PUFAs occurs through the following reactions: (1) During the initiation phase, ROS/RNS free radicals attack PUFAs ripping off one hydrogen atom, leading to lipid radicals formation. (2) During the propagation phase, lipid radicals react with oxygen molecules, thus producing peroxyl radicals, which, in turn, react with nearby lipids resulting in the formation of 
new lipid radicals and lipid hydroperoxides. Due to their high instability, lipid hydroperoxides are further degraded into reactive secondary products, such as ACR, MDA, 4-HNE and other reactive aldehydes [7]. (3) During the termination phase, peroxyl radicals may react with other radicals thus generating less reactive compounds, which block the propagation phase (Figure 1) [49].
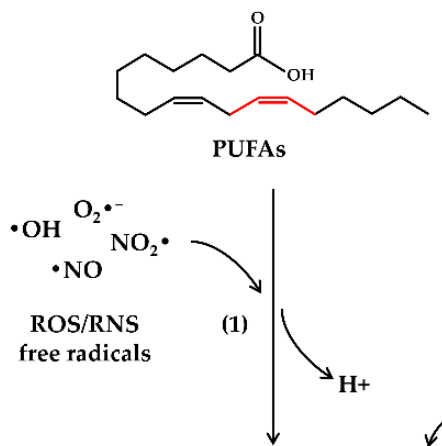

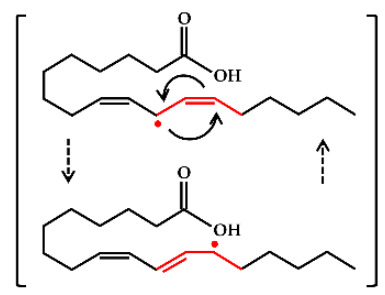

lipid radicals

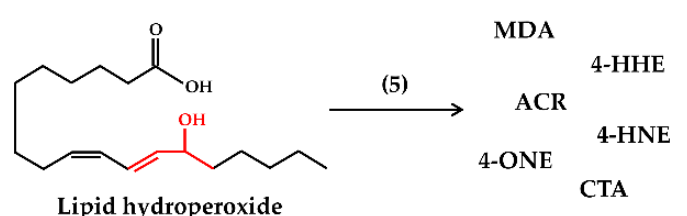

Reactive aldehydes

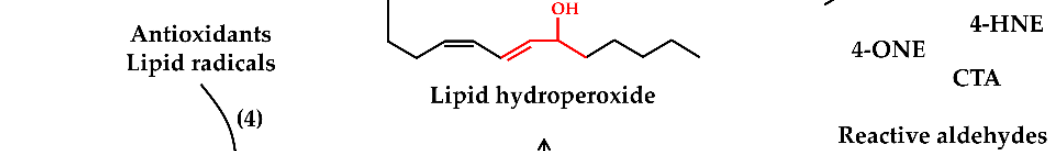

Figure 1. Schematic diagram of the free radicals-mediated peroxidation of polyunsatured fatty acids (PUFAs). ROS/RNS: reactive oxygen and nitrogen species; ACR: acrolein; MDA: malondialdehyde; CTA: crotonaldehyde; 4-HNE: 4-hydroxy-2-nonenal; 4-HHE: 4-hydroxy-hexanal; 4-ONE: 4-oxo-nonenal. During the initiation phase (1), ROS/RNS free radicals react with PUFAs and rip off an allylic hydrogen thus forming lipid radicals. Generally, lipid radicals tend to be stabilized by a molecular rearrangement. (2) In the propagation phase, lipid radicals react with oxygen to form lipid peroxyl radicals, which in turn react with PUFAs or other nearby lipids resulting in the formation of new lipid radicals and lipid hydroperoxides (3). During the termination phase (4), antioxidants or lipid radicals block the propagation phase by donating a hydrogen atom to lipid peroxyl radicals resulting in the formation of non-radical products. Nevertheless, lipid hydroperoxides are highly unstable therefore they are further degraded into reactive secondary products such as ACR, MDA, 4-HNE, and other reactive aldehydes (5).

Today, it is well accepted that oxidative stress and lipid peroxidation are key features in the pathogenesis of several disorders. Indeed, it has been reported that lipid peroxidation products may interfere in vivo with several biological processes, such as substrate-receptor interaction, signal transduction, gene expression, and homeostatic responses to intracellular and environmental stimuli [50-53]. Currently, the main objective of research focused on oxidative stress, lipid peroxidation, and reactive aldehydes is the characterization of the pathogenic mechanisms in several disorders as well as the identification of specific biomarkers for diseases.

Among the reactive aldehydes, the most frequently studied are ACR, MDA, 4-HNE, 4-hydroxyhexanal (4-HHE), 4-oxo-nonenal (4-ONE), and crotonaldehyde (CTA) (Figure 2). 
ACR

MDA<smiles>C=CC=O</smiles>

CTA<smiles>O=CCC=O</smiles><smiles>CCCCCC(O)/C=C/C=O</smiles>

4-HHE<smiles>CCC(O)CCC=O</smiles><smiles>CCCCCC(=O)/C=C/C=O</smiles>

Figure 2. Chemical structures of the main reactive aldehydes produced by lipid peroxidation. ACR: acrolein; MDA: malondialdehyde; CTA: crotonaldehyde; 4-HNE: 4-hydroxy-2-nonenal; 4-HHE: 4-hydroxy-hexanal; 4-ONE: 4-oxo-nonenal.

Some of these compounds are known to contribute to the pathogenesis of several diseases, such as atherosclerosis, rheumatoid arthritis, neuropsychiatric disorders, heart disease, cellular reperfusion injury, cancer, and metabolic disorders such as diabetes and hepatic diseases $[4,5,7,12,54]$. Reactive aldehydes are a group of electrophilic molecules with different features: some of them are very unstable, characterized by a short half-life, while others are long-lived and highly reactive. In the past years, the endogenous formation of reactive aldehydes has drawn great interest. The ability of aldehydes to easily diffuse across biological membranes [55], and to form adducts with macromolecules such as phospholipids, nucleic acids and proteins $[7,46,56-58]$, is of particular concern. Adducts consist of covalent modifications, which involve the formation of Schiff bases or Michael addition reactions. To this regard, the reactive aldehydes toxicity against peptides and proteins is due to their ability to alter their structure and/or function through the formation of cross-links between different amino acid chains, thus potentially leading to the production of aberrant protein aggregates (Figure 3) [59]. Concerning the toxicity of reactive aldehydes against DNA, it has been shown that these compounds may react against nucleobases, among which the most affected is guanine, due to its chemical structure prone to oxidative modifications. The most studied DNA modifications caused by reactive aldehydes are the exocyclic adducts (Figure 4) [57,58,60]. 


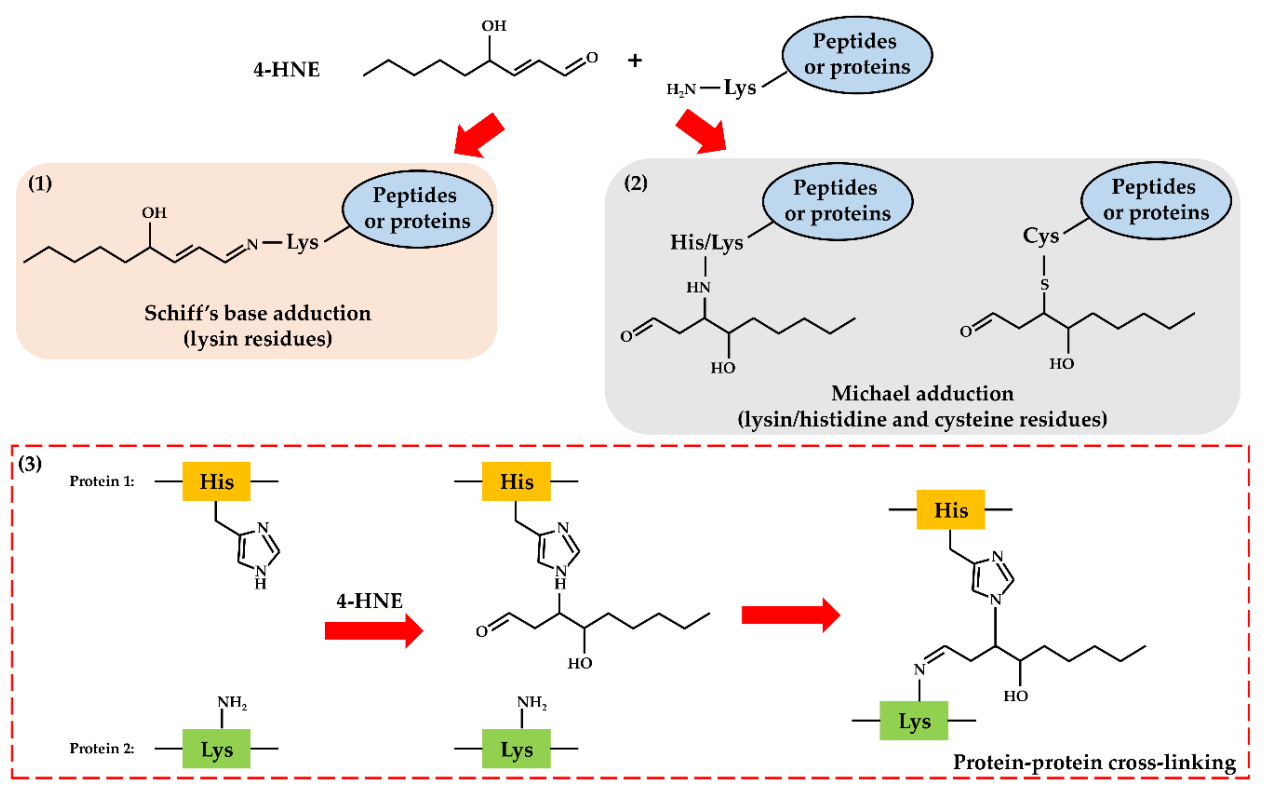

Figure 3. Schematic representation of protein adducts formation and protein-protein cross-linking by 4-HNE. Reactive aldehydes are able to modify peptides/proteins by the formation of toxic adducts which may alter the structure and/or the function of targeted peptides/proteins. These adducts consist of covalent modifications which occur through the formation of Schiff bases or through Michael addition reactions: (1) Schiff base formation on primary amine (lysine residue) through the reaction between peptides/proteins and 4-HNE, (2) Michael addition of 4-HNE on amino groups (lysine/histidine residues) or thiols (cysteine residue) through the reaction between peptides/proteins and 4-HNE, and (3) Protein-protein cross-linking through the reaction between 4-HNE with histidine and lysine residues from different peptides/proteins.

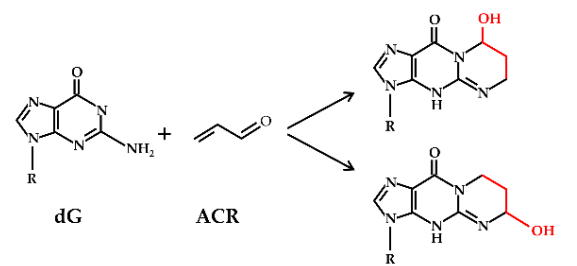

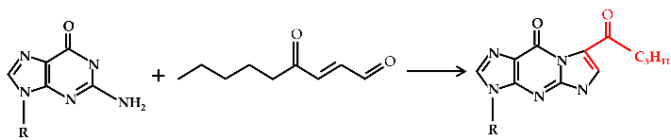

dG 4-ONE

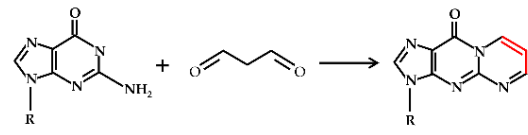

dG MDA<smiles>C/C=C/C=C/C=C/C</smiles>

dG

CTA

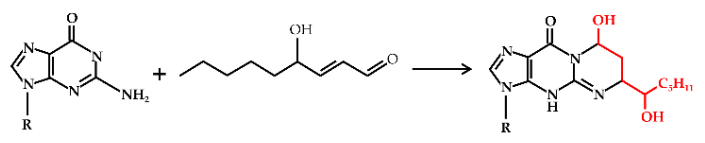

dG

4-HNE

Figure 4. Hypothetical DNA adducts produced by reactive aldehydes.By reacting with DNA, in particular with the deoxyguanosine nucleobases, several reactive aldehydes such as ACR, MDA, 4-HNE, 4-ONE and CTA produce DNA modifications named exocyclic adducts that alter the DNA structure and, if not correctly repaired, may produce carcinogenic effects.

4-HNE and 4-ONE are generated from lipid peroxidation of $\omega-6$ PUFAs (e.g., arachidonic acid and linoleic acid) [61]. Among reactive aldehydes, 4-HNE is the most studied, and its toxic effects 
can be explained by its ability to form protein adducts by reacting with thiols and amino groups of cysteine, histidine, and lysine amino acid residues [62]. For a detailed explanation of the main 4-HNE-modified proteins, see the following publication [63]. 4-ONE is an electrophilic compound that reacts both in vitro and in vivo with nucleobases, in particular with $2^{\prime}$-deoxyadenosine and 2'-deoxycytidine [64-67].

Unlike 4-HNE and 4-ONE, 4-HHE is generated from $\omega$-3 PUFAs (e.g., docoshexaenoic acid, eicosapentaenoic acid and linolenic acid) and, because of its chemical structure, it is considered a soft electrophil with a lower reactivity compared to 4-HNE [7].

MDA, which is widely used as a marker of lipid peroxidation [68], contains at least two unsaturations [7] and is generally produced by PUFAs. Regarding its toxicity, MDA modifies target proteins through the formation of Schiff base complexes, which occur on the amino groups of lysine, histidine, arginine, glutamine, and asparagine amino acid residues as well as on the $N$-terminal of peptide chains [69]. For a detailed explanation of the main MDA-modified proteins, see the following publication [63]. Moreover, in vitro mutagenicity of MDA has been observed by several authors using the Salmonella tiphimurium assay [70-72]. Several studies showed the presence of both MDA and MDA-protein adducts in rheumatoid arthritis patients compared to healthy controls [73-76]. Moreover, high levels of circulating autoantibodies against MDA-modified epitopes have been detected in serum or plasma of patients affected by rheumatoid arthritis [77-79]. CTA or 2-butenal is a carcinogenic aldehyde formed by lipid peroxidation, which is also commonly found in air pollution, in cigarette smoke and in other combustion processes. CTA is able to form adducts with DNA [80-83] and proteins. In accordance with in vitro mutagenesis assay with Salmonella typhimorium, CTA is a mutagenic compound [84] able to induce hepatocellular carcinoma in rats [85]. About protein modifications, CTA reacts preferentially with lysine and histidine amino acid residues, thus forming $\beta$-substituted butanal adducts [86].

ACR or propenal is a metabolite of PUFAs lipid peroxidation, but it is also a ubiquitous environmental pollutant by-product derived by incomplete combustion of organic matter and plastic, cigarette smoke, overheated cooking oils, as well as by anticancer treatment with cyclophosphamide [87,88]. Among reactive aldehydes, ACR is the strongest electrophile, which shows a high reactivity with cysteine, histidine, and lysine amino acid residues. Moreover, ACR forms cyclic adducts with nucleosides in vitro, and is recognized as a potent mutagen [89].

Despite their harmful properties, growing evidence has also demonstrated the hormetic effects of reactive aldehydes [51,63,90-93]. The term "hormesis" refers to a highly conserved and dose-dependent response of biological systems in which low doses of noxious stimuli activate an adaptive response that increases the functionality and/or resistance of the systems to more severe stress. Conversely, high doses of noxious stimuli cause inhibition or detrimental effects [94]. To this regard, low levels of reactive aldehydes may modulate cell signaling, cellular proliferation and many other processes $[7,61,89,95]$. A typical example is represented by 4 -HNE, which may also act as a signaling molecule by modulating the activity of different stress-related transcription factors, such as nuclear factor-erythroid 2-related factor 2 (Nrf2), activating protein-1, NF- $\mathrm{B}$, and peroxisome proliferator-activated receptors (PPARs) [96-100]. Moreover, low levels of 4-HNE may stimulate the activity of protein kinase $\mathrm{C}(\mathrm{PKC})$, may increase cell proliferation, and the expression of cyclooxygenase type 2 (COX-2) and prostaglandin E2 (PGE2) [51].

\section{The Endocannabinoid System: Endocannabinoids, Their Lipid Analogues, and the Receptors}

Over the last years, the ECS has attracted considerable attention as a signaling system because of its emerging regulatory functions in health and disease.

Several components jointly make up the ECS, and they specifically consist of (1) the ECs, endogenous bioactive lipid mediators generated in the brain and in several peripheral tissues; (2) two membrane G-protein-coupled receptors (GPCRs) referred to as CB1 and CB2, and others, 
not yet identified, receptors; and (3) several proteins implicated in the biosynthesis, release, transport, and degradation of these lipid mediators [101].

$\mathrm{N}$-arachidonoyl-ethanolamine or anandamide (AEA) and 2-arachidonoyl-glycerol (2-AG), both derived from the arachidonic acid, are the best characterized members of the main families of ECs ( $N$-acylethanolamines (NAEs) and monoacylglycerols (MAG), respectively) and exert their biological effects by interacting with CB1 and/or CB2 receptors [102]. AEA, an endogenous eicosanoid derivative isolated from pig brain in 1992, was the first EC to be identified [103], and it is well known to modulate several physiological functions being present in the autonomic and in the CNS as well as in the gastrointestinal tract and in the cardiovascular, immune and reproductive systems [104,105].

The second EC ligand to be discovered was 2-AG [106], which has been identified in brain and reproductive tissues in higher concentrations compared to AEA [107-109]. Moreover, 2-AG has also been found in the heart, endothelial cells and circulating cells such as macrophages and platelets [104].

Even though AEA and 2-AG interact with both CB1 and CB2 [110], they show different affinity and efficacy. In particular, depending of on the specific tissue, AEA can be either a partial or a full agonist of CB1, whereas it shows a low overall efficacy for CB2, for which it is a relatively weak ligand [111]. On the contrary, 2-AG appears to be a full agonist of both receptors [112] showing higher CB1 and CB2 efficacy than AEA.

Unlike what has been thought for many years, CB1 expression is not restricted to the brain, where it represents the most abundant of all GPCRs $[113,114]$, but it has been also identified, albeit at much lower concentrations, in various peripheral tissues and cell types including adipose tissue, liver, skeletal muscle, kidney, bone, pancreas, myocardium, human coronary artery endothelial and smooth muscle cells and inflammatory cells (macrophages, lymphocytes) [104,115,116].

In the brain, CB1 is widely present in cerebral cortex, hippocampus, caudate-putamen, substantia nigra pars reticulata, globus pallidus, entopeduncular nucleus, and cerebellum [117]. Interestingly, accumulating evidence supports a new mechanism of action of CB1 signalling in the brain, since it has been found in mitochondria, where it probably modulates neuronal energy homeostasis [118]. On the other hand, the CB2, also known as the "immune cannabinoid receptor", is primarily expressed in immune and hematopoietic cells. However, its presence has also been established at lower, although functionally relevant, levels in the brain, liver, gut, exocrine and endocrine pancreas, reproductive cells, bone, myocardium, human coronary endothelial and smooth muscle cells, and inflammatory cells (e.g., lymphocytes, macrophages, neutrophils) $[104,115,119]$.

CB1 and CB2 are seven-transmembrane-domain proteins both coupled with $G_{\alpha i / o}$ proteins, which inhibit adenylyl cyclase (AC) leading to a reduced protein kinase A (PKA) and PKC activity and to the consequent inhibition of voltage-gated $\mathrm{Ca}^{2+}$ channels and activation of inwardly rectifying $\mathrm{K}^{+}$currents [120]. Furthermore, through a common pathway mediated by $\mathrm{G}_{\alpha o}$ proteins, $\mathrm{CB} 1$ and CB2 are also able to modulate Ras-related protein (Rap) (a member of the Ras small G protein family) and, in particular, it has been postulated that the activation of $G_{\alpha_{0}}$ would release Rap1 guanosine triphosphatase (GTPase) activating protein (Rap1 GAP), which then would be free to inhibit the activity of Rap [121]. Moreover, several observations demonstrated that, depending on the CB1 agonist, this receptor could also interact with $\mathrm{G}_{\alpha \mathrm{s}}$ proteins [122,123].

On the basis of the cell type, the signaling of CB1 and CB2 may also involve $G$ protein independent mechanisms, leading to the activation of mitogen-activated protein kinases (MAPKs) including p38- and p44/42-MAPKs, c-Jun N-terminal kinase (JNK), PKA and PKC, COX-2, and ceramide signaling [124-126].

However, beyond binding the CB1 and CB2 there is increasing pharmacological evidence for additional receptor targets for ECs [127], such as the transient receptor potential vanilloid 1 (TRPV1) [127-129], the PPARs family $[130,131]$ and the orphan G protein-coupled receptors 119 (GPR119), 55 (GPR55) and 18 (GPR18) [132]. TRPV1 is a member of the vanilloid transient receptor potential cation channel subfamily, abundantly expressed in the cardiovascular system, peripheral nervous system, CNS and in epithelial cells of the bladder and the gastrointestinal tract. It is known to 
act by activating PKA and the endothelial nitric oxide synthase (eNOS), thus stimulating the production of $\bullet \mathrm{NO}$ and the release of calcitonin gene-related peptide and substance P $[133,134]$, which, in turn, lead to the altered ion permeability [135].

The finding that some pharmacological actions of AEA can be mediated by the activation of TRPV1 suggests the capability of this endogenous lipid compound to act as an "endovanilloid" [136,137], although AEA induces typical TRPV1-mediated effects with a lower affinity compared to CB1 [127].

PPARs are a family of transcription factors constituted by three different isoforms $(\alpha, \beta / \delta$, and $\gamma)$, widely expressed in tissues with a higher oxidative capacity such as the cardiovascular system and, in particular, cardiomyocytes, endothelial cells, and vascular smooth muscle cells [104], but also in several brain areas and in peripheral tissues such as kidney and liver [138].

After being activated by a ligand, PPARs stimulate gene expression by creating heterodimers with the retinoid $X$ receptor ( $R X R$ ), thereby binding to specific peroxisome proliferator response elements (PPREs) in the promotor region of target genes [139]. They are involved in different biological processes, such as energy homeostasis, lipid and lipoprotein metabolism, cell proliferation and inflammation, blood pressure control and hypertensive-related complications, such as stroke and renal damage $[140,141]$. Furthermore, among the different members of the PPARs family, PPAR- $\alpha$ is recently attracting great attention for its anti-oxidative properties [142].

Moreover, AEA has been shown to exert anti-inflammatory and analgesic actions, and to control feeding behavior by activating the isoform $\alpha$ and $\gamma$ of PPARs receptors $[130,143,144]$. Unlike AEA, 2-AG has no affinity for TRPV1 and is only able to activate PPARs [144,145].

As above mentioned, additional GPCRs were suggested to participate in non-CB1/CB2-mediated actions of ECs including the GPR18, GPR119 and GPR55 [146].

The GPR18, widely expressed in the cardiovascular system, CNS, spleen, and testis, is coupled with $G_{\alpha i / o}$ proteins whose activation results in the $A C$ inhibition and in the modulation of the PI3K/Akt and extracellular signal-related kinases (ERK 1/2) pathways [104]. The $G_{\alpha s}$ coupled-GPR119, primarily expressed in human and rodent pancreas, foetal liver, gastrointestinal tract and in rodent brain, stimulates AC leading to increased intracellular adenosine $3^{\prime}, 5^{\prime}$-cyclic monophosphate (cAMP) levels, thus regulating incretin and insulin hormone secretion [147].

Finally, the GPR55, which is expressed in human brain and liver, but also in rat spleen, vasculature, intestine, foetal tissues, decidua, and placenta, is coupled with $G_{\alpha 12 / 13}$ proteins and increases intracellular $\mathrm{Ca}^{2+}$ via the activation of RhoGTPase nucleotide exchange factors (RhoGEFs) [148].

Different from the classical neurotransmitters, the ECs are not stored in intracellular vesicles but are synthesized "on demand" from membrane phospholipid precursors in response to stimuli that trigger an increase in intracellular $\mathrm{Ca}^{2+}$ levels [131], and then released from postsynaptic neurons to act on presynaptic CB1/CB2 through a retrograde mechanism $[149,150]$. However, recent findings suggested that AEA could be stored inside the cell into adiposomes, which are thought to connect plasma membrane to internal organelles along the metabolic route of this EC [151].

Although 2-AG and AEA are both derived from arachidonic acid, they do not share the same anabolic and catabolic enzymes [126]. Depending on the available precursors and the distinct physiological or pathological conditions [131], AEA can be synthesized by multiple routes. The main pathway for AEA biosynthesis consists of the enzymatic cleavage of the precursor $N$-acyl-phosphatidylethanolamine (NAPE), which is mediated by the NAPE-phospholipase D (NAPE-PLD) [152], whereas the biosynthesis of 2-AG begins with the hydrolysis of 2-arachidonoyl-phosphatidylinositol that occurs through the activity of diacylglycerol lipase (DAGL) and phospholipase $C \beta$ [153].

ECs have a short duration of action, being rapidly metabolized by intracellular enzymes such as fatty acid amide hydrolase (FAAH), the main enzyme responsible for AEA degradation [154-156], and monoacylglycerol lipase (MAGL), which favors 2-AG catabolism [157].

Additional oxidative enzymes, including COX-2, LOXs and cytochrome P450 may also play a role in the metabolism of both AEA and 2-AG by transforming them in bioactive eicosanoids $[158,159]$, which may activate cannabinoid receptor-independent mechanisms [160]. 
Beyond the ECs, several other endogenous mediators have attracted considerable attention, despite some of them showed poor affinity for CB1 and CB2 [126]. Among them, palmitoylethanolamide (PEA), stearoylethanolamide (SEA), and oleoylethanolamide (OEA), belonging to the family of NAEs, are the best characterized. However, other lipid analogues have recently been discovered and include $\mathrm{N}$-arachidonoyldopamine (NADA), Cis-9,10-octadecanoamide (oleamide or ODA), and $\mathrm{N}$-arachidonoylglycine (NAGly) [161], commonly referred to as endovanilloids because of their ability to activate TRPV1. Additionally, 2-arachidonoylglyceryl ether (noladin ether, 2-AGE), O-rachidonoylethanolamine (virodhamine), and arachidonoyl-L-serine (ARA-S) have also been identified [105].

Although still debated, NAEs are generally thought to be cannabinoid-receptor inactive, and they appeared to be responsible for enhancing AEA activity through the so-called "entourage effect", which consists in the inhibition of FAAH leading to an increase of AEA tissue levels [162].

PEA and OEA, shorter and fully saturated analogues of AEA, are well-documented high affinity PPAR- $\alpha$ and TRPV1 endogenous ligands and have been shown to exert roles in many physiological and pathological conditions such as satiety, inflammation, pain and memory consolidation [163-168]. Furthermore, due to their high expression in the CNS, growing evidence established their protective effects in neurodegenerative and neuropsychiatric disorders [169-172]. Moreover, PEA is also an endogenous agonist of GPR55, while OEA can bind GPR119.

As already mentioned, NADA belongs to the endovanilloid class of ECs and is an endogenous ligand of CB1, TRPV1 and PPAR- $\gamma$ [105]. Since this compound is widely distributed in the brain, particularly in the striatum, hippocampus, cerebellum, and dorsal root ganglia, it has been shown to exert a role in neuronal pain and inflammation [105]. Interestingly, NADA also showed antioxidative and anti-inflammatory effects on glial cells [105].

2-AGE is an endogenous analogue of 2-AG, able to bind to CB1, PPAR- $\alpha$ and very weakly to CB2 $[143,173]$. Moreover, thanks to its chemical structure, 2-AGE is more stable compared to AEA and 2-AG, which are rapidly hydrolysed in vivo [102].

Virodhamine is the ester of arachidonic acid and ethanolamine and is more expressed in the periphery compared to the brain, where it is rapidly converted to AEA, due to its chemical instability. Virodhamine has been shown to act as a full agonist of CB2 and a partial agonist of CB1, whereas at higher concentrations it can be also a CB1 antagonist [174]. Furthermore, it appeared to activate also PPAR- $\alpha$ [143] and GPR55 [175].

NAGly is an efficacious ligand of the orphan GPR18, with no CB1, CB2, or TRPV1 activity, and shows analgesic, anti-inflammatory, and vasorelaxant properties [176].

AraS is another ECs-like compound structurally similar to AEA, which was demonstrated to produce endothelium-dependent arterial vasodilatation and to activate p44/42 MAPKs in cultured endothelial cells, effects also observed after ECs treatment [105]. To date, AraS has been shown to be a low efficacy agonist to GPR18 without binding CB1/CB2 or additional ECs receptors [105].

Lastly, ODA is a full agonist of cannabinoid receptors with selectivity for the CB1, whose activation is the primary responsible for ODA effects [105].

As suggested by the wide range and distribution of the cannabinoid receptors and by the several compounds that take part in the ECS, the latter is now considered as a complex signaling system that may play a key role in physiological and pathological conditions. Thus, targeting these intricate pathways can represent a challenge in finding a therapeutic benefit for cannabinoid-based drugs in various disorders.

\section{Modulation of Oxidative Stress and Lipid Peroxidation through Cannabinoid Receptors by Endocannabinoids and Their Lipid Analogues}

It is well documented that there is an important cross-talk between the ECS and various redox-dependent processes. Indeed, the ECS has been reported as a novel therapeutic target against free radical-induced lipid peroxidation. In fact, it has been shown that ECS is implicated in the development 
of a growing number of diseases linked with redox homeostasis deregulation, including those associated with metabolic disorders, such as type 2 diabetes and obesity, cardiovascular diseases, as well as various neuropsychiatric and neurodegenerative disorders, ischemia/reperfusion (I/R) injury, and renal diseases $[2,4,5,54,177]$.

In the past decade, various and complex pathways have been studied to clarify the role of ECs in the modulation of redox imbalance, whose knowledge is the specific aim of this review.

There is accumulating evidence that shows the ability of ECs to alter the expression and/or the activity of enzymes implicated in the generation of these reactive small molecules (such as NOX2 and NOX4), and to modulate the production of cellular ROS/RNS by controlling mitochondrial-derived ROS/RNS generation [177].

Alternatively, ECs and their lipid analogues may modulate oxidative stress and lipid peroxidation either by conveying beneficial free radical scavenging effects or through targeting CB1 and CB2 [8-10]. Furthermore, $\mathrm{CB} 1$ and $\mathrm{CB} 2$ are differentially involved in oxidative stress modulation. In fact, several studies highlight that the activation of CB1 results in a redox imbalance enhancement, whereas CB2 stimulation is responsible for lowering ROS/RNS formation [9]. The beneficial or detrimental effects of ECs may be cell- and injury-type-specific and may depend on the stage of the disease progression as well [8].

This aspect was further investigated by Han and colleagues, who demonstrated a different role of CB1 and CB2 in regulating macrophage activity, and, in particular, the former appeared to be directly involved in the induction of intracellular ROS/RNS formation with consequent pro-inflammatory macrophage response, while the latter, after being activated by AEA, was able to negatively regulate CB1-stimulated ROS/RNS generation, through a pathway involving the small G protein, Rap1 [9]. The authors further showed that blocking CB1 while selectively activating CB2 might suppress pro-inflammatory responses of macrophages.

These data are consistent with other studies using cisplatin-induced renal dysfunction [178-181], in which it was observed that blocking the CB1 [179], or activating the CB2 [180,181], led to the attenuation of the cisplatin-induced increase of renal 4-HNE and ROS/RNS-generating enzymes (NOX2 and NOX4) expression, thus protecting against tubular damage.

Other examples of the opposite effects of CB1 and CB2 come from studies conducted in animal models of obesity and type 1 and 2 diabetes mellitus, where an increase of oxidative stress is observed [182-184]. In fact, in these models, increased levels of ECs in various renal cells contribute to the development of oxidative stress, as a result of renal CB1 activation, whereas inhibition of CB1 or activation of CB2 are able to ameliorate such effects (Figure 5) [185].

Overall, the over activation of the ECS that occurs in many type of tissue injury may induce oxidative stress, inflammatory cell infiltration, and the consequent cell death through CB1 activation [8,179], while it may also serve as an endogenous compensatory mechanism to limit early inflammatory response and interrelated oxidative stress-cell death through the activation of CB2 [186].

Interestingly, a cross-talk between redox homeostasis and ECS is particularly involved in the regulation of the cardiovascular system and metabolic tissues (i.e., liver, skeletal muscle and adipose tissue) $[187,188]$, where CB1 and CB2 are widely distributed. Furthermore, previous studies have suggested increased ECs levels in many cardiovascular disorders, such as cardiomyopathies, atherosclerosis, and hypertension [189]. 


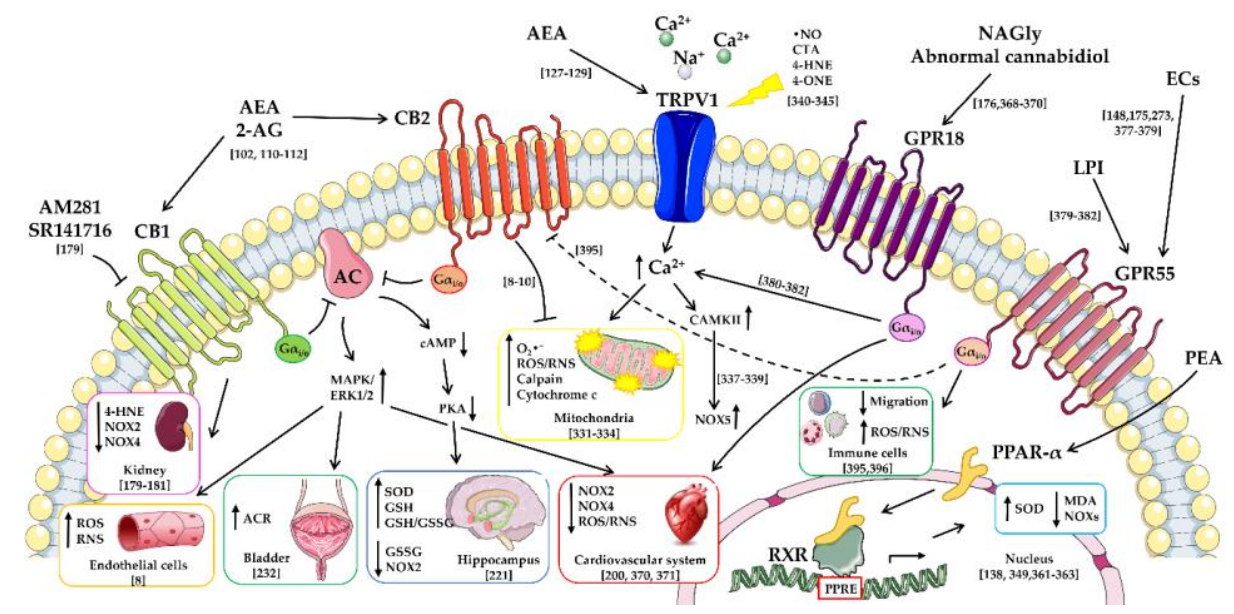

Figure 5. Role of endocannabinoids (ECs) and their lipid analogues in modulating reactive oxygen and nitrogen species (ROS/RNS) and reactive aldehydes formation. AM281: 1-(2,4-dichlorophenyl)-5-(4iodophenyl)-4-methyl-N-4-morpholinyl-1H-pyrazole-3-carboxamide; SR141716: rimonabant; CB: can nabinoid receptors; AEA: anandamide; 2-AG: 2-arachidonoyl-glycerol; TRPV: transient receptor potential vanilloid; CTA: crotonaldehyde; NAGly: N-arachidonoylglycine; GPR18: G proteincoupled receptor 18; GPR55: G protein-coupled receptor 55; LPI: L- $\alpha$-lysophosphatidylinositol; ECs: endocannabinoids; PEA: palmitoylethanolamide; PPARs: peroxisome proliferator-activated receptors; SOD: $\mathrm{Cu}^{2+} / \mathrm{Zn}^{2+}$-superoxide dismutase; MDA: malondialdehyde; PPRE: peroxisome proliferator response element; RXR: retinoid X receptor; NOX: NADPH oxidase enzyme; GSH: glutathione; GSSG: oxidized glutathione; ACR: acrolein; MAPK/ERK1/2: mitogen-activated protein kinases/extracellular signal-regulated kinases; PKA: protein kinase A; cAMP: adenosine $3^{\prime}, 5^{\prime}$-cyclic monophosphate; CAMKII: $\mathrm{Ca}^{2+} /$ calmodulin-dependent protein kinase; AC: adenylyl cyclase.

It is well known that cardiovascular diseases are associated with oxidative stress, which leads to the accumulation of lipid peroxidation-derived reactive aldehydes and may consequently cause an increase in the formation of ROS/RNS and/or a decrease in the antioxidant defense [2].

In this regard, it has been demonstrated that, after being activated by AEA, CB1 expressed in endothelial cells [190] and in cardiomyocytes in a murine model of doxorubicin-induced cardiomyopathy [8], induce the activation of the p38-JNK-MAPK pathway and increase the generation of ROS/RNS. These effects lead to cell death and resulted to be partially attenuated by the pharmacological inhibition of CB1 [9].

In contrast to CB1, the activation of CB2 appeared to exert cardioprotective effects by reducing $\mathrm{O}_{2} \bullet-$ production and decreasing endothelial cell activation. These findings are in agreement with recent studies showing that CB2 activation, by ECs and their analogue lipid mediators, protects against oxidative stress-induced tissue damage in experimental models of I/R injury [191-195], cardiovascular inflammation, and/or atherosclerosis [191,196,197].

Among the cardiovascular diseases, atherosclerosis is due to altered homeostatic redox processes with progressive ROS/RNS over production, which leads to the generation and deposition of toxic oxidized low-density lipoproteins (oxLDL) in the vessel wall. It has been clearly demonstrated that OxLDL promote the activation of NOXs and the synthesis of $\mathrm{O}_{2} \bullet^{-}$by a cluster of differentiation 36 (CD36) scavenger receptor-mediated method, effects that can be counteracted by several compensatory mechanisms including the involvement of the ECS [198].

Support for this comes from the observation that increased production of $\mathrm{O}_{2} \bullet^{-}$and enhanced NOXs activation in atherosclerosis correlated with increased rates of 2-AG biosynthesis in the vessel wall, which may be a compensatory response to oxidative stress via CB2 signaling [199].

In agreement with these results, it has been observed that the genetic disruption of CB2 in Apolipoprotein E-deficient mice $\left(\mathrm{ApoE}^{-/-}\right)$, a murine model of atherosclerosis, is the cause of 
boosted $\mathrm{O}_{2} \bullet^{-}$generation, whereas its stimulation reduced vascular $\mathrm{O}_{2} \bullet^{-}$release, resulting in the suppression of ROS/RNS generation and a subsequent reduction in the size of atherosclerotic lesions (Figure 5) [200].

Further evidence of the protective effects of ECs in atherosclerosis comes from the demonstration that $\mathrm{CB} 1$ inhibition in $\mathrm{ApoE}^{-/-}$mice is able to promote the down-regulation of vascular angiotensin II type 1 receptor (AT1), which is responsible for NOXs activation when stimulated by angiotensin II [201]. Consequently, the decreased expression of AT1, mediated by CB1 inhibition, leads to the reduction of NOXs activity and oxidative stress, thereby improving endothelial function and exerting beneficial direct vascular effects [201].

Since the discovery that the levels of NAEs are higher in several pathological conditions linked with redox homeostasis impairment, these compounds are attracting great attention as a survival response toward oxidative damage [202].

Indeed, it has been clearly shown that NAEs, particularly 16:0 and 18:0, exert protective effects in many diseases by the inhibition of free radical-induced lipid peroxidation [203], which is considered one of the main causes of cell damage and death [204].

In particular, previous findings discovered an involvement of two long-chain NAEs, PEA and SEA, in the inhibition of lipid peroxidation in liver mitochondria membranes of acute hypoxic hypoxia animal model [203], a pathological condition associated with an increase in partially reduced oxygen products, which represent the main cause of lipid oxidation-induced formation of reactive aldehydes [205]. The authors suggested that the inhibitory effect of NAEs on lipid peroxidation depends on the length of acyl chain and is related to their ability to protect membranes [206].

These results are in good agreement with other data showing that OEA treatment of rat heart mitochondria is able to reduce the production of MDA, which is one of the end products of lipid peroxidation in cell membrane [203].

Among NAEs, OEA, PEA, and AEA appeared to inhibit $\mathrm{Cu}^{2+}$-induced in vitro lipid peroxidation in plasma lipoproteins [202] and cardiac mitochondria [207], consequently showing antioxidant properties in the pathogenesis of atherosclerosis. Moreover, Zolese and collaborators demonstrated that, depending on its concentration of incubation, PEA exerts both anti-oxidative and pro-oxidative effects on radical-induced oxidation of plasma LDL [208]. The authors showed that higher PEA concentrations could be responsible for its pro-oxidant effect, whereas PEA at lower levels is able to suppress reactive aldehydes, generated by lipid peroxidation, and to decrease the consumption rate of LDL endogenous anti-oxidants, thereby showing anti-oxidant properties [208].

In the context of cardiovascular diseases is also interesting to mention hypertension, which is characterized by (1) deregulation of ECS with increased activity of FAAH and MAGL, (2) increased levels of AEA, 2-AG, and NADA, and (3) increased expression of CB1 [209], effects that are accompanied by an imbalance of redox homeostasis (decreased activities of glutathione peroxidase (GPx), glutathione reductase (GR) and the antioxidant enzymes $\mathrm{Cu}^{2+} / \mathrm{Zn}^{2+}$-superoxide dismutase (SOD) and catalase (CAT)).

It has been demonstrated that increased levels of AEA, following chronic administration of the FAAH inhibitor URB597 in a rat model of hypertension [210], significantly enhanced the expression of the CB1, thus preventing the hypertension-induced decrease of SOD, glutathione (GSH) and glutathione transferase (GT) activities and consequently lowering ROS generation and inducing hypotension. However, it has been postulated that the enhanced AEA levels are responsible for the perturbation of membrane phospholipid metabolism resulting in PUFAs chain cyclization or fragmentation. This causes an increase in the formation of $\alpha, \beta$-unsaturated reactive aldehydes such as 4-HNE, MDA, and 4-ONE in the liver of hypertensive rats [209].

It is well documented that ECS and oxidative stress may also play a role in the pathophysiology of liver diseases [188,211]. For instance, DeLeve and collaborators [212] reported that CB1 activation is responsible for liver inflammation and, therefore, induces non-alcoholic liver disease, 
whereas the CB2 stimulation appeared to have protective effects in liver damage through reducing liver oxidative stress [213].

Accumulating evidence supports the involvement of ECS as a therapeutic potential in many neurodegenerative pathologies such as Alzheimer's and Parkinson's diseases, in which oxidative stress has been recognized as one of the hallmarks of the pathology [4,171,172,214-217].

Indeed, the brain is a tissue with a high oxygen consumption whose cell membranes are particularly rich in PUFA side-chains and, therefore, highly sensitive to lipid peroxidation and oxidative damage $[54,183,218]$.

NOXs enzymes have been shown to be significant sources of ROS/RNS during tissue injury and, in particular, it has been observed that the activation of NOX2 contributes to oxidative imbalance-induced CNS damage [219], while its inhibition is able to ameliorate cerebral oxidative stress injury [220].

A recent study conducted by Jia and collaborators defined AEA as a promising candidate for the treatment of oxidative stress-related neurological disorders [221]. In particular, AEA has been found to protect a mouse hippocampal neuron cell line from $\mathrm{H}_{2} \mathrm{O}_{2}$-induced redox imbalance by increasing SOD and GSH intracellular levels, reducing oxidized glutathione (GSSG), increasing the GSH/GSSG ratio, and lowering NOX2 expression. All of these effects were completely abolished by both CB1 antagonist administration and CB1-siRNA, suggesting that the ability of AEA to ameliorate oxidative stress in hippocampal neurons may be mediated by CB1 activation (Figure 5) [221].

Similarly, it has been also reported that the stimulation of CB1 is able to reduce intracellular ROS/RNS generation and NOX2 expression thus enhancing nigrostriatal dopaminergic neurons survival in a mouse model of Parkinson's disease [222].

These findings supporting the beneficial effects of CB1 activation against ROS/RNS formation in the brain seem to be controversial in comparison to what above mentioned for the cardiovascular and renal tissues. An explanation for this argument comes from growing evidence suggesting that the pathways underlying the interplay between cannabinoid receptors and oxidative stress modulation may be cell type-specific [177].

Notably, as well as responses mediated by CB1, further data showed that the modulation of CB2 signaling, either by using specific CB2 agonists [223-225] or by inhibiting 2-AG degrading enzyme MAGL [226], can ameliorate the morphological changes induced by oxidative stress and attenuate cerebral $\beta$-amyloid plaque accumulation in a mouse model of Alzheimer's disease carrying mutated human APPswe and PS1dE9 genes [227,228].

Interestingly, in vitro studies revealed that a selective CB1 agonist, arachidonyl-2-chloroethylamide, decreased the $\mathrm{Fe}^{2+}$-induced lipid peroxidation in the brain, through a metal-chelating mechanism, as well as the $\bullet \mathrm{OH}$ radicals generated by the Fenton system [229].

Moreover, the activation of the recently discovered mitochondrial CB1 by arachidonyl-2-chloroethylamide has been demonstrated to reduce oxidative stress, thereby exerting neuroprotective effects in $I / R$ injury [227]. To this regard, CB2 activation also appeared to have a role in attenuating I/R damage through lowering ROS/RNS production and lipid peroxidation [227].

The involvement of CB2 in I/R injury has also been investigated in a context of propofol cardioprotection in an in vivo model of myocardial I/R injury, in which it has been observed that CB2 inactivation reverses propofol cardioprotective and anti-oxidative effects [230]. These findings imply that the enhancement of ECs release and the subsequent activation of CB2 signaling are responsible for the reduced oxidative stress mediated by propofol cardioprotection in myocardial I/R injury [230].

Furthermore, CB2 are expressed in the bladder [231] and are involved in the treatment of hemorrhagic cystitis, a common side effect of Cyclophosphamide, an antineoplastic alkylating agent usually metabolized by the liver to ACR, which is accumulated in urine and therefore is considered to be the main responsible for Cyclophosphamide-induced cystitis [232]. The findings of this study 
revealed that, following stimulation, $\mathrm{CB} 2$ attenuated ACR-induced cystitis through modulating ERK1/2 MAPK pathways (Figure 5) [232].

AEA and 2-AG are also involved in the progression of cancer, where they were shown to exert protective effects against increased ROS/RNS production-induced tumor [233], leading to apoptosis in normal and cancer cells by modulating ERK and ROS/RNS pathways [234].

\section{Modulation of Oxidative Stress and Lipid Peroxidation through the Transient Receptor Potential Vanilloid Channels by Endocannabinoids and Their Lipid Analogues}

The transient receptor potential (TRP) channels superfamily is a wide group of tetrameric channels formed by six transmembrane domains and a cation-selective pore. On the basis of its amino acid sequence homology, TRP superfamily, in mammals, is organized into six subfamilies, which include TRP canonical, TRP melastatin, TRP ankyrin, TRP mucolipin, TRP vanilloid, and TRP polycistin channels. TRP channels are ubiquitously expressed in most mammalian cells $[235,236]$ and they depolarize cells by altering membrane potential or intracellular $\mathrm{Ca}^{2+}$ concentration. With the exception of some TRP channels, most of them are non-selective and weakly voltage-sensitive [237]. TRP channels are fundamental players of sensory physiology as they respond to environmental stimuli such as taste, light, sound, smell, touch, temperature, and osmolarity [238]. Today, only a few endogenous ligands are known to activate TRP channels, and it is not yet clear how they are activated in vivo [237]. However, several experiments performed on knockout mice are revealing the complexity and the different functions of TRP channels [238-240].

In this review, we will focus mainly on the vanilloid TRP (TRPV) channels subfamily and how they respond to oxidative stress and lipid peroxidation-induced cell damage. Currently, six TRPV channels (TRPV1-6) have been identified and divided into two subgroups: TRPV1-4 and TRPV5-6, based on their amino acid sequence, functions, and cation selectivity. A detailed review on TRPV channels pharmacology has been provided by Vriens and colleagues [241]. Briefly, TRPV1 is expressed in primary sensory neurons, in few brain regions (hypothalamus, intrafascicular, supramammillary and rostral raphe nuclei, entorhinal cortex, hippocampus, and periaqueductal gray), as well as in smooth muscle cells of several thermoregulatory tissues (skin, dura, tongue, trachea, cremaster muscle, and ear) [242]. TRPV1 seem to be activated by heat above $43{ }^{\circ} \mathrm{C}$, by low $\mathrm{pH}$ [243-245], by vanilloid compounds (e.g., capsaicin and capsinate) $[243,246]$, by ethanol $[247,248]$, as well as by several endogenous compounds such as AEA [127], OEA [249], NADA [250], N-oleoyldopamine (OLDA) [251], and arachidonic acid-derived metabolites released by LOXs [252]. Moreover, TRPV1 activity is modulated by various intracellular molecules and signals including calmodulin [253,254], ATP [255], phosphatidylinositol 4,5-bisphosphate (PIP2) and phosphatidylinositol 3,4,5-trisphosphate (PIP3) [256], PKC [257], PKA [258], as well as protein phosphatase calcineurin [259].

Among the main functions, in addition to acting as a thermoreceptor, TRPV1 regulates the normal functioning of urinary bladder [260], controls the gut afferent sensitivity to distension and acids [261] and it also allows the taste perception of sodium chloride [262]. From a physiopathological point of view, TRPV1 has a direct role in the behavioral response to ethanol $[247,248,263]$, as well as in inflammatory airway diseases [264]. Moreover, TRPV1 is also involved in vascular dementia as well as in Huntington's disease, where its activation promotes neuroprotection, increase learning and memory, and reduce oxidative stress [265-267].

Differently, TRPV2 is a weakly $\mathrm{Ca}^{2+}$-selective channel, which seems to be activated by thermal stimuli above $53{ }^{\circ} \mathrm{C}$ but not by low $\mathrm{pH}$ or vanilloid compounds [268]. TRPV2 is expressed in different tissues including brain, spinal cord, spleen, and intestine, as well as in vas deferens, bladder, heart, kidney [269], and immune cells such as monocytes and dendritic cells [270]. It is noteworthy that TRPV2 signaling plays an important role in the endosomal pathway, where TRPV2 modulates the fusion between endosomal membranes by releasing $\mathrm{Ca}^{2+}$ from early endosomes $[271,272]$ as well as in phagocytosis [273,274]. 
TRPV3 is a non-selective cation channel activated by temperatures of $33-39^{\circ} \mathrm{C}$, which showed a marked sensitization following repeated heat stimuli $[275,276]$. Moreover, TRPV3 could be activated by several vegetable-derived molecules, such as eugenol, thymol, camphor and carvacrol [277,278]. Furthermore, other agents such as PIP2/PIP3, calmodulin, ATP, and inflammatory mediators like histamine, bradykinin, and PGE2 are able to sensitize TRPV3 function [278-281]. Moreover, it was hypothesized that, in rodent skin cells, heat-induced TRPV3 signaling could mediate an autonomous response to heat stimulation, thus acting as thermoreceptors in keratinocytes [275,282]. In support of this evidence, TRPV3 knock-out mice showed strong deficits in response to heat stimulation [277]. Likewise, TRPV4 is also activated by heat, in particular by temperatures of $27-34{ }^{\circ} \mathrm{C}$, as well as by osmotic and mechanical stimuli $[283,284]$. Among putative endogenous ligands, it was observed that AEA, 2-AG, and arachidonic acid indirectly activate TRPV4 by epoxyeicosatrienoic acids released from cytochrome P450 epoxygenases [285,286]. As for TRPV1 and TRPV3, TRPV4 activity is modulated by PIP2/PIP3, calmodulin and ATP [287-289] and by several protein kinases, such as PKA, PKC, Src family kinases (SFKs), and serum glucocorticoid-induced protein kinase-1 (SGK1) [290-293]. TRPV4 channels are widely expressed in epithelial cells of the renal convoluted tubule, trachea, submucosal glands, as well as in neutrophils, in autonomic nerve fibers, in peripheral sensory ganglia, in hair cells of the inner ear, and brain structures such as vascular organ of the lamina terminalis and the hypothalamic median preoptic region [283,294,295]. Due to its widespread expression, TRPV4 is involved in several physiological functions. In particular, it mediates temperature sensation in skin keratinocytes, anterior hypothalamus, and sensory ganglia $[275,283,284]$. TRPV4 is also involved in mechanosensation [296] and contribute to the normal functioning of the urinary bladder [297,298] and pulmonary alveoli $[299,300]$ and to the development of mechanical hyperalgesia in inflammatory states [301].

TRPV5 and TRPV6 share a high sequence homology (74\% of identity) and form highly $\mathrm{Ca}^{2+}$-selective channels, which are not activated by heat [302-304]. As for the other TRPV family members, the activity of TRPV5 and TRPV6 is modulated by a variety of second messengers, including $\mathrm{Ca}^{2+}, \mathrm{Mg}^{2+}$, ATP, PIP2, calmodulin, and PKC [302,303,305-313]. TRPV5 is expressed in several tissues but is mostly abundant in renal tubules, where it regulates transcellular transport and reabsorption of $\mathrm{Ca}^{2+}$ [314]. Furthermore, TRPV5 is also involved in bone remodeling [315,316]. TRPV6 is widely expressed $[305,317,318]$ but is mostly distributed in the intestine, kidney, and placenta, where it respectively modulates the $\mathrm{Ca}^{2+}$ transcellular entry, reabsorption, and transfer to fetus [319-322].

Among endogenous ligands of TRPV, or endovanilloids, there are leukotriene B4 and 12-hydroperoxyeicosatetraenoic acid that belong to the eicosanoid family, produced by lipoxygenase-mediated oxidation of PUFAs (especially arachidonic acid), which are potent activators of TRPV1 [252,323]. Other lipid-derived mediators of TRPV are epoxyeicosatrienoic acids, such as $5^{\prime}, 6^{\prime}$-epoxyeicosatrienoic acid, which are synthesized from arachidonic acid by cytochrome P450 epoxygenases and may activate TRPV1 and TRPV4 [286,324].

As AEA is structurally similar to arachidonic acid as well as to PUFAs, it can be metabolized by COX-2 and LOXs. In particular, COX-2 converts AEA into prostaglandin-ethanolamides, which are endoperoxide molecules also known as prostamides [325,326]. On the other hand, LOXs convert AEA into hydroperoxy fatty acids, such as 12- and 15-hydroperoxyeicosatetraenoylethanolamide, which are, respectively, synthesized by 12-LOX and 15-LOX [327,328]. In guinea-pig bronchi, these oxidized lipid mediators seem to act as TRPV1 agonists and are also responsible, at least partially, for the contractile action of AEA [329].

Growing evidence supports a key role for TRPV, especially TRPV1, in the modulation of oxidative stress and lipid peroxidation mediated by endocannabinoids, their lipid analogues, and other lipid-related mediators. As known, AEA is considered an endovanilloid because of its ability to activate TRPV1 [127,136,330]: several in vitro analyses performed on human and rat cell lines have shown that AEA induces apoptotic effects via a TRPV1-mediated mechanism, which induces and increase in intracellular $\mathrm{Ca}^{2+}$ levels, mitochondrial uncoupling, oxidative stress due to increased $\mathrm{O}_{2} \bullet-$ formation, 
cytochrome c release as well as calpain and caspase-3 activation [331-333]. Similarly, another in vitro study performed on human bladder cancer T24 cells showed that TRPV1 activation by capsaicin was correlated in a dose-dependent manner with an increase of cytosolic $\mathrm{Ca}^{2+}$ levels, with mithocondrial membrane depolarization and a marked ROS/RNS generation, which reduced T24 cells viability (Figure 5) [334].

Other studies showed that AEA was able to increase ROS/RNS production by targeting TRPV1, [335,336], which lead to the activation of the $\mathrm{Ca}^{2+} /$ calmodulin-dependent protein kinase II (CAMKII), and to the upregulation of NOX5 [337-339].

Moreover, it was observed, in the human esophageal epithelial cell line Het1A, that acidor capsaicine-induced activation of TRPV1 leads to an increased production of intracellular ROS/RNS levels as well as to increased ROS/RNS- or HNE-modified proteins. In the same study, immunoprecipitation analyses of 4-HNE-stimulated Het1A cells revealed, also, that TRPV1 was modified by 4 -HNE [340]. In addition to 4 -HNE, TRPV1 is directly activated by $\bullet N O$, oxidants and other chemical agents through the modification of cysteine free sulfhydryl groups [341]. Moreover, functional assays with mutated TRPV showed that cysteine residues 553 and 558, between the fifth and sixth transmembrane domains, are essential for $\bullet$ NO-induced activation of TRPV1, TRPV3, and TRPV4 and thus are potential targets of nitrosylation [342]. In addition, TRPV1 nitrosylation by $\bullet N O$ increased the intracellular $\mathrm{Ca}^{2+}$ levels and thus enhanced the channel sensitivity to $\mathrm{H}^{+}$and heat. These sensitizing effects induced by nitrosylation of cysteine residues were further supported by the use of oxidizing agents such as diamide and chloramine-T [343]. Furthermore, several studies reported that TRPV1 is also responsive to other electrophilic compounds generated during oxidative stress. To this regard, in TRPV1 channel-expressing human embryonic kidney (HEK) cells, a modest TRPV1 activation was observed following 4-ONE treatment $(100 \mu \mathrm{M})$ [344]. Another TRPV1 activator is CTA. In particular, an in vitro study performed on murine cardiomyocytes incubated with CTA showed an increase in TRPV1 and NOXs levels, in ROS/RNS formation, in apoptotic events, and a decrease in the activity of mithocondrial proteins such as aconytase, uncoupling protein 2 , and peroxisome proliferator-activated receptor-gamma coactivator-1alpha [345].

\section{Modulation of Oxidative Stress and Lipid Peroxidation through the Peroxisome Proliferator-Activated Receptors-Alpha by Endocannabinoids and Their Lipid Analogues}

Because of the high expression of PPAR- $\alpha$ in kidney, liver, heart, and brain, it is well documented that the activation of these transcription factors exerts protective roles in cardiovascular as well as renal, hepatic, and neurodegenerative diseases [138,346-349].

There is rising acknowledgment that the beneficial effects of PPAR- $\alpha$ stimulation could be explained by its ability to dampen oxidative stress in several pathological conditions linked to the redox impairment. A number of reports point to the involvement of various mechanisms through which PPAR- $\alpha$ agonists can modulate antioxidants.

In particular, the identification of PPREs elements in promoter regions of CAT and SOD genes in rat [347] additionally supported the involvement of these nuclear receptors in lowering ROS/RNS formation and lipid peroxidation products.

Nevertheless, PPAR- $\alpha$ is not only involved in suppressing ROS/RNS generation, but it can also play a role in modulating enzymes involved in ROS/RNS synthesis and/or scavenging. Consistently, the decrease in striatal SOD expression, which resulted in the 6-hydroxydopamine (6-OHDA)-induced Parkinson disease mouse model, was completely counteracted by PPAR- $\alpha$ agonists confirming the ability of this nuclear receptor to regulate the transcription of antioxidant enzymes (Figure 5) [138,346,350].

For instance, Diep and colleagues reported that the PPAR- $\alpha$-induced suppression of oxidative stress in cardiovascular diseases is mediated by the ability of PPAR- $\alpha$ activators to inhibit angiotensin II-induced activation of NOXs in the vascular wall [348] and to increase scavenging enzymes as well. 
Among the PPAR- $\alpha$ ligands, ECs and their lipids analogues have been shown to play a prominent role in affecting redox homeostasis in several oxidative stress-related pathologies, through a PPAR- $\alpha$ dependent mechanism. Consistently, it has been shown that PPAR- $\alpha$ stimulation by PEA lowers blood pressure and prevents hypertension-induced renal damage in hypertensive rats by inhibiting the subunit p47phox of NOXs (a key regulatory subunit essential for NOXs functioning) [349], and by significantly reducing the hypertension-induced increased levels of MDA in urine and renal tissues (Figure 5) [348].

Moreover, through PPAR- $\alpha$ activation, PEA appeared to simultaneously enhance the antioxidant defense by increasing SOD expression in the kidney [348], thus protecting from renal damage. In agreement with these results, other studies further support the potential beneficial effects of PEA activated-PPAR- $\alpha$ on kidney diseases [351]. For instance, it has been demonstrated that PEA, by targeting PPAR- $\alpha$, is able to prevent kidney damage induced by $I / R$ injury through dampening the lipid peroxidation products in the kidney, thereby leading to a reduction of neutrophil recruitment [352].

Moreover, because of the high expression of PPAR- $\alpha$ and its endogenous lipid agonists in the CNS, it has been demonstrated that PPAR- $\alpha$ activation can exert neuroprotective properties in several neuropathological conditions, especially in neurodegenerative disorders [169], by modulating the redox balance that resulted altered in these situations.

Further support for this comes from the observation that the brain areas that display the highest PPAR- $\alpha$ expression exhibit an overlapping expression pattern with key enzymes involved in ROS/RNS synthesis and/or scavenging including CAT, SOD1 and acyl-CoA oxidase 1 (ACOX1) [353-355], whose genes are known to be under the control of PPAR- $\alpha$ [356,357].

Thanks to its anti-oxidative properties, PPAR- $\alpha$ protects against normal brain aging and regulates the onset and progression of neurodegenerative disorders [358,359]. Interestingly, evidence suggests that in conditions of neurodegeneration, oxidative stress itself is responsible for the induction of PPAR- $\alpha$ expression. As a matter of fact, in hippocampal CA1 pyramidal cells of a transgenic mouse model of Alzheimer's disease, an increase in the levels of PPAR- $\alpha$ simultaneously with the production of ACR and 8-hydroxy(de)oxyguanosine, which represent markers of oxidative imbalance, was observed [360]. Such increase in hippocampal PPAR- $\alpha$ expression could trigger the induction of its target genes encoding for peroxisomal membrane protein-70 (PMP70) and ACOX1, which are involved in fatty acyl-CoA transport across peroxisomal membranes and peroxisomal $\beta$-oxidation respectively, by evoking a compensatory response to $A \beta$-mediated mitochondrial insult that occurs in early stage of Alzheimer's disease [4-6,360].

In this context, PEA was demonstrated to protect neurons and glia from oxidative stress by reducing MDA formation, thereby restoring a proper cellular redox state, and this effect appeared to be PPAR- $\alpha$-dependent $[171,172,361,362]$. It has also been established that PEA neuroprotective effects are mediated, at least in part, through the de novo synthesis of neurosteroids (particularly allopregnanolone), which is triggered by PPAR- $\alpha$ activation [362].

The abovementioned findings, coupled with a recent report demonstrating that PEA treatment (through binding PPAR- $\alpha$ ) is able to induce SOD and dampen ROS/RNS-induced oxidative damage in 6-OHDA-induced mouse model of Parkinson disease, additionally suggest the neuroprotective scavenging effects of this lipid compound (Figure 5) [363]. Beyond the ECs, several other synthetic ligands of PPAR- $\alpha$ have been shown to exert antioxidative properties. For instance, Wy14643 through binding PPAR $\alpha$ is able to protect rabbit hearts from I/R injury by increasing the expression of the oxidative stress-inducible isoform of heme oxygenase and to preserve hippocampal neurons from $\mathrm{H}_{2} \mathrm{O}_{2}$ challenge by modulating mitochondrial fusion and fission events [360].

Moreover, it should be noted that the production of PPAR- $\alpha$ endogenous ligands, PEA and OEA as the mostly characterized, could be differently affected by physiological and pathological oxidative stress-related conditions. For instance, the ROS/RNS metabolism imbalance, which is responsible for oxidative stress-induced brain aging and neurodegeneration, can quantitatively and qualitatively 
modify the production of PPAR- $\alpha$ agonists and thus differently modulate PPAR- $\alpha$-mediated pathways in neuronal and astroglial cells [169].

Additionally, the interplay between PPAR- $\alpha$ and oxidative-stress-induced lipid peroxidation comes also from the observation that NOXs activated-4-HNE is able to act as an endogenous PPAR- $\alpha$ activator leading to the discovery of the so called "lipid peroxidation products-PPARs-NOXs axis" [364]. The regulation of this axis, which represents an alternative pathway mediating ROS/RNS production, could ensure additional strategies to counteract oxidative-stress-related disorders.

\section{Modulation of Oxidative Stress and Lipid Peroxidation through Other Receptors by Endocannabinoids and Their Lipid Analogues}

Recently, in addition to PPAR- $\alpha$ and TRPV1, the orphan receptors GPR18, GPR55 and GPR119 were assessed as novel cannabinoid-related receptors [365]. Structurally, GPRs are GPCRs and, among them, GPR18, GPR55 and GPR119 share a limited primary sequence homology with $\mathrm{CB} 1$ and $\mathrm{CB} 2$.

GPR18 was discovered for the first time in 1997 by Gantz and colleagues [366]. GPR18 is widely expressed in testis and spleen, and in lesser extent in several other tissues such as thymus, lymph nodes, peripheral blood leukocytes, small intestine, and appendix, thus suggesting a regulatory role for GPR18 in the immune system [366]. Moreover, GPR18 was also found in several brain regions such as hypothalamus, brainstem, cerebellum, and striatum as well as in lung, thyroid and ovary [367]. Several studies reported that NAGly is the endogenous ligand of GPR18 that induces an elevation of intracellular $\mathrm{Ca}^{2+}$ levels [176]. The same authors demonstrated also that GPR18 activation was pertussis toxin-sensitive, suggesting the involvement of a $G_{\alpha i / o}$ protein in this response [176]. Despite these first evidence, several authors reported variable responses of GPR18 following the administration of NAGly [368,369].

For the first time Penumarti and colleagues demonstrated that GPR18 is expressed in the rostral ventrolateral medulla of rats and exerts tonic restraining influence on blood pressure [370]. In particular, authors observed that the systemic administration of abnormal cannabidiol, a synthetic agonist of GPR18, induced a dose-dependent reduction of blood pressure and increased heart rate. In addition, GPR18 activation increased neuronal adiponectin and $\bullet N O$, and finally reduced neuronal ROS/RNS levels. These findings suggested for the first time a sympathoinhibitory role of GPR18 (Figure 5) [370].

More recently, another study confirmed that chronic GPR18 activation with its agonist abnormal cannabidiol produced hypotension, suppressed the cardiac sympathetic dominance, and improved left ventricular function in conscious rats [371]. In the same study, ex vivo analysis of plasma, heart, and vascular tissues of treated rats revealed an increase in cardiac and plasmatic adiponectin levels, an increase in aortic eNOS expression, augmented levels of vascular and serum $\bullet \mathrm{NO}$, high levels of myocardial and plasmatic guanosine $3^{\prime}, 5^{\prime}$-cyclic monophosphate (cGMP), an increase of myocardial Akt and ERK1/2 phosphorylation, and, more importantly, reduced myocardial ROS/RNS formation [371]. These results suggest a protective role of GPR18 in cardiovascular diseases, in particular highlights the possibility to consider GPR18 as a viable molecular target for developing new antihypertensive drugs which are able to improve also the cardiac function.

Human GPR55 receptor was identified for the first time in 1999, through in silico studies, and was subsequently cloned [372]. GPR55 receptor is widely expressed, and therefore its activity was correlated with multiple physiological processes. In particular, GPR55 is expressed in the frontal cortex, striatum, hippocampus, hypothalamus, cerebellum, and brainstem [372,373]. Moreover, GPR55 was also found in peripheral organs and cells such as dorsal root ganglion [148], spleen, adrenal glands, jejunum, ileum [373], pancreas [374], bones [375] and microglia [376]. The GPR55 pharmacology and its downstream signaling are not yet certain. Nevertheless, some authors reported that ECs such as AEA, 2-AG, and virodhamine can activate both etherologous and native GPR55-expressing cells $[148,273,377]$, while other groups reported that ECs are weak ligands [378,379], may act as partial agonists [175], or are not able to activate GPR55 receptors [380,381]. Another open debate regards 
the ability of PEA to activate [373] or not the GPR55 receptors [148,382]. Despite the controversial results about the ability of ECs to activate GPR55, it is well accepted that the endogenous lipid L- $\alpha$-lysophosphatidylinositol (LPI) and its analogue 2-arachidonoyl-sn-glycero-3-phosphoinositol are endogenous ligand of GPR55 [379-382]. However, it is necessary to specify that LPI is not selective only for GPR55 [383]. Moreover, GPR55 may also heterodimerize with other receptors, such as CB2 [384], thus further confounding the results obtained so far.

About the mechanisms of downstream signaling, GPR55 activation was associated with an increase of intracellular $\mathrm{Ca}^{2+}$ levels, with the activation of RhoA and ERK1/2 pathway, and with the activation of several transcription factors, such as the nuclear factor of activated T-cells and the cAMP response element binding protein (CREB) [380,382].

The human orphan receptor GPR119 was identified for the first time in 2003 by sequence alignment tools analysis [385]. GPR119 is expressed mainly in pancreas and gut, in particular in $\beta$-cells and pancreatic polypeptide-producing PP cells, where its activity modulates the glucose-dependent insulin secretion [386,387], as well as in enteroendocrine L-cells, where it regulates the secretion of glucagon-like peptide 1 [388,389]. GPR119 is also expressed in liver [390] and skeletal muscle [Cornall et al., 2013]. In normal-weight and healthy patients it was observed that gut GPR119 expression rapidly increased following acute fat exposure [391], thus suggesting a potential involvement of GPR119 in type 2 dyabetes, metabolic disorder, and obesity.

The main endogenous ligands of GPR119 are, in order of potency, OLDA, OEA, PEA, and AEA [392,393]. Other endogenous GPR119 agonists are 2-oleoylglycerol [394] and oleoyl-lysophosphati dylcholine [386]. Clearly, also in this case, further studies are required to better characterize the pharmacological profile of GPR119.

Increasing evidence suggests that ECs may regulate ROS/RNS levels and thus reactive aldehydes formation by targeting GPR55. In this regard, Balenga and colleagues showed that GPR55 activity modulates RhoA-dependent neutrophil migration, and it may prevent oxidative damage [395]. In particular, this study, performed on neutrophils, demonstrated that 2-AG-induced ROS/RNS production, which was mediated by a CB2-dependent mechanism, appeared to be significantly decreased following the co-treatment with the GPR55 agonist LPI [395]. This negative interaction between GPR55 and CB2 was observed during neutrophil respiratory burst. Therefore, after an initial synergism in inducing chemotaxis, GPR55 and CB2 disengaged and, by a functional repression, GPR55 decreased CB2-induced oxidative damage by blocking CB2 downstream signaling [395]. Conversely, a recent study performed on human natural killer cells and monocytes unveiled a proinflammatory role of GPR55 activation (Figure 5) [396], which could be potentially correlated with an increase of ROS/RNS production and thus with oxidative stress.

\section{The Role of Antioxidant System as Scavenger of ROS/RNS and Reactive Aldehydes}

The "endogenous antioxidant system" relies on several enzymes, peptides, cofactors, and other molecules that are essential for the maintenance of a physiological redox homeostasis. Overall, endogenous antioxidants may be divided into two main groups, formed by enzymatic and non-enzymatic antioxidants [6,397]. The enzymatic group include CAT [398], SOD [399,400], GPx, GR, GT [401], thioredoxin (Trx) and thioredoxin reductase (TrxR) [402] while the non-enzymatic group include several antioxidant molecules such as GSH, GSSG, [403], vitamin A (retinol) [404], vitamin C (L-ascorbic acid) [405], vitamin E (tocopherols) [406], coenzyme Q10 (CoQ10) [407], carotenoids [408], flavonoids, polyphenols [409-411], minerals such as $\mathrm{Se}^{2+}$ [412], $\mathrm{Cu}^{2+}$, and $\mathrm{Zn}^{2+}$ [413], as well as metabolites such as uric acid, bilirubin [414] and melatonin [415], which also possess antioxidant properties.

Briefly, CATs are $\mathrm{Cu}^{2+} / \mathrm{Zn}^{2+}$-dependent enzymes present in peroxisomes that catalyze the conversion of $\mathrm{H}_{2} \mathrm{O}_{2}$ in water and oxygen [398]. Among SOD enzymes, cytolosic SOD are $\mathrm{Cu}^{2+} / \mathrm{Zn}^{2+}$-dependent enzymes, while mitochondrial SODs are $\mathrm{Mn}^{2+}$-dependent enzymes that metabolize $\mathrm{O}_{2} \bullet-$ into $\mathrm{H}_{2} \mathrm{O}_{2}$ and oxygen. Therefore, SOD represents the first line of defense against 
reactive aldehydes formation [400]. GPx, GR and GT are $\mathrm{Se}^{2+}$-dependent enzymes that, together with GSH and GSSG, constitute the glutathione system, which contributes to eliminate $\mathrm{H}_{2} \mathrm{O}_{2}$ and other reactive molecules [403]. Similarly, Trx, TrxR, and NADPH constitute the thioredoxin system, which is critical for redox regulation of protein function and signaling via thiol redox control [402].

Vitamin $A$ is produced in the liver, derives from $\beta$-carotene and acts as a lipid peroxidation blocker by preventing the chaining process in the propagation phase [404]. Similarly, also vitamin E acts as a lipid peroxidation blocker by donating a hydrogen atom to peroxyl radicals, thus forming tocopheroxyl radicals which are unable to continue the propagation phase of lipid peroxidation [416]. Vitamin C is effective in scavenging several ROS/RNS as well as in the detoxification of peroxyl and hydroxyl radicals [405]. CoQ10 is involved in the neutralization of the damages induced by peroxyl radicals and also in the regeneration of vitamin E [407]. Uric acid is known to prevent protein nitrosylation, as well as lipid and protein peroxidation, and therefore it is considered as a protectant agent of the CNS [417]. Melatonin is a natural scavenger derived from tryptophan, which is involved in the neutralization of several ROS/RNS and thus reduces the generation of reactive aldehydes [415]. Finally, flavonoids and polyphenols are ubiquitous plant-derived molecules, which act as chelators and scavengers of ROS/RNS as well as of hydroxyl and peroxyl radicals [418,419].

\section{Conclusions}

Oxidative stress represents an underlying disturbance that is involved in many pathophysiological conditions. Increasing evidence suggests that tissues with a high oxygen consumption, such as brain and heart among others, are particularly sensitive to lipid peroxidation products and free radical accumulation, which are responsible for oxidative stress-induced damages with consequent cell death $[2,4-6,218]$.

Thus, acting on the cellular processes that suppress the generation of these reactive small molecules or altering the expression and/or activity of enzymes involved in their formation may be crucial for the treatment of a growing number of diseases linked with redox homeostasis deregulation.

In this scenario, there is rising acknowledgment about a cross-talk between the ECS and various redox-dependent processes. Indeed, it has been observed that the redox impairment induces the enhancement of AEA and 2-AG levels, as a consequence of phospholipid hydrolysis [420,421], and the upregulation of CB1 and CB2 expression [422,423], as well as the downregulation of FAAH [422].

A large number of reports point to the involvement of ECs and their lipid analogues in regulating ROS/RNS and reactive aldehydes generation through targeting CB1 and CB2 [8-10] and thereby exerting protective effects in cardiovascular as well as renal, hepatic, neuropsychiatric, and neurodegenerative diseases.

Moreover, it has been observed that, depending on the type of cell and/or injury, cannabinoid receptors show opposite effects in oxidative stress modulation, since $\mathrm{CB} 1$ activation results in a redox imbalance enhancement, while CB2 stimulation is responsible for lowering oxidative stress $[9,223]$ and may convey beneficial free radical scavenging effects.

Overall, the mechanisms by which CB2 receptors, following ECs-mediated activation, are involved in the reduction of oxidative injury seem to be primarily mediated by the reduction of NOX2 and NOX4, and the simultaneous induction of the antioxidant defense through the increase of the SOD scavenging enzymes [180,181].

Emerging evidence indicates that the neuroprotective, cardioprotective and renoprotective effects of ECs and NAEs are additionally mediated by CB1/CB2-independent mechanisms and involve the contribution of alternative intracellular targets such as PPAR- $\alpha$, TRPV1, GPR55, and GPR18 [169,348,349,370,371,395].

In particular, an interplay between PPAR- $\alpha$ and oxidative stress has been suggested from the observation that an imbalance in the redox state may modulate several signaling pathways, including PPAR- $\alpha$ signaling, via transcriptional regulation and post-translational modification. 
Among the PPAR- $\alpha$ ligands, PEA appeared to exert beneficial effects by simultaneously enhancing the antioxidant defense through the increase of SOD expression and inhibiting NOXs activity with a consequent reduction of the lipid peroxidation products such as MDA [138].

Although the huge amount of knowledge has been gained about the effects of the ECs on oxidative stress and lipid peroxidation in several pathological conditions, many ECS compounds fail during clinical trials due to inefficacy or unforeseeable safety concerns. For the treatment of the cardiovascular diseases, for instance, no cannabinoid-based drugs have been approved so far, except for those acting as PPARs agonists [348]. Among the limitations that play a role in restricting the translation of ECs studies into clinical trials, the different animal paradigms as well as the route of administration used (central vs peripheral) and the differences between species seem to be primarily involved.

Moreover, most of the studies have focused on the role of CB1, CB2, TRPV1, PPARs and less is known about other candidates such as GPR18, GPR55 and GPR119.

Despite promising goals have been achieved over the last years on ECS research, there is an urgent necessity to expand the knowledge on the ECs complex signalling in order to better identify an explanation of the serious side-effects observed in clinical studies. Lessons from clinical experience should encourage the scientific community to better clarify how to modulate the ECS thus leading to major breakthroughs in the treatment of many diseases.

Overall, the findings discussed in this review may further elucidate the complex interaction existing between ECS, oxidative stress, and lipid peroxidation, resulting in a better understanding of the multiple beneficial effects of this signaling system in several pathological conditions related to a redox status impairment.

Author Contributions: The project idea was developed by S.G., T.C. and A.M.G.; C.A.G., S.C., T.C., and A.R. wrote the first draft of the manuscript. C.A.G, S.C., A.R., J.B.K., M.d.C., T.C., S.G., D.D., R.V., and A.M.G. conducted the literature review and revised the manuscript. S.C., C.A.G., and D.D. created the figures.

Funding: This project was supported by the Italian Ministry for Education, University and Research (PRIN20153NBRS3_003 to S.G.).

Conflicts of Interest: The authors declare no conflict of interest.

\section{Abbreviations}

$\bullet \mathrm{NO}=$ nitric oxide; $\bullet \mathrm{OH}=$ hydroxyl radical; ${ }^{1} \mathrm{O}_{2}=$ oxygen singlet; 2 - $\mathrm{AG}=2$-arachidonoyl-glycerol; 2 -AGE = 2-arachidonoylglyceryl ether or noladin ether; 4-HHE = 4-hydroxy-hexanal; 4-HNE = 4-hydroxy-2-nonenal; 4-ONE = 4-oxo-nonenal; 6-OHDA = 6-hydroxydopamine; $\mathrm{AC}=$ adenylyl cyclase; $\mathrm{ACOX1}$ = acyl-CoA oxidase 1; ACR $=$ acrolein; $\mathrm{AEA}=\mathrm{N}$-arachidonoyl-ethanolamine or anandamide; $\mathrm{ApoE}^{-/}=$Apolipoprotein E-deficient mice; ARA-S = arachidonoyl-L-serine; AT1 = angiotensin II type 1 receptor; CAMKII $=\mathrm{Ca}^{2+} /$ calmodulin-dependent protein kinase II; cAMP = adenosine $3^{\prime}, 5^{\prime}$-cyclic monophosphate; CAT = catalase; $\mathrm{CB1}=$ cannabinoid receptor type 1 ; $\mathrm{CB} 2$ = cannabinoid receptor type 2 ; CD36 = cluster of differentiation 36 ; CGD = chronic granulomatous disorder; cGMP = guanosine $3^{\prime}, 5^{\prime}$-cyclic monophosphate; CNS = central nervous system; CoQ10 = coenzyme Q10; COX-2 = cyclooxygenase type 2; COXs = cyclooxygenases; CREB = cAMP response element binding protein; $\mathrm{CTA}=$ crotonaldehyde; $\mathrm{DAGL}=$ diacylglycerol lipase; $\mathrm{dG}=$ deoxyguanosine; $\mathrm{ECS}$ = endocannabinoid system; ECs = endocannabinoids; eNOS = endothelial nitric oxide synthase; ERK1/2 = extracellular signal-related kinases; FAAH = fatty acid amide hydrolase; GPCRs = G-protein-coupled receptors; GPR18 = G protein-coupled receptor 18; GPR55 = G protein-coupled receptor 55; GPR119 = G protein-coupled receptor 119; GPx = glutathione peroxidase; GR = glutathione reductase; GSH = glutathione; GSSG = oxidized glutathione; GT = glutathione transferase; GTPase = guanosine triphosphatase; $\mathrm{H}_{2} \mathrm{O}_{2}=$ hydrogen peroxide; $\mathrm{HClO}=$ hypochlorous acid; HEK = human embryonic kidney; I/R = ischemia/reperfusion; JNK = c-Jun $N$-terminal kinase; LOXs = lipooxygenases; LPI = L- $\alpha$-lysophosphatidylinositol; MAG = monoacylglycerols; MAGL = monoacylglycerol lipase; MAPKs = mitogen-activated protein kinases; MAPK $/$ ERK $1 / 2=$ mitogen-activated protein kinases/extracellular signal-regulated kinases; MDA = malondialdehyde; NADA $=N$-arachidonoyldopamine; NAEs $=N$-acylethanolamines; NAGLy $=N$-arachidonoylglycine; NAPE $=$ $\mathrm{N}$-acyl-phosphatidylethanolamine; NAPE-PLD = NAPE-phospholipase D; NF- $\mathrm{BB}=$ nuclear factor- $\mathrm{kB} ; \mathrm{NO}_{2}$ = nitric dioxide; $\mathrm{NO}_{2}{ }^{-}=$nitrite; $\mathrm{NO}_{3}{ }^{-}=$nitrate; $\mathrm{NOS}=$ nitric oxide synthase; $\mathrm{NOS1}=$ NOS type $1 ; \mathrm{NOX} 2=\mathrm{NOX}$ type 2; NOX3 = NOX type 3; NOXs = NADPH oxidase enzymes; Nrf2 = nuclear factor-erythroid 2-related factor 2; $\mathrm{O}_{2} \bullet-$ = superoxide anion; $\mathrm{O}_{3}=$ ozone; ODA = Cis-9,10-octadecanoamide or oleamide; $\mathrm{OEA}=$ oleoylethanolamide; OLDA = N-oleoyldopamine; $\mathrm{ONOO}^{-}=$peroxynitrite; oxLDL = oxidized low-density lipoproteins; PEA = palmitoylethanolamide; PGE2 = prostaglandin E2; PIP2 = phosphatidylinositol 4,5-bisphosphate; PIP3 = phosphatidylinositol 3,4,5-trisphosphate; PKA = protein kinase A; PKC = protein kinase C; PMP70 = peroxisomal 
membrane protein-70; PPARs = peroxisome proliferator-activated receptors; PPRES = peroxisome proliferator response elements; PUFAs = polyunsatured fatty acids; Rap $=$ Ras-related protein; Rap1GAP = Rap1 GTPase activating protein; RhoGEFs = RhoGTPase nucleotide exchange factors; ROS $/ \mathrm{RNS}=$ reactive oxygen and nitrogen species; RXR = retinoid $\mathrm{X}$ receptor; $\mathrm{SEA}=$ stearoylethanolamide; $\mathrm{SFK}$ s $=$ Src family kinases; $\mathrm{SGK} 1=$ serum glucocorticoid-induced protein kinase-1; $\mathrm{SOD}=$ superoxide dismutase; $\mathrm{TRP}=$ transient receptor potential; TRPV $=$ transient receptor potential vanilloid; $\mathrm{TRPV} 1=$ transient receptor potential vanilloid 1 ; $\operatorname{Tr} x=$ thioredoxin; $\operatorname{Tr} x \mathrm{R}=$ thioredoxin reductase.

\section{References}

1. Pomara, C.; Cassano, T.; D’Errico, S.; Bello, S.; Romano, A.D.; Riezzo, I.; Serviddio, G. Data available on the extent of cocaine use and dependence: Biochemistry, pharmacologic effects and global burden of disease of cocaine abusers. Curr. Med. Chem. 2012, 19, 5647-5657. [CrossRef] [PubMed]

2. Matthews, A.T.; Ross, M.K. Oxyradical Stress, Endocannabinoids, and Atherosclerosis. Toxics 2015, 3, 481-498. [CrossRef] [PubMed]

3. Sureshbabu, A.; Ryter, S.W.; Choi, M.E. Oxidative stress and autophagy: Crucial modulators of kidney injury. Redox Biol. 2015, 4, 208-214. [CrossRef] [PubMed]

4. Cassano, T.; Serviddio, G.; Gaetani, S.; Romano, A.; Dipasquale, P.; Cianci, S.; Bellanti, F.; Laconca, L.; Romano, A.D.; Padalino, I.; et al. Glutamatergic alterations and mitochondrial impairment in a murine model of Alzheimer disease. Neurobiol. Aging 2012, 33, 1121-e1. [CrossRef] [PubMed]

5. Cassano, T.; Pace, L.; Bedse, G.; Lavecchia, A.M.; De Marco, F.; Gaetani, S.; Serviddio, G. Glutamate and Mitochondria: Two Prominent Players in the Oxidative Stress-Induced Neurodegeneration. Curr. Alzheimer Res. 2016, 13, 185-197. [CrossRef] [PubMed]

6. Serviddio, G.; Romano, A.D.; Cassano, T.; Bellanti, F.; Altomare, E.; Vendemiale, G. Principles and therapeutic relevance for targeting mitochondria in aging and neurodegenerative diseases. Curr. Pharm. Des. 2011, 17, 2036-2055. [CrossRef] [PubMed]

7. Guéraud, F.; Atalay, M.; Bresgen, N.; Cipak, A.; Eckl, P.M.; Huc, L.; Jouanin, I.; Siems, W.; Uchida, K. Chemistry and biochemistry of lipid peroxidation products. Free Radic. Res. 2010, 44, 1098-1124. [CrossRef] [PubMed]

8. Mukhopadhyay, P.; Rajesh, M.; Bátkai, S.; Patel, V.; Kashiwaya, Y.; Liaudet, L.; Evgenov, O.V.; Mackie, K.; Haskó, G.; Pacher, P. CB1 cannabinoid receptors promote oxidative stress and cell death in murine models of doxorubicin-induced cardiomyopathy and in human cardiomyocytes. Cardiovasc. Res. 2010, 85, 773-784. [CrossRef] [PubMed]

9. Han, K.H.; Lim, S.; Ryu, J.; Lee, C.W.; Kim, Y.; Kang, J.H.; Kang, S.S.; Ahn, Y.K.; Park, C.S.; Kim, J.J. CB1 and CB2 cannabinoid receptors differentially regulate the production of reactive oxygen species by macrophages. Cardiovasc. Res. 2009, 84, 378-386. [CrossRef] [PubMed]

10. Hao, X.; Chen, J.; Luo, Z.; He, H.; Yu, H.; Ma, L.; Ma, S.; Zhu, T.; Liu, D.; Zhu, Z. TRPV1 activation prevents high-salt diet-induced nocturnal hypertension in mice. Pflügers Arch. Eur. J. Physiol. 2011, 461, 345-353. [CrossRef] [PubMed]

11. Sies, H. Oxidative stress: A concept in redox biology and medicine. Redox Biol. 2015, 4, 180-183. [CrossRef] [PubMed]

12. Di Meo, S.; Reed, T.T.; Venditti, P.; Victor, V.M. Role of ROS and RNS Sources in Physiological and Pathological Conditions. Oxid. Med. Cell. Longev. 2016, 2016, 1245049. [CrossRef] [PubMed]

13. Weidinger, A.; Kozlov, A.V. Biological Activities of Reactive Oxygen and Nitrogen Species: Oxidative Stress versus Signal Transduction. Biomolecules 2015, 5, 472-484. [CrossRef] [PubMed]

14. Liu, Y.; Fiskum, G.; Schubert, D. Generation of reactive oxygen species by the mitochondrial electron transport chain. J. Neurochem. 2002, 80, 780-787. [CrossRef] [PubMed]

15. Aguirre, J.; Lambeth, J.D. Nox enzymes from fungus to fly to fish and what they tell us about Nox function in mammals. Free Radic. Biol. Med. 2010, 49, 1342-1353. [CrossRef] [PubMed]

16. Panday, A.; Sahoo, M.K.; Osorio, D.; Batra, S. NADPH oxidases: An overview from structure to innate immunity-associated pathologies. Cell. Mol. Immunol. 2015, 12, 5-23. [CrossRef] [PubMed]

17. Sevier, C.S.; Kaiser, C.A. Ero1 and redox homeostasis in the endoplasmic reticulum. Biochim. Biophys. Acta 2008, 1783, 549-556. [CrossRef] [PubMed] 
18. Wang, W.; Wang, S.; Yan, L.; Madara, P.; Del Pilar Cintron, A.; Wesley, R.A.; Danner, R.L. Superoxide production and reactive oxygen species signaling by endothelial nitric-oxide synthase. J. Biol. Chem. 2000, 275, 16899-16903. [CrossRef] [PubMed]

19. Hrycay, E.G.; Bandiera, S.M. Involvement of Cytochrome P450 in Reactive Oxygen Species Formation and Cancer. Adv. Pharmacol. 2015, 74, 35-84. [CrossRef] [PubMed]

20. Nathan, C.; Cunningham-Bussel, A. Beyond oxidative stress: An immunologist's guide to reactive oxygen species. Nat. Rev. Immunol. 2013, 13, 349-361. [CrossRef] [PubMed]

21. Vergeade, A.; Mulder, P.; Vendeville, C.; Ventura-Clapier, R.; Thuillez, C.; Monteil, C. Xanthine oxidase contributes to mitochondrial ROS generation in an experimental model of cocaine-induced diastolic dysfunction. J. Cardiovasc. Pharmacol. 2012, 60, 538-543. [CrossRef] [PubMed]

22. McGrath, A.P.; Hilmer, K.M.; Collyer, C.A.; Shepard, E.M.; Elmore, B.O.; Brown, D.E.; Dooley, D.M.; Guss, J.M. Structure and inhibition of human diamine oxidase. Biochemistry 2009, 48, 9810-9822. [CrossRef] [PubMed]

23. Marnett, L.J. Prostaglandin synthase-mediated metabolism of carcinogens and a potential role for peroxyl radicals as reactive intermediates. Environ. Health Perspect. 1990, 88, 5-12. [CrossRef] [PubMed]

24. Schröder, P.; Krutmann, J. Environmental Oxidative Stress-Environmental Sources of ROS. In Reactions, Processes; Grune, T., Ed.; Springer: Berlin/Heidelberg, Germany, 2005; Volume 2, ISBN 3540235876.

25. Dupré-Crochet, S.; Erard, M.; Nüße, O. ROS production in phagocytes: Why, when, and where? J. Leukoc. Biol. 2013, 94, 657-670. [CrossRef] [PubMed]

26. Görlach, A.; Bertram, K.; Hudecova, S.; Krizanova, O. Calcium and ROS: A mutual interplay. Redox Biol. 2015, 6, 260-271. [CrossRef] [PubMed]

27. Winkelstein, J.A.; Marino, M.C.; Johnston, R.B., Jr.; Boyle, J.; Curnutte, J.; Gallin, J.I.; Malech, H.L.; Holland, S.M.; Ochs, H.; Quie, P.; et al. Chronic granulomatous disease. Report on a national registry of 368 patients. Medicine 2000, 79, 155-169. [CrossRef]

28. Quie, P.G.; White, J.G.; Holmes, B.; Good, R.A. In vitro bactericidal capacity of human polymorphonuclear leukocytes: Diminished activity in chronic granulomatous disease of childhood. J. Clin. Investig. 1967, 46, 668-679. [CrossRef] [PubMed]

29. Holmes, B.; Quie, P.G.; Windhorst, D.B.; Good, R.A. Fatal granulomatous disease of childhood. An inborn abnormality of phagocytic function. Lancet 1966, 1, 1225-1228. [CrossRef]

30. Bylund, J.; Goldblatt, D.; Speert, D.P. Chronic granulomatous disease: From genetic defect to clinical presentation. Adv. Exp. Med. Biol. 2005, 568, 67-87. [CrossRef] [PubMed]

31. Quinn, M.T.; Ammons, M.C.; Deleo, F.R. The expanding role of NADPH oxidases in health and disease: No longer just agents of death and destruction. Clin. Sci. 2006, 111, 1-20. [CrossRef] [PubMed]

32. Cifuentes, M.E.; Pagano, P.J. Targeting reactive oxygen species in hypertension. Curr. Opin. Nephrol. Hypertens. 2006, 15, 179-186. [CrossRef] [PubMed]

33. Moncada, S.; Higgs, E.A. The discovery of nitric oxide and its role in vascular biology. Br. J. Pharmacol. 2006, 147 (Suppl. 1), S193-S201. [CrossRef] [PubMed]

34. Drummond, G.R.; Sobey, C.G. Endothelial NADPH oxidases: Which NOX to target in vascular disease? Trends Endocrinol. Metab. 2014, 25, 452-463. [CrossRef] [PubMed]

35. Wilcox, C.S. Redox regulation of the afferent arteriole and tubuloglomerular feedback. Acta Physiol. Scand. 2003, 179, 217-223. [CrossRef] [PubMed]

36. Wilcox, C.S. Oxidative stress and nitric oxide deficiency in the kidney: A critical link to hypertension? Am. J. Physiol. Regul. Integr. Comp. Physiol. 2005, 289, R913-R935. [CrossRef] [PubMed]

37. Zou, A.P.; Cowley, A.W., Jr. Reactive oxygen species and molecular regulation of renal oxygenation. Acta Physiol. Scand. 2003, 179, 233-241. [CrossRef] [PubMed]

38. Juncos, R.; Hong, N.J.; Garvin, J.L. Differential effects of superoxide on luminal and basolateral $\mathrm{Na}^{+} / \mathrm{H}^{+}$ exchange in the thick ascending limb. Am. J. Physiol. Regul. Integr. Comp. Physiol. 2006, 290, R79-R83. [CrossRef] [PubMed]

39. Hoidal, J.R.; Brar, S.S.; Sturrock, A.B.; Sanders, K.A.; Dinger, B.; Fidone, S.; Kennedy, T.P. The role of endogenous NADPH oxidases in airway and pulmonary vascular smooth muscle function. Antioxid. Redox Signal. 2003, 5, 751-758. [CrossRef] [PubMed]

40. Brar, S.S.; Kennedy, T.P.; Sturrock, A.B.; Huecksteadt, T.P.; Quinn, M.T.; Murphy, T.M.; Chitano, P.; Hoidal, J.R. NADPH oxidase promotes NF-kappaB activation and proliferation in human airway smooth muscle. Am. J. Physiol. Lung Cell. Mol. Physiol. 2002, 282, L782L795. [CrossRef] [PubMed] 
41. Piao, Y.J.; Seo, Y.H.; Hong, F.; Kim, J.H.; Kim, Y.J.; Kang, M.H.; Kim, B.S.; Jo, S.A.; Jo, I.; Jue, D.M.; et al. Nox 2 stimulates muscle differentiation via NF-kappaB/iNOS pathway. Free Radic. Biol. Med. 2005, 38, 989-1001. [CrossRef] [PubMed]

42. Kojim, S.; Ikeda, M.; Shibukawa, A.; Kamikawa, Y. Modification of 5-hydroxytryptophan-evoked 5-hydroxytryptamine formation of guinea pig colonic mucosa by reactive oxygen species. Jpn. J. Pharmacol. 2002, 88, 114-118. [CrossRef] [PubMed]

43. Wang, G.; Anrather, J.; Huang, J.; Speth, R.C.; Pickel, V.M.; Iadecola, C. NADPH oxidase contributes to angiotensin II signaling in the nucleus tractus solitarius. J. Neurosci. 2004, 24, 5516-5524. [CrossRef] [PubMed]

44. Erdös, B.; Broxson, C.S.; King, M.A.; Scarpace, P.J.; Tümer, N. Acute pressor effect of central angiotensin II is mediated by $\mathrm{NAD}(\mathrm{P}) \mathrm{H}$-oxidase-dependent production of superoxide in the hypothalamic cardiovascular regulatory nuclei. J. Hypertens. 2006, 24, 109-116. [CrossRef] [PubMed]

45. Mander, P.K.; Jekabsone, A.; Brown, G.C. Microglia proliferation is regulated by hydrogen peroxide from NADPH oxidase. J. Immunol. 2006, 176, 1046-1052. [CrossRef] [PubMed]

46. Fritz, K.S.; Petersen, D.R. An overview of the chemistry and biology of reactive aldehydes. Free Radic. Biol. Med. 2013, 59, 85-91. [CrossRef] [PubMed]

47. Yin, H.; Xu, L.; Porter, N.A. Free radical lipid peroxidation: Mechanisms and analysis. Chem. Rev. 2011, 111, 5944-5972. [CrossRef] [PubMed]

48. Niki, E.; Yoshida, Y.; Saito, Y.; Noguchi, N. Lipid peroxidation: Mechanisms, inhibition, and biological effects. Biochem. Biophys. Res. Commun. 2005, 338, 668-676. [CrossRef] [PubMed]

49. Porter, N.A.; Caldwell, S.E.; Mills, K.A. Mechanisms of free radical oxidation of unsaturated lipids. Lipids 1995, 30, 277-290. [CrossRef] [PubMed]

50. Forman, H.J.; Fukuto, J.M.; Miller, T.; Zhang, H.; Rinna, A.; Levy, S. The chemistry of cell signaling by reactive oxygen and nitrogen species and 4-hydroxynonenal. Arch. Biochem. Biophys. 2008, 477, 183-195. [CrossRef] [PubMed]

51. Poli, G.; Schaur, R.J.; Siems, W.G.; Leonarduzzi, G. 4-hydroxynonenal: A membrane lipid oxidation product of medicinal interest. Med. Res. Rev. 2008, 28, 569-631. [CrossRef] [PubMed]

52. Noguchi, N. Role of oxidative stress in adaptive responses in special reference to atherogenesis. J. Clin. Biochem. Nutr. 2008, 43, 131-138. [CrossRef] [PubMed]

53. Zmijewski, J.W.; Landar, A.; Watanabe, N.; Dickinson, D.A.; Noguchi, N.; Darley-Usmar, V.M. Cell signalling by oxidized lipids and the role of reactive oxygen species in the endothelium. Biochem. Soc. Trans. 2005, 33, 1385-1389. [CrossRef] [PubMed]

54. Romano, A.; Serviddio, G.; Calcagnini, S.; Villani, R.; Giudetti, A.M.; Cassano, T.; Gaetani, S. Linking lipid peroxidation and neuropsychiatric disorders: Focus on 4-hydroxy-2-nonenal. Free Radic. Biol. Med. 2017, 111, 281-293. [CrossRef] [PubMed]

55. Negre-Salvayre, A.; Coatrieux, C.; Ingueneau, C.; Salvayre, R. Advanced lipid peroxidation end products in oxidative damage to proteins. Potential role in diseases and therapeutic prospects for the inhibitors. Br. J. Pharmacol. 2008, 153, 6-20. [CrossRef] [PubMed]

56. Winczura, A.; Zdżalik, D.; Tudek, B. Damage of DNA and proteins by major lipid peroxidation products in genome stability. Free Radic. Res. 2012, 46, 442-459. [CrossRef] [PubMed]

57. Winter, C.K.; Segall, H.J.; Haddon, W.F. Formation of cyclic adducts of deoxyguanosine with the aldehydes trans-4-hydroxy-2-hexenal and trans-4-hydroxy-2-nonenal in vitro. Cancer Res. 1986, 46, 5682-5686. [PubMed]

58. Chung, F.L.; Young, R.; Hecht, S.S. Formation of cyclic $1, N^{2}$-propanodeoxyguanosine adducts in DNA upon reaction with acrolein or crotonaldehyde. Cancer Res. 1984, 44, 990-995. [PubMed]

59. Cohn, J.A.; Tsai, L.; Friguet, B.; Szweda, L.I. Chemical characterization of a protein-4-hydroxy-2-nonenal cross-link: Immunochemical detection in mitochondria exposed to oxidative stress. Arch. Biochem. Biophys. 1996, 328, 158-164. [CrossRef] [PubMed]

60. Seto, H.; Okuda, T.; Takesue, T.; Ikemura, T. Reaction of malonaldehyde with nucleic acid. I. Formation of fluorescent pyrimido[1,2-a]purin-10-one nucleosides. Bull. Chem. Soc. Jpn. 1983, 56, 1799-1802. [CrossRef]

61. Esterbauer, H. Cytotoxicity and genotoxicity of lipid-oxidation products. Am. J. Clin. Nutr. 1993, 57, 779S-785S. [CrossRef] [PubMed] 
62. Schaur, R.J. Basic aspects of the biochemical reactivity of 4-hydroxynonenal. Mol. Asp. Med. 2003, 24, 149-159. [CrossRef]

63. Zarkovic, N.; Cipak, A.; Jaganjac, M.; Borovic, S.; Zarkovic, K. Pathophysiological relevance of aldehydic protein modifications. J. Proteom. 2013, 92, 239-247. [CrossRef] [PubMed]

64. Rindgen, D.; Nakajima, M.; Wehrli, S.; Xu, K.; Blair, I.A. Covalent modifications to 2'-deoxyguanosine by 4-oxo-2-nonenal, a novel product of lipid peroxidation. Chem. Res. Toxicol. 1999, 12, 1195-1204. [CrossRef] [PubMed]

65. Lee, S.H.; Rindgen, D.; Bible, R.H., Jr.; Hajdu, E.; Blair, I.A. Characterization of 2'-deoxyadenosine adducts derived from 4-oxo-2-nonenal, a novel product of lipid peroxidation. Chem. Res. Toxicol. 2000, 13, 565-574. [CrossRef] [PubMed]

66. Pollack, M.; Oe, T.; Lee, S.H.; Silva Elipe, M.V.; Arison, B.H.; Blair, I.A. Characterization of 2'-deoxycytidine adducts derived from 4-oxo-2-nonenal, a novel lipid peroxidation product. Chem. Res. Toxicol. 2003, 16, 893-900. [CrossRef] [PubMed]

67. Williams, M.V.; Lee, S.H.; Pollack, M.; Blair, I.A. Endogenous lipid hydroperoxide-mediated DNA-adduct formation in min mice. J. Biol. Chem. 2006, 281, 10127-10133. [CrossRef] [PubMed]

68. Del Rio, D.; Stewart, A.J.; Pellegrini, N. A review of recent studies on malondialdehyde as toxic molecule and biological marker of oxidative stress. Nutr. Metab. Cardiovasc. Dis. 2005, 15, 316-328. [CrossRef] [PubMed]

69. Zhao, J.; Chen, J.; Zhu, H.; Xiong, Y.L. Mass spectrometric evidence of malonaldehyde and 4-hydroxynonenal adductions to radical-scavenging soy peptides. J. Agric. Food Chem. 2012, 60, 9727-9736. [CrossRef] [PubMed]

70. Mukai, F.H.; Goldstein, B.D. Mutagenicity of malonaldehyde, a decomposition product of peroxidized polyunsaturated fatty acids. Science 1976, 191, 868-869. [CrossRef] [PubMed]

71. Basu, A.K.; Marnett, L.J. Unequivocal demonstration that malondialdehyde is a mutagen. Carcinogenesis 1983, 4, 331-333. [CrossRef] [PubMed]

72. Marnett, L.J.; Hurd, H.K.; Hollstein, M.C.; Levin, D.E.; Esterbauer, H.; Ames, B.N. Naturally occurring carbonyl compounds are mutagens in Salmonella tester strain TA104. Mutat. Res. 1985, 148, 25-34. [CrossRef]

73. Vasanthi, P.; Nalini, G.; Rajasekhar, G. Status of oxidative stress in rheumatoid arthritis. Int. J. Rheum. Dis. 2009, 12, 29-33. [CrossRef] [PubMed]

74. Mishra, R.; Singh, A.; Chandra, V.; Negi, M.P.; Tripathy, B.C.; Prakash, J.; Gupta, V. A comparative analysis of serological parameters and oxidative stress in osteoarthritis and rheumatoid arthritis. Rheumatol. Int. 2012, 32, 2377-2382. [CrossRef] [PubMed]

75. Mateen, S.; Moin, S.; Khan, A.Q.; Zafar, A.; Fatima, N. Increased Reactive Oxygen Species Formation and Oxidative Stress in Rheumatoid Arthritis. PLOS ONE 2016, 11, e0152925. [CrossRef] [PubMed]

76. Shah, D.; Wanchu, A.; Bhatnagar, A. Interaction between oxidative stress and chemokines: Possible pathogenic role in systemic lupus erythematosus and rheumatoid arthritis. Immunobiology 2011, 216, 1010-1017. [CrossRef] [PubMed]

77. Liao, C.C.; Chang, Y.S.; Cheng, C.W.; Chi, W.M.; Tsai, K.L.; Chen, W.J.; Kung, T.S.; Tai, C.C.; Lin, Y.F.; Lin, H.T.; et al. Isotypes of autoantibodies against differentially expressed novel malondialdehyde-modified peptide adducts in serum of Taiwanese women with rheumatoid arthritis. J. Proteom. 2018, 170, 141-150. [CrossRef] [PubMed]

78. Cvetkovic, J.T.; Wållberg-Jonsson, S.; Ahmed, E.; Rantapää-Dahlqvist, S.; Lefvert, A.K. Increased levels of autoantibodies against copper-oxidized low density lipoprotein, malondialdehyde-modified low density lipoprotein and cardiolipin in patients with rheumatoid arthritis. Rheumatology 2002, 41, 988-995. [CrossRef] [PubMed]

79. Wållberg-Jonsson, S.; Cvetkovic, J.T.; Sundqvist, K.G.; Lefvert, A.K.; Rantapää-Dahlqvist, S. Activation of the immune system and inflammatory activity in relation to markers of atherothrombotic disease and atherosclerosis in rheumatoid arthritis. J. Rheumatol. 2002, 29, 875-882. [PubMed]

80. Chung, F.L.; Chen, H.J.; Nath, R.G. Lipid peroxidation as a potential endogenous source for the formation of exocyclic DNA adducts. Carcinogenesis 1996, 17, 2105-2111. [CrossRef] [PubMed]

81. Chung, F.L.; Nath, R.G.; Nagao, M.; Nishikawa, A.; Zhou, G.D.; Randerath, K. Endogenous formation and significance of $1, N^{2}$-propanodeoxyguanosine adducts. Mutat. Res. 1999, 424, 71-81. [CrossRef]

82. Wang, M.Y.; Chung, F.L.; Hecht, S.S. Identification of crotonaldehyde as a hepatic microsomal metabolite formed by alpha-hydroxylation of the carcinogen $N$-nitrosopyrrolidine. Chem. Res. Toxicol. 1988, 1, $28-31$. [CrossRef] [PubMed] 
83. Wang, M.; McIntee, E.J.; Cheng, G.; Shi, Y.; Villalta, P.W.; Hecht, S.S. Identification of paraldol-deoxyguanosine adducts in DNA reacted with crotonaldehyde. Chem. Res. Toxicol. 2000, 13, 1065-1074. [CrossRef] [PubMed]

84. International Agency for Research on Cancer. IARC Monographs on the Evaluation of Carcinogenic Risks to Humans. In Dry Cleaning, Some Chlorinated Solvents and Other Industrial Chemicals; International Agency for Research on Cancer: Lyon, France, 1995; Volume 63, pp. 373-391.

85. Chung, F.L.; Tanaka, T.; Hecht, S.S. Induction of liver tumors in F344 rats by crotonaldehyde. Cancer Res. 1986, 46, 1285-1289. [PubMed]

86. Ichihashi, K.; Osawa, T.; Toyokuni, S.; Uchida, K. Endogenous formation of protein adducts with carcinogenic aldehydes: Implications for oxidative stress. J. Biol. Chem. 2001, 276, 23903-23913. [CrossRef] [PubMed]

87. Furuhata, A.; Nakamura, M.; Osawa, T.; Uchida, K. Thiolation of protein-bound carcinogenic aldehyde. An electrophilic acrolein-lysine adduct that covalently binds to thiols. J. Biol. Chem. 2002, 277, 27919-27926. [CrossRef] [PubMed]

88. Uchida, K.; Kanematsu, M.; Morimitsu, Y.; Osawa, T.; Noguchi, N.; Niki, E. Acrolein is a product of lipid peroxidation reaction. Formation of free acrolein and its conjugate with lysine residues in oxidized low density lipoproteins. J. Biol. Chem. 1998, 273, 16058-16066. [CrossRef] [PubMed]

89. Esterbauer, H.; Schaur, R.J.; Zollner, H. Chemistry and biochemistry of 4-hydroxynonenal, malonaldehyde and related aldehydes. Free Radic. Biol. Med. 1991, 11, 81-128. [CrossRef]

90. Cohen, G.; Riahi, Y.; Sunda, V.; Deplano, S.; Chatgilialoglu, C.; Ferreri, C.; Kaiser, N.; Sasson, S. Signaling properties of 4-hydroxyalkenals formed by lipid peroxidation in diabetes. Free Radic. Biol. Med. 2013, 65, 978-987. [CrossRef] [PubMed]

91. Higdon, A.; Diers, A.R.; Oh, J.Y.; Landar, A.; Darley-Usmar, V.M. Cell signalling by reactive lipid species: New concepts and molecular mechanisms. Biochem. J. 2012, 442, 453-464. [CrossRef] [PubMed]

92. Riahi, Y.; Cohen, G.; Shamni, O.; Sasson, S. Signaling and cytotoxic functions of 4-hydroxyalkenals. Am. J. Physiol. Endocrinol. Metab. 2010, 299, E879-E886. [CrossRef] [PubMed]

93. Schaur, R.J.; Siems, W.; Bresgen, N.; Eckl, P.M. 4-Hydroxy-nonenal-A Bioactive Lipid Peroxidation Product. Biomolecules 2015, 5, 2247-2337. [CrossRef] [PubMed]

94. Calabrese, E.J.; Bachmann, K.A.; Bailer, A.J.; Bolger, P.M.; Borak, J.; Cai, L.; Cedergreen, N.; Cherian, M.G.; Chiueh, C.C.; Clarkson, T.W.; et al. Biological stress response terminology: Integrating the concepts of adaptive response and preconditioning stress within a hormetic dose-response framework. Toxicol. Appl. Pharmacol. 2007, 222, 122-128. [CrossRef] [PubMed]

95. Pizzimenti, S.; Barrera, G.; Dianzani, M.U.; Brüsselbach, S. Inhibition of D1, D2, and A-cyclin expression in HL-60 cells by the lipid peroxydation product 4-hydroxynonenal. Free Radic. Biol. Med. 1999, 26, 1578-1586. [CrossRef]

96. Huang, Y.; Li, W.; Kong, A.N. Anti-oxidative stress regulator NF-E2-related factor 2 mediates the adaptive induction of antioxidant and detoxifying enzymes by lipid peroxidation metabolite 4-hydroxynonenal. Cell Biosci. 2012, 2, 40. [CrossRef] [PubMed]

97. Zhang, Y.; Sano, M.; Shinmura, K.; Tamaki, K.; Katsumata, Y.; Matsuhashi, T.; Morizane, S.; Ito, H.; Hishiki, T.; Endo, J.; et al. 4-hydroxy-2-nonenal protects against cardiac ischemia-reperfusion injury via the Nrf2-dependent pathway. J. Mol. Cell. Cardiol. 2010, 49, 576-586. [CrossRef] [PubMed]

98. Siow, R.C.; Ishii, T.; Mann, G.E. Modulation of antioxidant gene expression by 4-hydroxynonenal: Atheroprotective role of the Nrf2/ARE transcription pathway. Redox Rep. 2007, 12, 11-15. [CrossRef] [PubMed]

99. Tanito, M.; Agbaga, M.P.; Anderson, R.E. Upregulation of thioredoxin system via Nrf2-antioxidant responsive element pathway in adaptive-retinal neuroprotection in vivo and in vitro. Free Radic. Biol. Med. 2007, 42, 1838-1850. [CrossRef] [PubMed]

100. Ishii, T.; Itoh, K.; Ruiz, E.; Leake, D.S.; Unoki, H.; Yamamoto, M.; Mann, G.E. Role of Nrf2 in the regulation of CD36 and stress protein expression in murine macrophages: Activation by oxidatively modified LDL and 4-hydroxynonenal. Circ. Res. 2004, 94, 609-616. [CrossRef] [PubMed]

101. De Petrocellis, L.; Cascio, M.G.; Di Marzo, V. The endocannabinoid system: A general view and latest additions. Br. J. Pharmacol. 2004, 141, 765-774. [CrossRef] [PubMed]

102. Mechoulam, R.; Fride, E.; Di Marzo, V. Endocannabinoids. Eur. J. Pharmacol. 1998, 359, 1-18. [CrossRef] 
103. Devane, W.A.; Hanus, L.; Breuer, A.; Pertwee, R.G.; Stevenson, L.A.; Griffin, G.; Gibson, D.; Mandelbaum, A.; Etinger, A.; Mechoulam, R. Isolation and structure of a brain constituent that binds to the cannabinoid receptor. Science 1992, 258, 1946-1949. [CrossRef] [PubMed]

104. Sierra, S.; Luquin, N.; Navarro-Otano, J. The endocannabinoid system in cardiovascular function: Novel insights and clinical implications. Clin. Auton Res. 2018, 28, 35-52. [CrossRef] [PubMed]

105. Fonseca, B.M.; Costa, M.A.; Almada, M.; Correia-da-Silva, G.; Teixeira, N.A. Endogenous cannabinoids revisited: A biochemistry perspective. Prostaglandins Other Lipid Mediat. 2013, 102-103, 13-30. [CrossRef] [PubMed]

106. Sugiura, T.; Kondo, S.; Sukagawa, A.; Nakane, S.; Shinoda, A.; Itoh, K.; Yamashita, A.; Waku, K. 2-Arachidonoylglycerol: A possible endogenous cannabinoid receptor ligand in brain. Biochem. Biophys. Res. Commun. 1995, 215, 89-97. [CrossRef] [PubMed]

107. Stella, N.; Schweitzer, P.; Piomelli, D. A second endogenous cannabinoid that modulates long-term potentiation. Nature 1997, 388, 773-778. [CrossRef] [PubMed]

108. Fonseca, B.M.; Correia-da-Silva, G.; Taylor, A.H.; Lam, P.M.; Marczylo, T.H.; Bell, S.C.; Konje, J.C.; Teixeira, N.A. The endocannabinoid 2-arachidonoylglycerol (2-AG) and metabolizing enzymes during rat fetoplacental development: A role in uterine remodelling. Int. J. Biochem. Cell Biol. 2010, 42, 1884-1892. [CrossRef] [PubMed]

109. Fonseca, B.M.; Correia-da-Silva, G.; Taylor, A.H.; Lam, P.M.; Marczylo, T.H.; Konje, J.C.; Bell, S.C.; Teixeira, N.A. N-acylethanolamine levels and expression of their metabolizing enzymes during pregnancy. Endocrinology 2010, 151, 3965-3974. [CrossRef] [PubMed]

110. Di Marzo, V. The endocannabinoid system: Its general strategy of action, tools for its pharmacological manipulation and potential therapeutic exploitation. Pharmacol. Res. 2009, 60, 77-84. [CrossRef] [PubMed]

111. Gonsiorek, W.; Lunn, C.; Fan, X.; Narula, S.; Lundell, D.; Hipkin, R.W. Endocannabinoid 2-arachidonyl glycerol is a full agonist through human type 2 cannabinoid receptor: Antagonism by anandamide. Mol. Pharmacol. 2000, 57, 1045-1050. [PubMed]

112. Pertwee, R.G. The pharmacology of cannabinoid receptors and their ligands: An overview. Int. J. Obes. 2006, 30 (Suppl. 1), S13-S18. [CrossRef] [PubMed]

113. Matsuda, L.A.; Lolait, S.J.; Brownstein, M.J.; Young, A.C.; Bonner, T.I. Structure of a cannabinoid receptor and functional expression of the cloned cDNA. Nature 1990, 346, 561-564. [CrossRef] [PubMed]

114. Freund, T.F.; Katona, I.; Piomelli, D. Role of endogenous cannabinoids in synaptic signaling. Physiol. Rev. 2003, 83, 1017-1066. [CrossRef] [PubMed]

115. Pacher, P.; Steffens, S. The emerging role of the endocannabinoid system in cardiovascular disease. Semin. Immunopathol. 2009, 31, 63-77. [CrossRef] [PubMed]

116. Tam, J.; Hinden, L.; Drori, A.; Udi, S.; Azar, S.; Baraghithy, S. The therapeutic potential of targeting the peripheral endocannabinoid $/ \mathrm{CB}_{1}$ receptor system. Eur. J. Intern. Med. 2018, 49, 23-29. [CrossRef] [PubMed]

117. Hu, S.S.; Mackie, K. Distribution of the Endocannabinoid System in the Central Nervous System. Handb. Exp. Pharmacol. 2015, 231, 59-93. [CrossRef] [PubMed]

118. Bénard, G.; Massa, F.; Puente, N.; Lourenço, J.; Bellocchio, L.; Soria-Gómez, E.; Matias, I.; Delamarre, A.; Metna-Laurent, M.; Cannich, A.; et al. Mitochondrial $\mathrm{CB}_{1}$ receptors regulate neuronal energy metabolism. Nat. Neurosci. 2012, 15, 558-564. [CrossRef] [PubMed]

119. Pacher, P.; Kunos, G. Modulating the endocannabinoid system in human health and disease-Successes and failures. FEBS J. 2013, 280, 1918-1943. [CrossRef] [PubMed]

120. Pertwee, R.G. Cannabinoid receptor ligands: Clinical and neuropharmacological considerations, relevant to future drug discovery and development. Expert Opin. Investig. Drugs 2000, 9, 1553-1571. [CrossRef] [PubMed]

121. Jordan, J.D.; Carey, K.D.; Stork, P.J.; Iyengar, R. Modulation of rap activity by direct interaction of Galpha(o) with Rap1 GTPase-activating protein. J. Biol. Chem. 1999, 274, 21507-21510. [CrossRef] [PubMed]

122. Glass, M.; Felder, C.C. Concurrent stimulation of cannabinoid CB1 and dopamine D2 receptors augments cAMP accumulation in striatal neurons: Evidence for a $G_{s}$ linkage to the CB1 receptor. J. Neurosci. 1997, 17, 5327-5333. [CrossRef] [PubMed] 
123. Maneuf, Y.P.; Brotchie, J.M. Paradoxical action of the cannabinoid WIN 55, 212-212 in stimulated and basal cyclic AMP accumulation in rat globus pallidus slices. Br. J. Pharmacol. 1997, 120, 1397-1398. [CrossRef] [PubMed]

124. Howlett, A.C. Cannabinoid receptor signaling. Handb. Exp. Pharmacol. 2005, 168, 53-79. [CrossRef]

125. Turu, G.; Hunyady, L. Signal transduction of the CB1 cannabinoid receptor. J. Mol. Endocrinol. 2010, 44, 75-85. [CrossRef] [PubMed]

126. Pacher, P.; Batkai, S.; Kunos, G. The endocannabinoid system as an emerging target of pharmacotherapy. Pharmacol. Rev. 2006, 58, 389-462. [CrossRef] [PubMed]

127. Zygmunt, P.M.; Petersson, J.; Andersson, D.A.; Chuang, H.; Sørgård, M.; Di Marzo, V.; Julius, D.; Högestätt, E.D. Vanilloid receptors on sensory nerves mediate the vasodilator action of anandamide. Nature 1999, 400, 452-457. [CrossRef] [PubMed]

128. Starowicz, K.; Nigam, S.; Di Marzo, V. Biochemistry and pharmacology of endovanilloids. Pharmacol. Ther. 2007, 114, 13-33. [CrossRef] [PubMed]

129. Di Marzo, V.; De Petrocellis, L. Endocannabinoids as regulators of transient receptor potential (TRP) channels: A further opportunity to develop new endocannabinoid-based therapeutic drugs. Curr. Med. Chem. 2010, 17, 1430-1449. [CrossRef] [PubMed]

130. O'Sullivan, S.E. Cannabinoids go nuclear: Evidence for activation of peroxisome proliferator-activated receptors. Br. J. Pharmacol. 2007, 152, 576-582. [CrossRef] [PubMed]

131. Lu, H.C.; Mackie, K. An introduction to the endogenous cannabinoid system. Biol. Psychiatry 2016, 79, 516-525. [CrossRef] [PubMed]

132. Haugh, O.; Penman, J.; Irving, A.J.; Campbell, V.A. The emerging role of the cannabinoid receptor family in peripheral and neuro-immune interactions. Curr. Drug Targets 2016, 17, 1834-1840. [CrossRef] [PubMed]

133. Yang, D.; Luo, Z.; Ma, S.; Wong, W.T.; Ma, L.; Zhong, J.; He, H.; Zhao, Z.; Cao, T.; Yan, Z.; et al. Activation of TRPV1 by dietary capsaicin improves endothelium-dependent vasorelaxation and prevents hypertension. Cell Metab. 2010, 12, 130-141. [CrossRef] [PubMed]

134. Poblete, I.M.; Orliac, M.L.; Briones, R.; Adler-Graschinsky, E.; Huidobro-Toro, J.P. Anandamide elicits an acute release of nitric oxide through endothelial TRPV1 receptor activation in the rat arterial mesenteric bed. J. Physiol. 2005, 568, 539-551. [CrossRef] [PubMed]

135. Randhawa, P.K.; Jaggi, A.S. TRPV1 channels in cardiovascular system: A double edged sword? Int. J. Cardiol. 2017, 228, 103-113. [CrossRef] [PubMed]

136. Di Marzo, V.; Bisogno, T.; De Petrocellis, L. Anandamide: Some like it hot. Trends Pharmacol. Sci. 2001, 22, 346-349. [CrossRef]

137. Starowicz, K.; Makuch, W.; Osikowicz, M.; Piscitelli, F.; Petrosino, S.; Di Marzo, V.; Przewlocka, B. Spinal anandamide produces analgesia in neuropathic rats: Possible $\mathrm{CB}_{1}$ - and TRPV1-mediated mechanisms. Neuropharmacology 2012, 62, 1746-1755. [CrossRef] [PubMed]

138. Mattace Raso, G.; Simeoli, R.; Russo, R.; Santoro, A.; Pirozzi, C.; d'Emmanuele di Villa Bianca, R.; Mitidieri, E.; Paciello, O.; Pagano, T.B.; Orefice, N.S.; et al. N-Palmitoylethanolamide protects the kidney from hypertensive injury in spontaneously hypertensive rats via inhibition of oxidative stress. Pharmacol. Res. 2013, 76, 67-76. [CrossRef] [PubMed]

139. Zoete, V.; Grosdidier, A.; Michielin, O. Peroxisome proliferator-activated receptor structures: Ligand specificity, molecular switch and interactions with regulators. Biochim. Biophys. Acta 2007, 1771, 915-925. [CrossRef] [PubMed]

140. Shin, S.J.; Lim, J.H.; Chung, S.; Youn, D.Y.; Chung, H.W.; Kim, H.W.; Lee, J.-H.; Chang, Y.S.; Park, C.W.; et al. Peroxisome proliferator-activated receptor-alpha activator fenofibrate prevents high-fat diet-induced renal lipotoxicity in spontaneously hypertensive rats. Hypertens. Res. 2009, 32, 835-845. [CrossRef] [PubMed]

141. Gelosa, P.; Banfi, C.; Gianella, A.; Brioschi, M.; Pignieri, A.; Nobili, E.; Castiglioni, L.; Cimino, M.; Tremoli, E.; Sironi, L. Peroxisome proliferator-activated receptor $\alpha$ agonism prevents renal damage and the oxidative stress and inflammatory processes affecting the brains of stroke-prone rats. J. Pharmacol. Exp. Ther. 2010, 335, 324-331. [CrossRef] [PubMed]

142. Rosenson, R.S.; Wolff, D.A.; Huskin, A.L.; Helenowski, I.B.; Rademaker, A.W. Fenofibrate therapy ameliorates fasting and postprandial lipoproteinemia, oxidative stress, and the inflammatory response in subjects with hypertriglyceridemia and the metabolic syndrome. Diabetes Care 2007, 30, 1945-1951. [CrossRef] [PubMed] 
143. Sun, Y.; Alexander, S.P.H.; Kendall, D.A.; Bennett, A.J. Cannabinoids and PPARalpha signalling. Biochem. Soc. Trans. 2006, 34, 1095-1097. [CrossRef] [PubMed]

144. Bouaboula, M.; Hilairet, S.; Marchand, J.; Fajas, L.; Le Fur, G.; Casellas, P. Anandamide induced PPARgamma transcriptional activation and 3T3-L1 preadipocyte differentiation. Eur. J. Pharmacol. 2005, 517, 174-181. [CrossRef] [PubMed]

145. Du, H.; Chen, X.; Zhang, J.; Chen, C. Inhibition of COX-2 expression by endocannabinoid 2-arachidonoylglycerol is mediated via PPAR- $\gamma$. Br. J. Pharmacol. 2011, 163, 1533-1549. [CrossRef] [PubMed]

146. Baker, D.; Pryce, G.; Davies, W.L.; Hiley, C.R. In silico patent searching reveals a new cannabinoid receptor. Trends Pharmacol. Sci. 2006, 27, 1-4. [CrossRef] [PubMed]

147. Shah, U.; Kowalski, T.J. GPR119 agonists for the potential treatment of type 2 diabetes and related metabolic disorders. Vitam. Horm. 2010, 84, 415-448. [CrossRef] [PubMed]

148. Lauckner, J.E.; Jensen, J.B.; Chen, H.Y.; Lu, H.C.; Hille, B.; Mackie, K. GPR55 is a cannabinoid receptor that increases intracellular calcium and inhibits M current. Proc. Natl. Acad. Sci. USA 2008, 105, 2699-2704. [CrossRef] [PubMed]

149. Ohno-Shosaku, T.; Maejima, T.; Kano, M. Endogenous cannabinoids mediate retrograde signals from depolarized postsynaptic neurons to presynaptic terminals. Neuron 2001, 29, 729-738. [CrossRef]

150. Hashimotodani, Y.; Ohno-Shosaku, T.; Kano, M. Endocannabinoids and synaptic function in the CNS. Neuroscientist 2007, 13, 127-137. [CrossRef] [PubMed]

151. Oddi, S.; Fezza, F.; Pasquariello, N.; De Simone, C.; Rapino, C.; Dainese, E.; Finazzi-Agrò, A.; Maccarrone, M. Evidence for the intracellular accumulation of anandamide in adiposomes. Cell. Mol. Life Sci. 2008, 65, 840-850. [CrossRef] [PubMed]

152. Di Marzo, V.; Fontana, A.; Cadas, H.; Schinelli, S.; Cimino, G.; Schwartz, J.C.; Piomelli, D. Formation and inactivation of endogenous cannabinoid anandamide in central neurons. Nature 1994, 372, 686-691. [CrossRef] [PubMed]

153. Wang, J.; Ueda, N. Biology of endocannabinoid synthesis system. Prostaglandins Other Lipid Mediat. 2009, 89, 112-119. [CrossRef] [PubMed]

154. Cravatt, B.F.; Giang, D.K.; Mayfield, S.P.; Boger, D.L.; Lerner, R.A.; Gilula, N.B. Molecular characterization of an enzyme that degrades neuromodulatory fatty-acid amides. Nature 1996, 384, 83-87. [CrossRef] [PubMed]

155. Seillier, A.; Advani, T.; Cassano, T.; Hensler, J.G.; Giuffrida, A. Inhibition of fatty-acid amide hydrolase and CB1 receptor antagonism differentially affect behavioural responses in normal and PCP-treated rats. Int. J. Neuropsychopharmacol. 2010, 13, 373-386. [CrossRef] [PubMed]

156. Bedse, G.; Colangeli, R.; Lavecchia, A.M.; Romano, A.; Altieri, F.; Cifani, C.; Cassano, T.; Gaetani, S. Role of the basolateral amygdala in mediating the effects of the fatty acid amide hydrolase inhibitor URB597 on HPA axis response to stress. Eur. Neuropsychopharmacol. 2014, 24, 1511-1523. [CrossRef] [PubMed]

157. Di Marzo, V. Targeting the endocannabinoid system: To enhance or reduce? Nat. Rev. Drug Discov. 2008, 7, 438-455. [CrossRef] [PubMed]

158. Ueda, N.; Tsuboi, K.; Uyama, T. N-acylethanolamine metabolism with special reference to N-acylethanolamine-hydrolyzing acid amidase (NAAA). Prog. Lipid Res. 2010, 49, 299-315. [CrossRef] [PubMed]

159. Ueda, N.; Tsuboi, K.; Uyama, T.; Ohnishi, T. Biosynthesis and degradation of the endocannabinoid 2-arachidonoylglycerol. Biofactors 2011, 37, 1-7. [CrossRef] [PubMed]

160. Rouzer, C.A.; Marnett, L.J. Endocannabinoid oxygenation by cyclooxygenases, lipoxygenases, andcytochromes P450: Cross-talk between the eicosanoid and endocannabinoid signaling pathways. Chem. Rev. 2011, 111, 5899-5921. [CrossRef] [PubMed]

161. Bradshaw, H.B.; Walker, J.M. The expanding field of cannabimimetic and related lipid mediators. Br. J. Pharmacol. 2009, 144, 459-465. [CrossRef] [PubMed]

162. Berdyshev, E.V.; Schmid, P.C.; Krebsbach, R.J.; Hillard, C.J.; Huang, C.; Chen, N.; Dong, Z.; Schmid, H.H. Cannabinoid-receptor-independent cell signalling by $N$-acylethanolamines. Biochem. J. 2001, 360, 67-75. [CrossRef] [PubMed]

163. Azari, E.K.; Ramachandran, D.; Weibel, S.; Arnold, M.; Romano, A.; Gaetani, S.; Langhans, W.; Mansouri, A. Vagal afferents are not necessary for the satiety effect of the gut lipid messenger oleoylethanolamide. Am. J. Physiol. Regul. Integr. Comp. Physiol. 2014, 307, R167-R178. [CrossRef] [PubMed] 
164. Provensi, G.; Coccurello, R.; Umehara, H.; Munari, L.; Giacovazzo, G.; Galeotti, N.; Nosi, D.; Gaetani, S.; Romano, A.; Moles, A.; et al. Satiety factor oleoylethanolamide recruits the brain histaminergic system to inhibit food intake. Proc. Natl. Acad. Sci. USA 2014, 111, 11527-11532. [CrossRef] [PubMed]

165. Romano, A.; Cassano, T.; Tempesta, B.; Cianci, S.; Dipasquale, P.; Coccurello, R.; Cuomo, V.; Gaetani, S. The satiety signal oleoylethanolamide stimulates oxytocin neurosecretion from rat hypothalamic neurons. Peptides 2013, 49, 21-26. [CrossRef] [PubMed]

166. Romano, A.; Karimian Azari, E.; Tempesta, B.; Mansouri, A.; Micioni Di Bonaventura, M.V.; Ramachandran, D.; Lutz, T.A.; Bedse, G.; Langhans, W.; Gaetani, S. High dietary fat intake influences the activation of specific hindbrain and hypothalamic nuclei by the satiety factor oleoylethanolamide. Physiol. Behav. 2014, 136, 55-62. [CrossRef] [PubMed]

167. Romano, A.; Coccurello, R.; Giacovazzo, G.; Bedse, G.; Moles, A.; Gaetani, S. Oleoylethanolamide: A novel potential pharmacological alternative to cannabinoid antagonists for the control of appetite. Biomed. Res. Int. 2014, 2014, 203425. [CrossRef] [PubMed]

168. Gaetani, S.; Kaye, W.H.; Cuomo, V.; Piomelli, D. Role of endocannabinoids and their analogues in obesity and eating disorders. Eat. Weight Disord. 2008, 13, e42-e48. [CrossRef] [PubMed]

169. Fidaleo, M.; Fanelli, F.; Ceru, M.P.; Moreno, S. Neuroprotective properties of peroxisome proliferatoractivated receptor alpha (PPAR $\alpha)$ and its lipid ligands. Curr. Med. Chem. 2014, 21, 2803-2821. [CrossRef] [PubMed]

170. Bedse, G.; Romano, A.; Lavecchia, A.M.; Cassano, T.; Gaetani, S. The role of endocannabinoid signaling in the molecular mechanisms of neurodegeneration in Alzheimer's disease. J. Alzheimer Dis. 2015, 43, 1115-1136. [CrossRef] [PubMed]

171. Scuderi, C.; Bronzuoli, M.R.; Facchinetti, R.; Pace, L.; Ferraro, L.; Broad, K.D.; Serviddio, G.; Bellanti, F.; Palombelli, G.; Carpinelli, G.; et al. Ultramicronized palmitoylethanolamide rescues learning and memory impairments in a triple transgenic mouse model of Alzheimer's disease by exerting anti-inflammatory and neuroprotective effects. Transl. Psychiatry 2018, 8, 32. [CrossRef] [PubMed]

172. Bronzuoli, M.R.; Facchinetti, R.; Steardo, L., Jr.; Romano, A.; Stecca, C.; Passarella, S.; Steardo, L.; Cassano, T.; Scuderi, C. Palmitoylethanolamide Dampens Reactive Astrogliosis and Improves Neuronal Trophic Support in a Triple Transgenic Model of Alzheimer's Disease: In Vitro and In Vivo Evidence. Oxid. Med. Cell. Longev. 2018, 2018, 4720532. [CrossRef] [PubMed]

173. Hanus, L.; Abu-Lafi, S.; Fride, E.; Breuer, A.; Vogel, Z.; Shalev, D.E.; Kustanovich, I.; Mechoulam, R. 2-arachidonyl glyceryl ether, an endogenous agonist of the cannabinoid CB1 receptor. Proc. Natl. Acad. Sci. USA 2001, 98, 3662-3665. [CrossRef] [PubMed]

174. Porter, A.C.; Sauer, J.M.; Knierman, M.D.; Becker, G.W.; Berna, M.J.; Bao, J.; Nomikos, G.G.; Carter, P.; Bymaster, F.P.; Leese, A.B.; et al. Characterization of a novel endocannabinoid, virodhamine, with antagonist activity at the CB1 receptor. J. Pharmacol. Exp. Ther. 2002, 301, 1020-1024. [CrossRef] [PubMed]

175. Sharir, H.; Console-Bram, L.; Mundy, C.; Popoff, S.N.; Kapur, A.; Abood, M.E. The Endocannabinoids Anandamide and Virodhamine Modulate the Activity of the Candidate Cannabinoid Receptor GPR55. J. Neuroimmune Pharmacol. 2012, 7, 856-865. [CrossRef] [PubMed]

176. Kohno, M.; Hasegawa, H.; Inoue, A.; Muraoka, M.; Miyazaki, T.; Oka, K.; Yasukawa, M. Identification of $\mathrm{N}$-arachidonylglycine as the endogenous ligand for orphan G-protein-coupled receptor GPR18. Biochem. Biophys. Res. Commun. 2006, 347, 827-832. [CrossRef] [PubMed]

177. Lipina, C.; Hundal, H.S. Modulation of cellular redox homeostasis by the endocannabinoid system. Open Biol. 2016, 6, 150276. [CrossRef] [PubMed]

178. Horváth, B.; Mukhopadhyay, P.; Kechrid, M.; Patel, V.; Tanchian, G.; Wink, D.A.; Gertsch, J.; Pacher, P. $\beta$-Caryophyllene ameliorates cisplatin-induced nephrotoxicity in a cannabinoid 2 receptor-dependent manner. Free Radic. Biol. Med. 2012, 52, 1325-1333. [CrossRef] [PubMed]

179. Mukhopadhyay, P.; Pan, H.; Rajesh, M.; Batkai, S.; Patel, V.; Harvey-White, J.; Mukhopadhyay, B.; Hasko, G.; Gao, B.; Mackie, K.; et al. CB1 cannabinoid receptors promote oxidative/nitrosative stress, inflammation and cell death in a murine nephropathy model. Br. J. Pharmacol. 2010, 160, 657-668. [CrossRef] [PubMed]

180. Mukhopadhyay, P.; Rajesh, M.; Pan, H.; Patel, V.; Mukhopadhyay, B.; Bátkai, S.; Gao, B.; Haskó, G.; Pacher, P. Cannabinoid-2 receptor limits inflammation, oxidative/nitrosative stress, and cell death in nephropathy. Free Radic. Biol. Med. 2010, 48, 457-467. [CrossRef] [PubMed] 
181. Mukhopadhyay, P.; Baggelaar, M.; Erdelyi, K.; Cao, Z.; Cinar, R.; Fezza, F.; Ignatowska-Janlowska, B.; Wilkerson, J.; van Gils, N.; Hansen, T.; et al. The novel, orally available and peripherally restricted selective cannabinoid CB2 receptor agonist LEI-101 prevents cisplatin-induced nephrotoxicity. Br. J. Pharmacol. 2016, 173, 446-458. [CrossRef] [PubMed]

182. Bedse, G.; Di Domenico, F.; Serviddio, G.; Cassano, T. Aberrant insulin signaling in Alzheimer's disease: Current knowledge. Front. Neurosci. 2015, 9, 204. [CrossRef] [PubMed]

183. Barone, E.; Di Domenico, F.; Cassano, T.; Arena, A.; Tramutola, A.; Lavecchia, M.A.; Coccia, R.; Butterfield, D.A.; Perluigi, M. Impairment of biliverdin reductase-A promotes brain insulin resistance in Alzheimer disease: A new paradigm. Free Radic. Biol. Med. 2016, 91, 127-142. [CrossRef] [PubMed]

184. Pardeshi, R.; Bolshette, N.; Gadhave, K.; Ahire, A.; Ahmed, S.; Cassano, T.; Gupta, V.B.; Lahkar, M. Insulin signaling: An opportunistic target to minify the risk of Alzheimer's disease. Psychoneuroendocrinology 2017, 83, 159-171. [CrossRef] [PubMed]

185. Gruden, G.; Barutta, F.; Kunos, G.; Pacher, P. Role of the endocannabinoid system in diabetes and diabetic complications. Br. J. Pharmacol. 2016, 173, 1116-1127. [CrossRef] [PubMed]

186. Pacher, P.; Hasko, G. Endocannabinoids and cannabinoid receptors in ischaemia-reperfusion injury and preconditioning. Br. J. Pharmacol. 2008, 153, 252-262. [CrossRef] [PubMed]

187. Silvestri, C.; Ligresti, A.; Di Marzo, V. Peripheral effects of the endocannabinoid system in energy homeostasis: Adipose tissue, liver and skeletal muscle. Rev. Endocr. Metab. Disord. 2011, 12, 153-162. [CrossRef] [PubMed]

188. Muriel, P. Role of free radicals in liver diseases. Hepatol. Int. 2009, 3, 526-536. [CrossRef] [PubMed]

189. Mukhopadhyay, P.; Horváth, B.; Rajesh, M.; Matsumoto, S.; Saito, K.; Bátkai, S.; Patel, V.; Tanchian, G.; Gao, R.Y.; Cravatt, B.F.; et al. Fatty acid amide hydrolase is a key regulator of endocannabinoid-induced myocardial tissue injury. Free Radic. Biol. Med. 2011, 50, 179-195. [CrossRef] [PubMed]

190. Rajesh, M.; Mukhopadhyay, P.; Haskó, G.; Liaudet, L.; Mackie, K.; Pacher, P. Cannabinoid-1 receptor activation induces reactive oxygen species-dependent and -independent mitogen-activated protein kinase activation and cell death in human coronary artery endothelial cells. Br. J. Pharmacol. 2010, 160, 688-700. [CrossRef] [PubMed]

191. Bátkai, S.; Osei-Hyiaman, D.; Pan, H.; El-Assal, O.; Rajesh, M.; Mukhopadhyay, P.; Hong, F.; Harvey-White, J.; Jafri, A.; Haskó, G.; et al. Cannabinoid-2 receptor mediates protection against hepatic ischemia/reperfusion injury. FASEB J. 2007, 21, 1788-1800. [CrossRef] [PubMed]

192. Rajesh, M.; Pan, H.; Mukhopadhyay, P.; Batkai, S.; Osei-Hyiaman, D.; Hasko, G.; Liaudet, L.; Gao, B.; Pacher, P. Cannabinoid-2 receptor agonist HU-308 protects against hepatic ischemia/reperfusion injury by attenuating oxidative stress, inflammatory response, and apoptosis. J. Leukoc. Biol. 2007, 82, 1382-1389. [CrossRef] [PubMed]

193. Montecucco, F.; Lenglet, S.; Braunersreuther, V.; Burger, F.; Pelli, G.; Bertolotto, M.; Mach, F.; Steffens, S. $\mathrm{CB}_{2}$ cannabinoid receptor activation is cardioprotective in a mouse model of ischemia/reperfusion. J. Mol. Cell. Cardiol. 2009, 46, 612-620. [CrossRef] [PubMed]

194. Zhang, M.; Adler, M.W.; Abood, M.E.; Ganea, D.; Jallo, J.; Tuma, R.F. CB $_{2}$ receptor activation attenuates microcirculatory dysfunction during cerebral ischemic/reperfusion injury. Microvasc. Res. 2009, 78, 86-94. [CrossRef] [PubMed]

195. Murikinati, S.; Juttler, E.; Keinert, T.; Ridder, D.A.; Muhammad, S.; Waibler, Z.; Ledent, C.; Zimmer, A.; Kalinke, U.; Schwaninger, M. Activation of cannabinoid 2 receptors protects against cerebral ischemia by inhibiting neutrophil recruitment. FASEB J. 2009. [CrossRef] [PubMed]

196. Steffens, S.; Veillard, N.R.; Arnaud, C.; Pelli, G.; Burger, F.; Staub, C.; Karsak, M.; Zimmer, A.; Frossard, J.L.; Mach, F. Low dose oral cannabinoid therapy reduces progression of atherosclerosis in mice. Nature 2005, 434, 782-786. [CrossRef] [PubMed]

197. Rajesh, M.; Mukhopadhyay, P.; Batkai, S.; Hasko, G.; Liaudet, L.; Huffman, J.W.; Csiszar, A.; Ungvari, Z.; Mackie, K.; Chatterjee, S.; et al. $\mathrm{CB}_{2}$-receptor stimulation attenuates TNF-alpha-induced human endothelial cell activation, transendothelial migration of monocytes, and monocyte-endothelial adhesion. Am. J. Physiol. Heart Circ. Physiol. 2007, 293, H2210-H2218. [CrossRef] [PubMed]

198. Pacher, P.; Mechoulam, R. Is lipid signaling through cannabinoid 2 receptors part of a protective system? Prog. Lipid Res. 2011, 50, 193-211. [CrossRef] [PubMed] 
199. Matthews, A.T.; Lee, J.H.; Borazjani, A.; Mangum, L.C.; Hou, X.; Ross, M.K. Oxyradical stress increases the biosynthesis of 2-arachidonoylglycerol: Involvement of NADPH oxidase. Am. J. Physiol. Cell Physiol. 2016, 311, C960-C974. [CrossRef] [PubMed]

200. Hoyer, F.F.; Steinmetz, M.; Zimmer, S.; Becker, A.; Lütjohann, D.; Buchalla, R.; Zimmer, A.; Nickenig, G. Atheroprotection via cannabinoid receptor-2 is mediated by circulating and vascular cells in vivo. J. Mol. Cell. Cardiol. 2011, 51, 1007-1014. [CrossRef] [PubMed]

201. Tiyerili, V.; Zimmer, S.; Jung, S.; Wassmann, K.; Naehle, C.P.; Lütjohann, D.; Zimmer, A.; Nickenig, G.; Wassmann, $\mathrm{S} . \mathrm{CB}_{1}$ receptor inhibition leads to decreased vascular AT1 receptor expression, inhibition of oxidative stress and improved endothelial function. Basic Res. Cardiol. 2010, 105, 465-477. [CrossRef] [PubMed]

202. Zolese, G.; Bacchetti, T.; Masciangelo, S.; Ragni, L.; Ambrosi, S.; Ambrosini, A.; Marini, M.; Ferretti, G. Effect of acylethanolamides on lipid peroxidation and paraoxonase activity. Biofactors 2008, 33, 201-209. [CrossRef] [PubMed]

203. Gulaya, N.M.; Kuzmenko, A.I.; Margitich, V.M.; Govseeva, N.M.; Melnichuk, S.D.; Goridko, T.M.; Zhukov, A.D. Long-chain $N$-acylethanolamines inhibit lipid peroxidation in rat liver mitochondria under acute hypoxic hypoxia. Chem. Phys. Lipids 1998, 97, 49-54. [CrossRef]

204. Poli, G.; Albano, E.; Dianzani, M.U. The role of lipid peroxidation in liver damage. Chem. Phys. Lipids 1987, 45, 117-142. [CrossRef]

205. Emerit, J.; Chaudiere, J. Free Radicals and Lipid Peroxidation in Cell Biology; Handbook of Free Radicals and Antioxidants in Biomedicine; CRC Press: Boca Raton, FL, USA, 1989; pp. 177-185.

206. Gulaya, N.M.; Melnik, A.A.; Balkov, D.I.; Volkov, G.L.; Vysotskiy, M.V.; Vaskovsky, V.E. The effect of long-chain $\mathrm{N}$-acylethanolamines on some membrane-associated functions of neuroblastoma C1300 N18 cells. Biochim. Biophys. Acta 1993, 1152, 280-288. [CrossRef]

207. Parinandi, N.L.; Schmid, H.H. Effects of long-chain $N$-acylethanolamines on lipid peroxidation in cardiac mitochondria. FEBS Lett. 1988, 237, 49-52. [CrossRef]

208. Zolese, G.; Bacchetti, T.; Ambrosini, A.; Wozniak, M.; Bertoli, E.; Ferretti, G. Increased plasma concentrations of palmitoylethanolamide, an endogenous fatty acid amide, affect oxidative damage of human low-density lipoproteins: An in vitro study. Atherosclerosis 2005, 182, 47-55. [CrossRef] [PubMed]

209. Biernacki, M.; Łuczaj, W.; Gegotek, A.; Toczek, M.; Bielawska, K.; Skrzydlewska, E. Crosstalk between liver antioxidant and the endocannabinoid systems after chronic administration of the FAAH inhibitor, URB597, to hypertensive rats. Toxicol. Appl. Pharmacol. 2016, 301, 31-41. [CrossRef] [PubMed]

210. Di Marzo, V.; Maccarrone, M. FAAH and anandamide: Is 2-AG really the odd one out? Trends Pharmacol. Sci. 2008, 29, 229-233. [CrossRef] [PubMed]

211. Basu, P.P.; Aloysius, M.M.; Shah, N.J.; Brown, R.S., Jr. Review article: The endocannabinoid system in liver disease, a potential therapeutic target. Aliment. Pharmacol. Ther. 2014, 39, 790-801. [CrossRef] [PubMed]

212. DeLeve, L.D.; Wang, X.; Kanel, G.C.; Atkinson, R.D.; McCuskey, R.S. Prevention of hepatic fibrosis in a murine model of metabolic syndrome with nonalcoholic steatohepatitis. Am. J. Pathol. 2008, 173, 993-1001. [CrossRef] [PubMed]

213. Mallat, A.; Teixeira-Clerc, F.; Lotersztajn, S. Cannabinoid signaling and liver therapeutics. J. Hepatol. 2013, 59, 891-896. [CrossRef] [PubMed]

214. Simonian, N.A.; Coyle, J.T. Oxidative stress in neurodegenerative diseases. Annu. Rev. Pharmacol. Toxicol. 1996, 36, 83-106. [CrossRef] [PubMed]

215. Behl, C. Alzheimer's disease and oxidative stress: Implications for novel therapeutic approaches. Prog. Neurobiol. 1999, 57, 301-323. [CrossRef]

216. Bedse, G.; Romano, A.; Cianci, S.; Lavecchia, A.M.; Lorenzo, P.; Elphick, M.R.; Laferla, F.M.; Vendemiale, G.; Grillo, C.; Altieri, F.; et al. Altered expression of the CB1 cannabinoid receptor in the triple transgenic mouse model of Alzheimer's disease. J. Alzheimer Dis. 2014, 40, 701-712. [CrossRef] [PubMed]

217. Gatta, E.; Lefebvre, T.; Gaetani, S.; dos Santos, M.; Marrocco, J.; Mir, A.M.; Cassano, T.; Maccari, S.; Nicoletti, F.; Mairesse, J. Evidence for an imbalance between tau O-GlcNAcylation and phosphorylation in the hippocampus of a mouse model of Alzheimer's disease. Pharmacol. Res. 2016, 105, 186-197. [CrossRef] [PubMed]

218. Milton, N.G. Role of hydrogen peroxide in the aetiology of Alzheimer's disease: Implications for treatment. Drugs Aging 2004, 21, 81-100. [CrossRef] [PubMed] 
219. Ano, Y.; Sakudo, A.; Kimata, T.; Uraki, R.; Sugiura, K.; Onodera, T. Oxidative damage to neurons caused by the induction of microglial NADPH oxidase in encephalomyocarditis virus infection. Neurosci. Lett. 2010, 469, 39-43. [CrossRef] [PubMed]

220. Ye, Q.; Huang, B.; Zhang, X.; Zhu, Y.; Chen, X. Astaxanthin protects against MPP+-induced oxidative stress in PC12 cells via the HO-1/NOX2 axis. BMC Neurosci. 2012, 13, 156. [CrossRef] [PubMed]

221. Jia, J.; Ma, L.; Wu, M.; Zhang, L.; Zhang, X.; Zhai, Q.; Jiang, T.; Wang, Q.; Xiong, L. Anandamide protects HT22 cells exposed to hydrogen peroxide by inhibiting CB1 receptor-mediated type 2 NADPH oxidase. Oxid. Med. Cell. Longev. 2014, 2014, 893516. [CrossRef] [PubMed]

222. Chung, Y.C.; Bok, E.; Huh, S.H.; Park, J.Y.; Yoon, S.H.; Kim, S.R.; Kim, Y.S.; Maeng, S.; Park, S.H.; Jin, B.K. Cannabinoid receptor type 1 protects nigrostriatal dopaminergic neurons against MPTP neurotoxicity by inhibiting microglial activation. J. Immunol. 2011, 187, 6508-6517. [CrossRef] [PubMed]

223. Cassano, T.; Calcagnini, S.; Pace, L.; De Marco, F.; Romano, A.; Gaetani, S. Cannabinoid Receptor 2 Signaling in Neurodegenerative Disorders: From Pathogenesis to a Promising Therapeutic Target. Front. Neurosci. 2017, 11, 30. [CrossRef] [PubMed]

224. Jayant, S.; Sharma, B.M.; Bansal, R.; Sharma, B. Pharmacological benefits of selective modulation of cannabinoid receptor type 2 (CB2) in experimental Alzheimer's disease. Pharmacol. Biochem. Behav. 2016, 140, 39-50. [CrossRef] [PubMed]

225. Koppel, J.; Vingtdeux, V.; Marambaud, P.; d'Abramo, C.; Jimenez, H.; Stauber, M.; Friedman, R.; Davies, P. CB2 receptor deficiency increases amyloid pathology and alters tau processing in a transgenic mouse model of Alzheimer's disease. Mol. Med. 2014, 20, 29-36. [CrossRef] [PubMed]

226. Chen, R.; Zhang, J.; Wu, Y.; Wang, D.; Feng, G.; Tang, Y.P.; Teng, Z.; Chen, C. Monoacylglycerol lipase is a therapeutic target for Alzheimer's disease. Cell Rep. 2012, 2, 1329-1339. [CrossRef] [PubMed]

227. Paloczi, J.; Varga, Z.V.; Hasko, G.; Pacher, P. Neuroprotection in Oxidative Stress-Related Neurodegenerative Diseases: Role of Endocannabinoid System Modulation. Antioxid. Redox Signal. 2018, 29, 75-108. [CrossRef] [PubMed]

228. Pihlaja, R.; Takkinen, J.; Eskola, O.; Vasara, J.; López-Picón, F.R.; Haaparanta-Solin, M.; Rinne, J.O. Monoacylglycerol lipase inhibitor JZL184 reduces neuroinflammatory response in APdE9 mice and in adult mouse glial cells. J. Neuroinflamm. 2015, 12, 81. [CrossRef] [PubMed]

229. Kessiova, M.; Alexandrova, A.; Georgieva, A.; Kirkova, M.; Todorov, S. In vitro effects of CB1 receptor ligands on lipid peroxidation and antioxidant defense systems in the rat brain. Pharmacol. Rep. 2006, 58, 870-875. [PubMed]

230. Sun, H.J.; Lu, Y.; Wang, H.W.; Zhang, H.; Wang, S.R.; Xu, W.Y.; Fu, H.L.; Yao, X.Y.; Yang, F.; Yuan, H.B. Activation of Endocannabinoid Receptor 2 as a Mechanism of Propofol Pretreatment-Induced Cardioprotection against Ischemia-Reperfusion Injury in Rats. Oxid. Med. Cell. Longev. 2017, 2017, 2186383. [CrossRef] [PubMed]

231. Hayn, M.H.; Ballesteros, I.; de Miguel, F.; Coyle, C.H.; Tyagi, S.; Yoshimura, N.; Chancellor, M.B.; Tyagi, P. Functional and immunohistochemical characterization of CB1 and CB2 receptors in rat bladder. Urology 2008, 72, 1174-1178. [CrossRef] [PubMed]

232. Wang, Z.Y.; Wang, P.; Bjorling, D.E. Activation of cannabinoid receptor 2 inhibits experimental cystitis. Am. J. Physiol. Regul. Integr. Comp. Physiol. 2013, 304, R846-R853. [CrossRef] [PubMed]

233. Hermanson, D.J.; Marnett, L.J. Cannabinoids endocannabinoids, and cancer. Cancer Metastasis Rev. 2011, 30, 599-612. [CrossRef] [PubMed]

234. Ravi, J.; Sneh, A.; Shilo, K.; Nasser, M.W.; Ganju, R.K. FAAH inhibition enhances anandamide mediated anti-tumorigenic effects in non-small cell lung cancer by downregulating the EGF/EGFR pathway. Oncotarget 2014, 5, 2475-2486. [CrossRef] [PubMed]

235. Clapham, D.E.; Runnels, L.W.; Strübing, C. The TRP ion channel family. Nat. Rev. Neurosci. 2001, 2, 387-396. [CrossRef] [PubMed]

236. Harteneck, C.; Plant, T.D.; Schultz, G. From worm to man: Three subfamilies of TRP channels. Trends Neurosci. 2000, 23, 159-166. [CrossRef]

237. Wu, L.J.; Sweet, T.B.; Clapham, D.E. International Union of Basic and Clinical Pharmacology. LXXVI. Current progress in the mammalian TRP ion channel family. Pharmacol. Rev. 2010, 62, 381-404. [CrossRef] [PubMed]

238. Venkatachalam, K.; Montell, C. TRP channels. Annu. Rev. Biochem. 2007, 76, 387-417. [CrossRef] [PubMed] 
239. Moran, M.M.; Xu, H.; Clapham, D.E. TRP ion channels in the nervous system. Curr. Opin. Neurobiol. 2004, 14, 362-369. [CrossRef] [PubMed]

240. Desai, B.N.; Clapham, D.E. TRP channels and mice deficient in TRP channels. Pflugers Arch. 2005, 451, 11-18. [CrossRef] [PubMed]

241. Vriens, J.; Appendino, G.; Nilius, B. Pharmacology of vanilloid transient receptor potential cation channels. Mol. Pharmacol. 2009, 75, 1262-1279. [CrossRef] [PubMed]

242. Cavanaugh, D.J.; Chesler, A.T.; Jackson, A.C.; Sigal, Y.M.; Yamanaka, H.; Grant, R.; O’Donnell, D.; Nicoll, R.A.; Shah, N.M.; Julius, D.; et al. Trpv1 reporter mice reveal highly restricted brain distribution and functional expression in arteriolar smooth muscle cells. J. Neurosci. 2011, 31, 5067-5077. [CrossRef] [PubMed]

243. Caterina, M.J.; Schumacher, M.A.; Tominaga, M.; Rosen, T.A.; Levine, J.D.; Julius, D. The capsaicin receptor: A heat-activated ion channel in the pain pathway. Nature 1997, 389, 816-824. [CrossRef] [PubMed]

244. Tominaga, M.; Caterina, M.J.; Malmberg, A.B.; Rosen, T.A.; Gilbert, H.; Skinner, K.; Raumann, B.E.; Basbaum, A.I.; Julius, D. The cloned capsaicin receptor integrates multiple pain-producing stimuli. Neuron 1998, 21, 531-543. [CrossRef]

245. Jordt, S.E.; Tominaga, M.; Julius, D. Acid potentiation of the capsaicin receptor determined by a key extracellular site. Proc. Natl. Acad. Sci. USA 2000, 97, 8134-8139. [CrossRef] [PubMed]

246. Iida, T.; Moriyama, T.; Kobata, K.; Morita, A.; Murayama, N.; Hashizume, S.; Fushiki, T.; Yazawa, S.; Watanabe, T.; Tominaga, M. TRPV1 activation and induction of nociceptive response by a non-pungent capsaicin-like compound, capsiate. Neuropharmacology 2003, 44, 958-967. [CrossRef]

247. Blednov, Y.A.; Harris, R.A. Deletion of vanilloid receptor (TRPV1) in mice alters behavioral effects of ethanol. Neuropharmacology 2009, 56, 814-820. [CrossRef] [PubMed]

248. Ellingson, J.M.; Silbaugh, B.C.; Brasser, S.M. Reduced oral ethanol avoidance in mice lacking transient receptor potential channel vanilloid receptor 1. Behav. Genet. 2009, 39, 62-72. [CrossRef] [PubMed]

249. Ahern, G.P. Activation of TRPV1 by the satiety factor oleoylethanolamide. J. Biol. Chem. 2003, 278, 30429-30434. [CrossRef] [PubMed]

250. Huang, S.M.; Bisogno, T.; Trevisani, M.; Al-Hayani, A.; De Petrocellis, L.; Fezza, F.; Tognetto, M.; Petros, T.J.; Krey, J.F.; Chu, C.J.; et al. An endogenous capsaicin-like substance with high potency at recombinant and native vanilloid VR1 receptors. Proc. Natl. Acad. Sci. USA 2002, 99, 8400-8405. [CrossRef] [PubMed]

251. Chu, C.J.; Huang, S.M.; De Petrocellis, L.; Bisogno, T.; Ewing, S.A.; Miller, J.D.; Zipkin, R.E.; Daddario, N.; Appendino, G.; Di Marzo, V.; et al. N-oleoyldopamine, a novel endogenous capsaicin-like lipid that produces hyperalgesia. J. Biol. Chem. 2003, 278, 13633-13639. [CrossRef] [PubMed]

252. Hwang, S.W.; Cho, H.; Kwak, J.; Lee, S.Y.; Kang, C.J.; Jung, J.; Cho, S.; Min, K.H.; Suh, Y.G.; Kim, D.; et al. Direct activation of capsaicin receptors by products of lipoxygenases: Endogenous capsaicin-like substances. Proc. Natl. Acad. Sci. USA 2000, 97, 6155-6160. [CrossRef] [PubMed]

253. Numazaki, M.; Tominaga, T.; Takeuchi, K.; Murayama, N.; Toyooka, H.; Tominaga, M. Structural determinant of TRPV1 desensitization interacts with calmodulin. Proc. Natl. Acad. Sci. USA 2003, 100, 8002-8006. [CrossRef] [PubMed]

254. Rosenbaum, T.; Gordon-Shaag, A.; Munari, M.; Gordon, S.E. Ca ${ }^{2+} /$ calmodulin modulates TRPV1 activation by capsaicin. J. Gen. Physiol. 2004, 123, 53-62. [CrossRef] [PubMed]

255. Lishko, P.V.; Procko, E.; Jin, X.; Phelps, C.B.; Gaudet, R. The ankyrin repeats of TRPV1 bind multiple ligands and modulate channel sensitivity. Neuron 2007, 54, 905-918. [CrossRef] [PubMed]

256. Kwon, Y.; Hofmann, T.; Montell, C. Integration of phosphoinositide- and calmodulin-mediated regulation of TRPC6. Mol. Cell 2007, 25, 491-503. [CrossRef] [PubMed]

257. Premkumar, L.S.; Ahern, G.P. Induction of vanilloid receptor channel activity by protein kinase C. Nature 2000, 408, 985-990. [CrossRef] [PubMed]

258. De Petrocellis, L.; Harrison, S.; Bisogno, T.; Tognetto, M.; Brandi, I.; Smith, G.D.; Creminon, C.; Davis, J.B.; Geppetti, P.; Di Marzo, V. The vanilloid receptor (VR1)-mediated effects of anandamide are potently enhanced by the cAMP-dependent protein kinase. J. Neurochem. 2001, 77, 1660-1663. [CrossRef] [PubMed]

259. Docherty, R.J.; Yeats, J.C.; Bevan, S.; Boddeke, H.W. Inhibition of calcineurin inhibits the desensitization of capsaicin-evoked currents in cultured dorsal root ganglion neurones from adult rats. Pflugers Arch. 1996, 431, 828-837. [CrossRef] [PubMed] 
260. Birder, L.A.; Nakamura, Y.; Kiss, S.; Nealen, M.L.; Barrick, S.; Kanai, A.J.; Wang, E.; Ruiz, G.; De Groat, W.C.; Apodaca, G.; et al. Altered urinary bladder function in mice lacking the vanilloid receptor TRPV1. Nat. Neurosci. 2002, 5, 856-860. [CrossRef] [PubMed]

261. Rong, W.; Hillsley, K.; Davis, J.B.; Hicks, G.; Winchester, W.J.; Grundy, D. Jejunal afferent nerve sensitivity in wild-type and TRPV1 knockout mice. J. Physiol. 2004, 560, 867-881. [CrossRef] [PubMed]

262. Treesukosol, Y.; Lyall, V.; Heck, G.L.; DeSimone, J.A.; Spector, A.C. A psychophysical and electrophysiological analysis of salt taste in Trpv1 null mice. Am. J. Physiol. Regul. Integr. Comp. Physiol. 2007, 292, R1799-R1809. [CrossRef] [PubMed]

263. Cagiano, R.; Cassano, T.; Coluccia, A.; Gaetani, S.; Giustino, A.; Steardo, L.; Tattoli, M.; Trabace, L.; Cuomo, V. Genetic factors involved in the effects of developmental low-level alcohol induced behavioral alterations in rats. Neuropsychopharmacology 2002, 26, 191-203. [CrossRef]

264. Geppetti, P.; Materazzi, S.; Nicoletti, P. The transient receptor potential vanilloid 1: Role in airway inflammation and disease. Eur. J. Pharmacol. 2006, 533, 207-214. [CrossRef] [PubMed]

265. Gupta, S.; Sharma, B.; Singh, P.; Sharma, B.M. Modulation of transient receptor potential vanilloid subtype 1 (TRPV1) and norepinephrine transporters (NET) protect against oxidative stress, cellular injury, and vascular dementia. Curr. Neurovasc. Res. 2014, 11, 94-106. [CrossRef] [PubMed]

266. Gupta, S.; Sharma, B. Pharmacological benefits of agomelatine and vanillin in experimental model of Huntington's disease. Pharmacol. Biochem. Behav. 2014, 122, 122-135. [CrossRef] [PubMed]

267. Cao, Z.; Balasubramanian, A.; Marrelli, S.P. Pharmacologically induced hypothermia via TRPV1 channel agonism provides neuroprotection following ischemic stroke when initiated $90 \mathrm{~min}$ after reperfusion. Am. J. Physiol. Regul. Integr. Comp. Physiol. 2014, 306, R149-R156. [CrossRef] [PubMed]

268. Neeper, M.P.; Liu, Y.; Hutchinson, T.L.; Wang, Y.; Flores, C.M.; Qin, N. Activation properties of heterologously expressed mammalian TRPV2: Evidence for species dependence. J. Biol. Chem. 2007, 282, 15894-15902. [CrossRef] [PubMed]

269. Caterina, M.J.; Rosen, T.A.; Tominaga, M.; Brake, A.J.; Julius, D. A capsaicin-receptor homologue with a high threshold for noxious heat. Nature 1999, 398, 436-441. [CrossRef] [PubMed]

270. Szöllősi, A.G.; Oláh, A.; Tóth, I.B.; Papp, F.; Czifra, G.; Panyi, G.; Bíró, T. Transient receptor potential vanilloid-2 mediates the effects of transient heat shock on endocytosis of human monocyte-derived dendritic cells. FEBS Lett. 2013, 587, 1440-1445. [CrossRef] [PubMed]

271. Saito, M.; Hanson, P.I.; Schlesinger, P. Luminal chloride-dependent activation of endosome calcium channels: Patch clamp study of enlarged endosomes. J. Biol. Chem. 2007, 282, 27327-27333. [CrossRef] [PubMed]

272. Abe, K.; Puertollano, R. Role of TRP channels in the regulation of the endosomal pathway. Physiology 2011, 26, 14-22. [CrossRef] [PubMed]

273. Lévêque, M.; Penna, A.; Le Trionnaire, S.; Belleguic, C.; Desrues, B.; Brinchault, G.; Jouneau, S.; Lagadic-Gossmann, D.; Martin-Chouly, C. Phagocytosis depends on TRPV2-mediated calcium influx and requires TRPV2 in lipids rafts: Alteration in macrophages from patients with cystic fibrosis. Sci. Rep. 2018, 8, 4310. [CrossRef] [PubMed]

274. Link, T.M.; Park, U.; Vonakis, B.M.; Raben, D.M.; Soloski, M.J.; Caterina, M.J. TRPV2 has a pivotal role in macrophage particle binding and phagocytosis. Nat. Immunol. 2010, 11, 232-239. [CrossRef] [PubMed]

275. Peier, A.M.; Reeve, A.J.; Andersson, D.A.; Moqrich, A.; Earley, T.J.; Hergarden, A.C.; Story, G.M.; Colley, S.; Hogenesch, J.B.; McIntyre, P.; et al. A heat-sensitive TRP channel expressed in keratinocytes. Science 2002, 296, 2046-2049. [CrossRef] [PubMed]

276. Smith, G.D.; Gunthorpe, M.J.; Kelsell, R.E.; Hayes, P.D.; Reilly, P.; Facer, P.; Wright, J.E.; Jerman, J.C.; Walhin, J.P.; Ooi, L.; Egerton, J.; et al. TRPV3 is a temperature-sensitive vanilloid receptor-like protein. Nature 2002, 418, 186-190. [CrossRef] [PubMed]

277. Moqrich, A.; Hwang, S.W.; Earley, T.J.; Petrus, M.J.; Murray, A.N.; Spencer, K.S.; Andahazy, M.; Story, G.M.; Patapoutian, A. Impaired thermosensation in mice lacking TRPV3, a heat and camphor sensor in the skin. Science 2005, 307, 1468-1472. [CrossRef] [PubMed]

278. Xu, H.; Delling, M.; Jun, J.C.; Clapham, D.E. Oregano, thyme and clove-derived flavors and skin sensitizers activate specific TRP channels. Nat. Neurosci. 2006, 9, 628-635. [CrossRef] [PubMed]

279. Phelps, C.B.; Wang, R.R.; Choo, S.S.; Gaudet, R. Differential regulation of TRPV1, TRPV3, and TRPV4 sensitivity through a conserved binding site on the ankyrin repeat domain. J. Biol. Chem. 2010, 285, 731-740. [CrossRef] [PubMed] 
280. Mandadi, S.; Sokabe, T.; Shibasaki, K.; Katanosaka, K.; Mizuno, A.; Moqrich, A.; Patapoutian, A.; Fukumi-Tominaga, T.; Mizumura, K.; Tominaga, M. TRPV3 in keratinocytes transmits temperature information to sensory neurons via ATP. Pflugers Arch. 2009, 458, 1093-1102. [CrossRef] [PubMed]

281. Huang, S.M.; Lee, H.; Chung, M.K.; Park, U.; Yu, Y.Y.; Bradshaw, H.B.; Coulombe, P.A.; Walker, J.M.; Caterina, M.J. Overexpressed transient receptor potential vanilloid 3 ion channels in skin keratinocytes modulate pain sensitivity via prostaglandin E2. J. Neurosci. 2008, 28, 13727-13737. [CrossRef] [PubMed]

282. Chung, M.K.; Lee, H.; Mizuno, A.; Suzuki, M.; Caterina, M.J. TRPV3 and TRPV4 mediate warmth-evoked currents in primary mouse keratinocytes. J. Biol. Chem. 2004, 279, 21569-21575. [CrossRef] [PubMed]

283. Liedtke, W.; Choe, Y.; Martí-Renom, M.A.; Bell, A.M.; Denis, C.S.; Sali, A.; Hudspeth, A.J.; Friedman, J.M.; Heller, S. Vanilloid receptor-related osmotically activated channel (VR-OAC), a candidate vertebrate osmoreceptor. Cell 2000, 103, 525-535. [CrossRef]

284. Güler, A.D.; Lee, H.; Iida, T.; Shimizu, I.; Tominaga, M.; Caterina, M. Heat-evoked activation of the ion channel, TRPV4. J. Neurosci. 2002, 22, 6408-6414. [CrossRef] [PubMed]

285. Watanabe, H.; Vriens, J.; Prenen, J.; Droogmans, G.; Voets, T.; Nilius, B. Anandamide and arachidonic acid use epoxyeicosatrienoic acids to activate TRPV4 channels. Nature 2003, 424, 434-438. [CrossRef] [PubMed]

286. Vriens, J.; Owsianik, G.; Fisslthaler, B.; Suzuki, M.; Janssens, A.; Voets, T.; Morisseau, C.; Hammock, B.D.; Fleming, I.; Busse, R.; et al. Modulation of the $\mathrm{Ca}^{2}$ permeable cation channel TRPV4 by cytochrome P450 epoxygenases in vascular endothelium. Circ. Res. 2005, 97, 908-915. [CrossRef] [PubMed]

287. Strotmann, R.; Semtner, M.; Kepura, F.; Plant, T.D.; Schöneberg, T. Interdomain interactions control $\mathrm{Ca}^{2+}$-dependent potentiation in the cation channel TRPV4. PLoS ONE 2010, 5, e10580. [CrossRef] [PubMed]

288. White, J.P.; Cibelli, M.; Urban, L.; Nilius, B.; McGeown, J.G.; Nagy, I. TRPV4: Molecular Conductor of a Diverse Orchestra. Physiol. Rev. 2016, 96, 911-973. [CrossRef] [PubMed]

289. Takahashi, N.; Hamada-Nakahara, S.; Itoh, Y.; Takemura, K.; Shimada, A.; Ueda, Y.; Kitamata, M.; Matsuoka, R.; Hanawa-Suetsugu, K.; Senju, Y.; et al. TRPV4 channel activity is modulated by direct interaction of the ankyrin domain to PI $(4,5) \mathrm{P}_{2}$. Nat. Commun. 2014, 5, 4994. [CrossRef] [PubMed]

290. Gao, X.; Wu, L.; O'Neil, R.G. Temperature-modulated diversity of TRPV4 channel gating: Activation by physical stresses and phorbol ester derivatives through protein kinase C-dependent and -independent pathways. J. Biol. Chem. 2003, 278, 27129-27137. [CrossRef] [PubMed]

291. Fan, H.C.; Zhang, X.; McNaughton, P.A. Activation of the TRPV4 ion channel is enhanced by phosphorylation. J. Biol. Chem. 2009, 284, 27884-27891. [CrossRef] [PubMed]

292. Wegierski, T.; Lewandrowski, U.; Müller, B.; Sickmann, A.; Walz, G. Tyrosine phosphorylation modulates the activity of TRPV4 in response to defined stimuli. J. Biol. Chem. 2009, 284, 2923-2933. [CrossRef] [PubMed]

293. Lee, E.J.; Shin, S.H.; Chun, J.; Hyun, S.; Kim, Y.; Kang, S.S. The modulation of TRPV4 channel activity through its Ser 824 residue phosphorylation by SGK1. Anim. Cells Syst. 2010, 14, 99-114. [CrossRef]

294. Delany, N.S.; Hurle, M.; Facer, P.; Alnadaf, T.; Plumpton, C.; Kinghorn, I.; See, C.G.; Costigan, M.; Anand, P.; Woolf, C.J.; et al. Identification and characterization of a novel human vanilloid receptor-like protein, VRL-2. Physiol. Genom. 2001, 4, 165-174. [CrossRef] [PubMed]

295. Schumacher, M.A.; Jong, B.E.; Frey, S.L.; Sudanagunta, S.P.; Capra, N.F.; Levine, J.D. The stretch-inactivated channel, a vanilloid receptor variant, is expressed in small-diameter sensory neurons in the rat. Neurosci. Lett. 2000, 287, 215-218. [CrossRef]

296. Suzuki, M.; Mizuno, A.; Kodaira, K.; Imai, M. Impaired pressure sensation in mice lacking TRPV4. J. Biol. Chem. 2003, 278, 22664-22668. [CrossRef] [PubMed]

297. Birder, L.; Kullmann, F.A.; Lee, H.; Barrick, S.; de Groat, W.; Kanai, A.; Caterina, M. Activation of urothelial transient receptor potential vanilloid 4 by 4 alpha-phorbol 12,13-didecanoate contributes to altered bladder reflexes in the rat. J. Pharmacol. Exp. Ther. 2007, 323, 227-235. [CrossRef] [PubMed]

298. Gevaert, T.; Vriens, J.; Segal, A.; Everaerts, W.; Roskams, T.; Talavera, K.; Owsianik, G.; Liedtke, W.; Daelemans, D.; Dewachter, I.; et al. Deletion of the transient receptor potential cation channel TRPV4 impairs murine bladder voiding. J. Clin. Investig. 2007, 117, 3453-3462. [CrossRef] [PubMed]

299. Alvarez, D.F.; King, J.A.; Weber, D.; Addison, E.; Liedtke, W.; Townsley, M.I. Transient receptor potential vanilloid 4-mediated disruption of the alveolar septal barrier: A novel mechanism of acute lung injury. Circ. Res. 2006, 99, 988-995. [CrossRef] [PubMed] 
300. Hamanaka, K.; Jian, M.Y.; Weber, D.S.; Alvarez, D.F.; Townsley, M.I.; Al-Mehdi, A.B.; King, J.A.; Liedtke, W.; Parker, J.C. TRPV4 initiates the acute calcium-dependent permeability increase during ventilator-induced lung injury in isolated mouse lungs. Am. J. Physiol. Lung Cell. Mol. Physiol. 2007, 293, L923-L932. [CrossRef] [PubMed]

301. Alessandri-Haber, N.; Dina, O.A.; Joseph, E.K.; Reichling, D.; Levine, J.D. A transient receptor potential vanilloid 4-dependent mechanism of hyperalgesia is engaged by concerted action of inflammatory mediators. J. Neurosci. 2006, 26, 3864-3874. [CrossRef] [PubMed]

302. Vennekens, R.; Hoenderop, J.G.; Prenen, J.; Stuiver, M.; Willems, P.H.; Droogmans, G.; Nilius, B.; Bindels, R.J. Permeation and gating properties of the novel epithelial $\mathrm{Ca}^{2+}$ channel. J. Biol. Chem. 2000, 275, 3963-3969. [CrossRef] [PubMed]

303. Yue, L.; Peng, J.B.; Hediger, M.A.; Clapham, D.E. CaT1 manifests the pore properties of the calciumrelease-activated calcium channel. Nature 2001, 410, 705-709. [CrossRef] [PubMed]

304. Clapham, D.E. TRP channels as cellular sensors. Nature 2003, 426, 517-524. [CrossRef] [PubMed]

305. Hoenderop, J.G.; Vennekens, R.; Müller, D.; Prenen, J.; Droogmans, G.; Bindels, R.J.; Nilius, B. Function and expression of the epithelial $\mathrm{Ca}^{2+}$ channel family: Comparison of mammalian ECaC1 and 2. J. Physiol. 2001, 537, 747-761. [CrossRef] [PubMed]

306. Lambers, T.T.; Weidema, A.F.; Nilius, B.; Hoenderop, J.G.; Bindels, R.J. Regulation of the mouse epithelial $\mathrm{Ca}^{2+}$ channel TRPV6 by the $\mathrm{Ca}^{2+}$-sensor calmodulin. J. Biol. Chem. 2004, 279, 28855-28861. [CrossRef] [PubMed]

307. Niemeyer, B.A.; Bergs, C.; Wissenbach, U.; Flockerzi, V.; Trost, C. Competitive regulation of CaT-likemediated $\mathrm{Ca}^{2+}$ entry by protein kinase $\mathrm{C}$ and calmodulin. Proc. Natl. Acad. Sci. USA 2001, 98, 3600-3605. [CrossRef] [PubMed]

308. Nilius, B.; Vennekens, R.; Prenen, J.; Hoenderop, J.G.; Bindels, R.J.; Droogmans, G. Whole-cell and single channel monovalent cation currents through the novel rabbit epithelial $\mathrm{Ca}^{2+}$ channel ECaC. J. Physiol. 2000, 527 Pt 2, 239-248. [CrossRef] [PubMed]

309. Voets, T.; Janssens, A.; Prenen, J.; Droogmans, G.; Nilius, B. $\mathrm{Mg}^{2+}$-dependent gating and strong inward rectification of the cation channel TRPV6. J. Gen. Physiol. 2003, 121, 245-260. [CrossRef] [PubMed]

310. Lee, J.; Cha, S.K.; Sun, T.J.; Huang, C.L. PIP2 activates TRPV5 and releases its inhibition by intracellular $\mathrm{Mg}^{2+}$. J. Gen. Physiol. 2005, 126, 439-451. [CrossRef] [PubMed]

311. Rohács, T.; Lopes, C.M.; Michailidis, I.; Logothetis, D.E. PI(4,5)P2 regulates the activation and desensitization of TRPM8 channels through the TRP domain. Nat. Neurosci. 2005, 8, 626-634. [CrossRef] [PubMed]

312. Thyagarajan, B.; Lukacs, V.; Rohacs, T. Hydrolysis of phosphatidylinositol 4,5-bisphosphate mediates calcium-induced inactivation of TRPV6 channels. J. Biol. Chem. 2008, 283, 14980-14987. [CrossRef] [PubMed]

313. Thyagarajan, B.; Benn, B.S.; Christakos, S.; Rohacs, T. Phospholipase C-mediated regulation of transient receptor potential vanilloid 6 channels: Implications in active intestinal $\mathrm{Ca}^{2+}$ transport. Mol. Pharmacol. 2009, 75, 608-616. [CrossRef] [PubMed]

314. Hoenderop, J.G.; van der Kemp, A.W.; Hartog, A.; van de Graaf, S.F.; van Os, C.H.; Willems, P.H.; Bindels, R.J. Molecular identification of the apical $\mathrm{Ca}^{2+}$ channel in 1, 25-dihydroxyvitamin D3-responsive epithelia. J. Biol. Chem. 1999, 274, 8375-8378. [CrossRef] [PubMed]

315. Hoenderop, J.G.; van Leeuwen, J.P.; van der Eerden, B.C.; Kersten, F.F.; van der Kemp, A.W.; Mérillat, A.M.; Waarsing, J.H.; Rossier, B.C.; Vallon, V.; Hummler, E.; et al. Renal $\mathrm{Ca}^{2+}$ wasting, hyperabsorption, and reduced bone thickness in mice lacking TRPV5. J. Clin. Investig. 2003, 112, 1906-1914. [CrossRef] [PubMed]

316. Van der Eerden, B.C.; Hoenderop, J.G.; de Vries, T.J.; Schoenmaker, T.; Buurman, C.J.; Uitterlinden, A.G.; Pols, H.A.; Bindels, R.J.; van Leeuwen, J.P. The epithelial $\mathrm{Ca}^{2+}$ channel TRPV5 is essential for proper osteoclastic bone resorption. Proc. Natl. Acad. Sci. USA 2005, 102, 17507-17512. [CrossRef] [PubMed]

317. Peng, J.B.; Chen, X.Z.; Berger, U.V.; Weremowicz, S.; Morton, C.C.; Vassilev, P.M.; Brown, E.M.; Hediger, M.A. Human calcium transport protein CaT1. Biochem. Biophys. Res. Commun. 2000, 278, 326-332. [CrossRef] [PubMed]

318. Hirnet, D.; Olausson, J.; Fecher-Trost, C.; Bödding, M.; Nastainczyk, W.; Wissenbach, U.; Flockerzi, V.; Freichel, M. The TRPV6 gene, cDNA and protein. Cell Calcium 2003, 33, 509-518. [CrossRef] 
319. Peng, J.B.; Chen, X.Z.; Berger, U.V.; Vassilev, P.M.; Tsukaguchi, H.; Brown, E.M.; Hediger, M.A. Molecular cloning and characterization of a channel-like transporter mediating intestinal calcium absorption. J. Biol. Chem. 1999, 274, 22739-22746. [CrossRef] [PubMed]

320. Zhuang, L.; Peng, J.B.; Tou, L.; Takanaga, H.; Adam, R.M.; Hediger, M.A.; Freeman, M.R. Calcium-selective ion channel, CaT1, is apically localized in gastrointestinal tract epithelia and is aberrantly expressed in human malignancies. Lab. Investig. 2002, 82, 1755-1764. [CrossRef] [PubMed]

321. Nijenhuis, T.; Hoenderop, J.G.; van der Kemp, A.W.; Bindels, R.J. Localization and regulation of the epithelial $\mathrm{Ca}^{2+}$ channel TRPV6 in the kidney. J. Am. Soc. Nephrol. 2003, 14, 2731-2740. [CrossRef] [PubMed]

322. Suzuki, Y.; Kovacs, C.S.; Takanaga, H.; Peng, J.B.; Landowski, C.P.; Hediger, M.A. Calcium channel TRPV6 is involved in murine maternal-fetal calcium transport. J. Bone Min. Res. 2008, 23, 1249-1256. [CrossRef] [PubMed]

323. Fernandes, E.S.; Vong, C.T.; Quek, S.; Cheong, J.; Awal, S.; Gentry, C.; Aubdool, A.A.; Liang, L.; Bodkin, J.V.; Bevan, S.; et al. Superoxide generation and leukocyte accumulation: Key elements in the mediation of leukotriene $\mathrm{B}_{4}$-induced itch by transient receptor potential ankyrin 1 and transient receptor potential vanilloid 1. FASEB J. 2013, 27, 1664-1673. [CrossRef] [PubMed]

324. Sisignano, M.; Park, C.K.; Angioni, C.; Zhang, D.D.; von Hehn, C.; Cobos, E.J.; Ghasemlou, N.; Xu, Z.Z.; Kumaran, V.; Lu, R.; et al. 5,6-EET is released upon neuronal activity and induces mechanical pain hypersensitivity via TRPA1 on central afferent terminals. J. Neurosci. 2012, 32, 6364-6372. [CrossRef] [PubMed]

325. Ross, R.A.; Craib, S.J.; Stevenson, L.A.; Pertwee, R.G.; Henderson, A.; Toole, J.; Ellington, H.C. Pharmacological characterization of the anandamide cyclooxygenase metabolite: Prostaglandin E2 ethanolamide. J. Pharmacol. Exp. Ther. 2002, 301, 900-907. [CrossRef] [PubMed]

326. Yu, M.; Ives, D.; Ramesha, C.S. Synthesis of prostaglandin E2 ethanolamide from anandamide by cyclooxygenase-2. J. Biol. Chem. 1997, 272, 21181-21186. [CrossRef] [PubMed]

327. Ueda, N.; Yamamoto, K.; Yamamoto, S.; Tokunaga, T.; Shirakawa, E.; Shinkai, H.; Ogawa, M.; Sato, T.; Kudo, I.; Inoue, K.; et al. Lipoxygenase-catalyzed oxygenation of arachidonylethanolamide, a cannabinoid receptor agonist. Biochim. Biophys. Acta 1995, 1254, 127-134. [CrossRef]

328. Ueda, N.; Kurahashi, Y.; Yamamoto, K.; Yamamoto, S.; Tokunaga, T. Enzymes for anandamide biosynthesis and metabolism. J. Lipid Mediat. Cell Signal. 1996, 14, 57-61. [CrossRef]

329. Craib, S.J.; Ellington, H.C.; Pertwee, R.G.; Ross, R.A. A possible role of lipoxygenases in the activation of vanilloid receptors by anandamide in the guinea-pig bronchus. Br. J. Pharmacol. 2001, 134, 30-37. [CrossRef] [PubMed]

330. Smart, D.; Gunthorpe, M.J.; Jerman, J.C.; Nasir, S.; Gray, J.; Muir, A.I.; Chambers, J.K.; Randall, A.D.; Davis, J.B. The endogenous lipid anandamide is a full agonist at the human vanilloid receptor (hVR1). Br. J. Pharmacol. 2000, 129, 227-230. [CrossRef] [PubMed]

331. Jacobsson, S.O.; Wallin, T.; Fowler, C.J. Inhibition of rat C6 glioma cell proliferation by endogenous and synthetic cannabinoids. Relative involvement of cannabinoid and vanilloid receptors. J. Pharmacol. Exp. Ther. 2001, 299, 951-959. [PubMed]

332. Sarker, K.P.; Obara, S.; Nakata, M.; Kitajima, I.; Maruyama, I. Anandamide induces apoptosis of PC-12 cells: Involvement of superoxide and caspase-3. FEBS Lett. 2000, 472, 39-44. [CrossRef]

333. Maccarrone, M.; Lorenzon, T.; Bari, M.; Melino, G.; Finazzi-Agro, A. Anandamide induces apoptosis in human cells via vanilloid receptors. Evidence for a protective role of cannabinoid receptors. J. Biol. Chem. 2000, 275, 31938-31945. [CrossRef] [PubMed]

334. Yang, Z.H.; Wang, X.H.; Wang, H.P.; Hu, L.Q.; Zheng, X.M.; Li, S.W. Capsaicin mediates cell death in bladder cancer T24 cells through reactive oxygen species production and mitochondrial depolarization. Urology 2010, 75, 735-741. [CrossRef] [PubMed]

335. Ma, F.; Zhang, L.; Westlund, K.N. Reactive oxygen species mediate TNFR1 increase after TRPV1 activation in mouse DRG neurons. Mol. Pain 2009, 5, 31. [CrossRef] [PubMed]

336. Talbot, S.; Dias, J.P.; Lahjouji, K.; Bogo, M.R.; Campos, M.M.; Gaudreau, P.; Couture, R. Activation of TRPV1 by capsaicin induces functional kinin B(1) receptor in rat spinal cord microglia. J. Neuroinflamm. 2012, 9, 16. [CrossRef] [PubMed]

337. Adam-Vizi, V.; Starkov, A.A. Calcium and mitochondrial reactive oxygen species generation: How to read the facts. J. Alzheimer Dis. 2010, 20 (Suppl. 2), S413-S426. [CrossRef] [PubMed] 
338. Nishio, S.; Teshima, Y.; Takahashi, N.; Thuc, L.C.; Saito, S.; Fukui, A.; Kume, O.; Fukunaga, N.; Hara, M.; Nakagawa, M.; et al. Activation of CaMKII as a key regulator of reactive oxygen species production in diabetic rat heart. J. Mol. Cell. Cardiol. 2012, 52, 1103-1111. [CrossRef] [PubMed]

339. Pandey, D.; Gratton, J.P.; Rafikov, R.; Black, S.M.; Fulton, D.J. Calcium/calmodulin-dependent kinase II mediates the phosphorylation and activation of NADPH oxidase 5. Mol. Pharmacol. 2011, 80, 407-415. [CrossRef] [PubMed]

340. Kishimoto, E.; Naito, Y.; Handa, O.; Okada, H.; Mizushima, K.; Hirai, Y.; Nakabe, N.; Uchiyama, K.; Ishikawa, T.; Takagi, T.; et al. Oxidative stress-induced posttranslational modification of TRPV1 expressed in esophageal epithelial cells. Am. J. Physiol. Gastrointest. Liver Physiol. 2011, 301, G230-G238. [CrossRef] [PubMed]

341. Yoshida, T.; Inoue, R.; Morii, T.; Takahashi, N.; Yamamoto, S.; Hara, Y.; Tominaga, M.; Shimizu, S.; Sato, Y.; Mori, Y. Nitric oxide activates TRP channels by cysteine S-nitrosylation. Nat. Chem. Biol. 2006, 2, 596-607. [CrossRef] [PubMed]

342. Takahashi, N.; Mori, Y. TRP Channels as Sensors and Signal Integrators of Redox Status Changes. Front. Pharmacol. 2011, 2, 58. [CrossRef] [PubMed]

343. Susankova, K.; Tousova, K.; Vyklicky, L.; Teisinger, J.; Vlachova, V. Reducing and oxidizing agents sensitize heat-activated vanilloid receptor (TRPV1) current. Mol. Pharmacol. 2006, 70, 383-394. [CrossRef] [PubMed]

344. Taylor-Clark, T.E.; McAlexander, M.A.; Nassenstein, C.; Sheardown, S.A.; Wilson, S.; Thornton, J.; Carr, M.J.; Undem, B.J. Relative contributions of TRPA1 and TRPV1 channels in the activation of vagal bronchopulmonary C-fibres by the endogenous autacoid 4-oxononenal. J. Physiol. 2008, 586, 347-359. [CrossRef] [PubMed]

345. Pei, Z.; Zhuang, Z.; Sang, H.; Wu, Z.; Meng, R.; He, E.Y.; Scott, G.I.; Maris, J.R.; Li, R.; Ren, J. $\alpha, \beta$-Unsaturated aldehyde crotonaldehyde triggers cardiomyocyte contractile dysfunction: Role of TRPV1 and mitochondrial function. Pharmacol. Res. 2014, 82, 40-50. [CrossRef] [PubMed]

346. Inoue, I.; Goto, S.; Matsunaga, T.; Nakajima, T.; Awata, T.; Hokari, S.; Komoda, T.; Katayama, S. The ligands/activators for peroxisome proliferator-activated receptor alpha (PPARalpha) and PPARgamma increase $\mathrm{Cu}^{2+}, \mathrm{Zn}^{2+}$-superoxide dismutase and decrease p22phox message expressions in primary endothelial cells. Metabolism 2001, 50, 3-11. [CrossRef] [PubMed]

347. Girnun, G.D.; Domann, F.E.; Moore, S.A.; Robbins, M.E. Identification of a functional peroxisome proliferator-activated receptor response element in the rat catalase promoter. Mol. Endocrinol. 2002, 16, 2793-2801. [CrossRef] [PubMed]

348. Diep, Q.N.; Amiri, F.; Touyz, R.M.; Cohn, J.S.; Endemann, D.; Neves, M.F.; Schiffrin, E.L. PPARalpha activator effects on Ang II-induced vascular oxidative stress and inflammation. Hypertension 2002, 40, 866-871. [CrossRef] [PubMed]

349. Landmesser, U.; Cai, H.; Dikalov, S.; McCann, L.; Hwang, J.; Jo, H.; Holland, S.M.; Harrison, D.G. Role of p47 in vascular oxidative stress and hypertension caused by angiotensin II. Hypertension 2002, 40, 511-515. [CrossRef] [PubMed]

350. Martinez, A.A.; Morgese, M.G.; Pisanu, A.; Macheda, T.; Paquette, M.A.; Seillier, A.; Cassano, T.; Carta, A.R.; Giuffrida, A. Activation of PPAR gamma receptors reduces levodopa-induced dyskinesias in 6-OHDA-lesioned rats. Neurobiol. Dis. 2015, 74, 295-304. [CrossRef] [PubMed]

351. Impellizzeri, D.; Esposito, E.; Attley, J.; Cuzzocrea, S. Targeting inflammation: New therapeutic approaches in chronic kidney disease (CKD). Pharmacol. Res. 2014, 81, 91-102. [CrossRef] [PubMed]

352. Di Paola, R.; Impellizzeri, D.; Mondello, P.; Velardi, E.; Aloisi, C.; Cappellani, A.; Esposito, E.; Cuzzocrea, S. Palmitoylethanolamide reduces early renal dysfunction and injury caused by experimental ischemia and reperfusion in mice. Shock 2012, 38, 356-366. [CrossRef] [PubMed]

353. Moreno, S.; Mugnaini, E.; Ceru, M.P. Immunocytochemical localization of catalase in the central nervous system of the rat. J. HistoChem. Cytochem. 1995, 43, 1253-1267. [CrossRef] [PubMed]

354. Moreno, S.; Nardacci, R.; Ceru, M.P. Regional and ultrastructural immunolocalization of copper-zinc superoxide dismutase in rat central nervous system. J. Histochem. Cytochem. 1997, 45, 1611-1622. [CrossRef] [PubMed]

355. Farioli-Vecchioli, S.; Moreno, S.; Ceru, M.P. lmmunocytochemical localization of acyl-CoA oxidase in the rat central nervous system. J. Neurocytol. 2001, 30, 21-33. [CrossRef] [PubMed] 
356. Poynter, M.E.; Daynes, R.A. Peroxisome proliferator-activated receptor alpha activation modulates cellular redox status, represses nuclear factor-kappaB signaling, and reduces inflammatory cytokine production in aging. J. Biol. Chem. 1998, 273, 32833-32841. [CrossRef] [PubMed]

357. Cimini, A.; Benedetti, E.; Cristiano, L.; Sebastiani, P.; D’Amico, M.A.; D'Angelo, B.; Di Loreto, S. Expression of peroxisome proliferator-activated receptors (PPARs) and retinoic acid receptors (RXRs) in rat cortical neurons. Neuroscience 2005, 130, 325-337. [CrossRef] [PubMed]

358. Sayre, L.M.; Perry, G.; Smith, M.A. Oxidative Stress and Neurotoxicity. Chem. Res. Toxicol. 2008, 21, 172-188. [CrossRef] [PubMed]

359. Sultana, R.; Butterfield, D.A. Role of oxidative stress in the progression of Alzheimer's disease. J. Alzheimer Dis. 2010, 19, 341-353. [CrossRef] [PubMed]

360. Fanelli, F.; Sepe, S.; D'Amelio, M.; Bernardi, C.; Cristiano, L.; Cimini, A.; Cecconi, F.; Ceru', M.P.; Moreno, S. Age-dependent roles of peroxisomes in the hippocampus of a transgenic mouse model of Alzheimer's disease. Mol. Neurodegener. 2013, 8, 8. [CrossRef] [PubMed]

361. Duncan, R.S.; Chapman, K.D.; Koulen, P. The neuroprotective properties of palmitoylethanolamine against oxidative stress in a neuronal cell line. Mol. Neurodegener. 2009, 4, 50. [CrossRef] [PubMed]

362. Raso, G.M.; Esposito, E.; Vitiello, S.; Iacono, A.; Santoro, A.; D’Agostino, G.; Sasso, O.; Russo, R.; Piazza, P.V.; Calignano, A.; et al. Palmitoylethanolamide stimulation induces allopregnanolone synthesis in C6 Cells and primary astrocytes: Involvement of peroxisome-proliferator activated receptor-a. J. Neuroendocrinol. 2011, 23, 591-600. [CrossRef] [PubMed]

363. Avagliano, C.; Russo, R.; De Caro, C.; Cristiano, C.; La Rana, G.; Piegari, G.; Paciello, O.; Citraro, R.; Russo, E.; De Sarro, G.; et al. Palmitoylethanolamide protects mice against 6-OHDA-induced neurotoxicity and endoplasmic reticulum stress: In vivo and in vitro evidence. Pharmacol. Res. 2016, 113, 276-289. [CrossRef] [PubMed]

364. Manea, A.; Manea, S.A.; Todirita, A.; Albulescu, I.C.; Raicu, M.; Sasson, S.; Simionescu, M. High-glucose-increased expression and activation of NADPH oxidase in human vascular smooth muscle cells is mediated by 4-hydroxynonenal-activated PPAR $\alpha$ and PPAR $\beta / \delta$. Cell Tissue Res. 2015, 361, 593-604. [CrossRef] [PubMed]

365. Irving, A.; Abdulrazzaq, G.; Chan, S.L.F.; Penman, J.; Harvey, J.; Alexander, S.P.H. Cannabinoid Receptor-Related Orphan G Protein-Coupled Receptors. Adv. Pharmacol. 2017, 80, 223-247. [CrossRef] [PubMed]

366. Gantz, I.; Muraoka, A.; Yang, Y.K.; Samuelson, L.C.; Zimmerman, E.M.; Cook, H.; Yamada, T. Cloning and chromosomal localization of a gene (GPR18) encoding a novel seven transmembrane receptor highly expressed in spleen and testis. Genomics 1997, 42, 462-466. [CrossRef] [PubMed]

367. Vassilatis, D.K.; Hohmann, J.G.; Zeng, H.; Li, F.; Ranchalis, J.E.; Mortrud, M.T.; Brown, A.; Rodriguez, S.S.; Weller, J.R.; Wright, A.C.; et al. The G protein-coupled receptor repertoires of human and mouse. Proc. Natl. Acad. Sci. USA 2003, 100, 4903-4908. [CrossRef] [PubMed]

368. Lu, V.B.; Puhl, H.L., 3rd; Ikeda, S.R. N-Arachidonyl glycine does not activate G protein-coupled receptor 18 signaling via canonical pathways. Mol. Pharmacol. 2013, 83, 267-282. [CrossRef] [PubMed]

369. Finlay, D.B.; Joseph, W.R.; Grimsey, N.L.; Glass, M. GPR18 undergoes a high degree of constitutive trafficking but is unresponsive to $N$-Arachidonoyl Glycine. Peer] 2016, 4, e1835. [CrossRef] [PubMed]

370. Penumarti, A.; Abdel-Rahman, A.A. The novel endocannabinoid receptor GPR18 is expressed in the rostral ventrolateral medulla and exerts tonic restraining influence on blood pressure. J. Pharmacol. Exp. Ther. 2014, 349, 29-38. [CrossRef] [PubMed]

371. Matouk, A.I.; Taye, A.; El-Moselhy, M.A.; Heeba, G.H.; Abdel-Rahman, A.A. The Effect of Chronic Activation of the Novel Endocannabinoid Receptor GPR18 on Myocardial Function and Blood Pressure in Conscious Rats. J. Cardiovasc. Pharmacol. 2017, 69, 23-33. [CrossRef] [PubMed]

372. Sawzdargo, M.; Nguyen, T.; Lee, D.K.; Lynch, K.R.; Cheng, R.; Heng, H.H.; George, S.R.; O’Dowd, B.F. Identification and cloning of three novel human $\mathrm{G}$ protein-coupled receptor genes GPR52, PsiGPR53 and GPR55: GPR55 is extensively expressed in human brain. Brain Res. Mol. Brain Res. 1999, 64, 193-198. [CrossRef]

373. Ryberg, E.; Larsson, N.; Sjögren, S.; Hjorth, S.; Hermansson, N.O.; Leonova, J.; Elebring, T.; Nilsson, K.; Drmota, T.; Greasley, P.J. The orphan receptor GPR55 is a novel cannabinoid receptor. Br. J. Pharmacol. 2007, 152, 1092-1101. [CrossRef] [PubMed] 
374. Romero-Zerbo, S.Y.; Rafacho, A.; Díaz-Arteaga, A.; Suárez, J.; Quesada, I.; Imbernon, M.; Ross, R.A.; Dieguez, C.; Rodríguez de Fonseca, F.; Nogueiras, R.; et al. A role for the putative cannabinoid receptor GPR55 in the islets of Langerhans. J. Endocrinol. 2011, 211, 177-185. [CrossRef] [PubMed]

375. Whyte, L.S.; Ryberg, E.; Sims, N.A.; Ridge, S.A.; Mackie, K.; Greasley, P.J.; Ross, R.A.; Rogers, M.J. The putative cannabinoid receptor GPR55 affects osteoclast function in vitro and bone mass in vivo. Proc. Natl. Acad. Sci. USA 2009, 106, 16511-16516. [CrossRef] [PubMed]

376. Pietr, M.; Kozela, E.; Levy, R.; Rimmerman, N.; Lin, Y.H.; Stella, N.; Vogel, Z.; Juknat, A. Differential changes in GPR55 during microglial cell activation. FEBS Lett. 2009, 583, 2071-2076. [CrossRef] [PubMed]

377. Waldeck-Weiermair, M.; Zoratti, C.; Osibow, K.; Balenga, N.; Goessnitzer, E.; Waldhoer, M.; Malli, R.; Graier, W.F. Integrin clustering enables anandamide-induced $\mathrm{Ca}^{2+}$ signaling in endothelial cells via GPR55 by protection against CB1-receptor-triggered repression. J. Cell Sci. 2008, 121, 1704-1717. [CrossRef] [PubMed]

378. Kapur, A.; Zhao, P.; Sharir, H.; Bai, Y.; Caron, M.G.; Barak, L.S.; Abood, M.E. Atypical responsiveness of the orphan receptor GPR55 to cannabinoid ligands. J. Biol. Chem. 2009, 284, 29817-29827. [CrossRef] [PubMed]

379. Yin, H.; Chu, A.; Li, W.; Wang, B.; Shelton, F.; Otero, F.; Nguyen, D.G.; Caldwell, J.S.; Chen, Y.A. Lipid G protein-coupled receptor ligand identification using beta-arrestin PathHunter assay. J. Biol. Chem. 2009, 284, 12328-12338. [CrossRef] [PubMed]

380. Henstridge, C.M.; Balenga, N.A.; Ford, L.A.; Ross, R.A.; Waldhoer, M.; Irving, A.J. The GPR55 ligand L-alpha-lysophosphatidylinositol promotes RhoA-dependent $\mathrm{Ca}^{2+}$ signaling and NFAT activation. FASEB J. 2009, 23, 183-193. [CrossRef] [PubMed]

381. Oka, S.; Toshida, T.; Maruyama, K.; Nakajima, K.; Yamashita, A.; Sugiura, T. 2-Arachidonoyl-sn-glycero3-phosphoinositol: A possible natural ligand for GPR55. J. Biochem. 2009, 145, 13-20. [CrossRef] [PubMed]

382. Oka, S.; Nakajima, K.; Yamashita, A.; Kishimoto, S.; Sugiura, T. Identification of GPR55 as a lysopho sphatidylinositol receptor. Biochem. Biophys. Res. Commun. 2007, 362, 928-934. [CrossRef] [PubMed]

383. Bondarenko, A.; Waldeck-Weiermair, M.; Naghdi, S.; Poteser, M.; Malli, R.; Graier, W.F. GPR55-dependent and -independent ion signalling in response to lysophosphatidylinositol in endothelial cells. Br. J. Pharmacol. 2010, 161, 308-320. [CrossRef] [PubMed]

384. Moreno, E.; Andradas, C.; Medrano, M.; Caffarel, M.M.; Pérez-Gómez, E.; Blasco-Benito, S.; Gómez-Cañas, M.; Pazos, M.R.; Irving, A.J.; Lluís, C.; et al. Targeting CB2-GPR55 receptor heteromers modulates cancer cell signaling. J. Biol. Chem. 2014, 289, 21960-21972. [CrossRef] [PubMed]

385. Fredriksson, R.; Höglund, P.J.; Gloriam, D.E.; Lagerström, M.C.; Schiöth, H.B. Seven evolutionarily conserved human rhodopsin G protein-coupled receptors lacking close relatives. FEBS Lett. 2003, 554, 381-388. [CrossRef]

386. Soga, T.; Ohishi, T.; Matsui, T.; Saito, T.; Matsumoto, M.; Takasaki, J.; Matsumoto, S.; Kamohara, M.; Hiyama, H.; Yoshida, S.; et al. Lysophosphatidylcholine enhances glucose-dependent insulin secretion via an orphan G-protein-coupled receptor. Biochem. Biophys. Res. Commun. 2005, 326, 744-751. [CrossRef] [PubMed]

387. Sakamoto, Y.; Inoue, H.; Kawakami, S.; Miyawaki, K.; Miyamoto, T.; Mizuta, K.; Itakura, M. Expression and distribution of Gpr119 in the pancreatic islets of mice and rats: Predominant localization in pancreatic polypeptide-secreting PP-cells. Biochem. Biophys. Res. Commun. 2006, 351, 474-480. [CrossRef] [PubMed]

388. Chu, Z.L.; Carroll, C.; Alfonso, J.; Gutierrez, V.; He, H.; Lucman, A.; Pedraza, M.; Mondala, H.; Gao, H.; Bagnol, D.; et al. A role for intestinal endocrine cell-expressed g protein-coupled receptor 119 in glycemic control by enhancing glucagon-like Peptide-1 and glucose-dependent insulinotropic Peptide release. Endocrinology 2008, 149, 2038-2047. [CrossRef] [PubMed]

389. Lauffer, L.M.; Iakoubov, R.; Brubaker, P.L. GPR119 is essential for oleoylethanolamide-induced glucagon-like peptide-1 secretion from the intestinal enteroendocrine L-cell. Diabetes 2009, 58, 1058-1066. [CrossRef] [PubMed]

390. Yang, J.W.; Kim, H.S.; Im, J.H.; Kim, J.W.; Jun, D.W.; Lim, S.C.; Lee, K.; Choi, J.M.; Kim, S.K.; Kang, K.W. GPR119: A promising target for nonalcoholic fatty liver disease. FASEB J. 2016, 30, 324-335. [CrossRef] [PubMed] 
391. Cvijanovic, N.; Isaacs, N.J.; Rayner, C.K.; Feinle-Bisset, C.; Young, R.L.; Little, T.J. Duodenal fatty acid sensor and transporter expression following acute fat exposure in healthy lean humans. Clin. Nutr. 2017, 36, 564-569. [CrossRef] [PubMed]

392. Overton, H.A.; Babbs, A.J.; Doel, S.M.; Fyfe, M.C.; Gardner, L.S.; Griffin, G.; Jackson, H.C.; Procter, M.J.; Rasamison, C.M.; Tang-Christensen, M.; et al. Deorphanization of a G protein-coupled receptor for oleoylethanolamide and its use in the discovery of small-molecule hypophagic agents. Cell Metab. 2006, 3, 167-175. [CrossRef] [PubMed]

393. Chu, Z.L.; Carroll, C.; Chen, R.; Alfonso, J.; Gutierrez, V.; He, H.; Lucman, A.; Xing, C.; Sebring, K.; Zhou, J.; et al. N-oleoyldopamine enhances glucose homeostasis through the activation of GPR119. Mol. Endocrinol. 2010, 24, 161-170. [CrossRef] [PubMed]

394. Hansen, K.B.; Rosenkilde, M.M.; Knop, F.K.; Wellner, N.; Diep, T.A.; Rehfeld, J.F.; Andersen, U.B.; Holst, J.J.; Hansen, H.S. 2-Oleoyl glycerol is a GPR119 agonist and signals GLP-1 release in humans. J. Clin. Endocrinol. Metab. 2011, 96, E1409-E1417. [CrossRef] [PubMed]

395. Balenga, N.A.; Aflaki, E.; Kargl, J.; Platzer, W.; Schröder, R.; Blättermann, S.; Kostenis, E.; Brown, A.J.; Heinemann, A.; Waldhoer, M. GPR55 regulates cannabinoid 2 receptor-mediated responses in human neutrophils. Cell Res. 2011, 21, 1452-1469. [CrossRef] [PubMed]

396. Chiurchiù, V.; Lanuti, M.; De Bardi, M.; Battistini, L.; Maccarrone, M. The differential characterization of GPR55 receptor in human peripheral blood reveals a distinctive expression in monocytes and NK cells and a proinflammatory role in these innate cells. Int. Immunol. 2015, 27, 153-160. [CrossRef] [PubMed]

397. He, L.; He, T.; Farrar, S.; Ji, L.; Liu, T.; Ma, X. Antioxidants Maintain Cellular Redox Homeostasis by Elimination of Reactive Oxygen Species. Cell. Physiol. Biochem. 2017, 44, 532-553. [CrossRef] [PubMed]

398. Chelikani, P.; Fita, I.; Loewen, P.C. Diversity of structures and properties among catalases. Cell. Mol. Life Sci. 2004, 61, 192-208. [CrossRef] [PubMed]

399. Bannister, J.V.; Bannister, W.H.; Rotilio, G. Aspects of the structure, function, and applications of superoxide dismutase. CRC Crit. Rev. Biochem. 1987, 22, 111-180. [CrossRef] [PubMed]

400. Zelko, I.N.; Mariani, T.J.; Folz, R.J. Superoxide dismutase multigene family: A comparison of the CuZn-SOD (SOD1), Mn-SOD (SOD2), and EC-SOD (SOD3) gene structures, evolution, and expression. Free Radic. Biol. Med. 2002, 33, 337-349. [CrossRef]

401. Brigelius-Flohé, R. Tissue-specific functions of individual glutathione peroxidases. Free Radic. Biol. Med. 1999, 27, 951-965. [CrossRef]

402. Arnér, E.S.; Holmgren, A. Physiological functions of thioredoxin and thioredoxin reductase. Eur. J. Biochem. 2000, 267, 6102-6109. [CrossRef] [PubMed]

403. Meister, A.; Anderson, M.E. Glutathione. Annu. Rev. Biochem. 1983, 52, 711-760. [CrossRef] [PubMed]

404. Palace, V.P.; Khaper, N.; Qin, Q.; Singal, P.K. Antioxidant potentials of vitamin A and carotenoids and their relevance to heart disease. Free Radic. Biol. Med. 1999, 26, 746-761. [CrossRef]

405. Rice, M.E. Ascorbate regulation and its neuroprotective role in the brain. Trends Neurosci. 2000, 23, $209-216$. [CrossRef]

406. McCay, P.B. Vitamin E: Interactions with free radicals and ascorbate. Annu. Rev. Nutr. 1985, 5, 323-340. [CrossRef] [PubMed]

407. Turunen, M.; Olsson, J.; Dallner, G. Metabolism and function of coenzyme Q. Biochim. Biophys. Acta 2004, 1660, 171-199. [CrossRef] [PubMed]

408. Paiva, S.A.; Russell, R.M. Beta-carotene and other carotenoids as antioxidants. J. Am. Coll. Nutr. 1999, 18, 426-433. [CrossRef] [PubMed]

409. Giudetti, A.M.; Salzet, M.; Cassano, T. Oxidative Stress in Aging Brain: Nutritional and Pharmacological Interventions for Neurodegenerative Disorders. Oxid. Med. Cell. Longev. 2018, 2018, 3416028. [CrossRef] [PubMed]

410. Heim, K.E.; Tagliaferro, A.R.; Bobilya, D.J. Flavonoid antioxidants: Chemistry, metabolism and structure-activity relationships. J. Nutr. Biochem. 2002, 13, 572-584. [CrossRef]

411. Sandoval-Acuña, C.; Ferreira, J.; Speisky, H. Polyphenols and mitochondria: An update on their increasingly emerging ROS-scavenging independent actions. Arch. Biochem. Biophys. 2014, 559, 75-90. [CrossRef] [PubMed]

412. Tabassum, A.; Bristow, R.G.; Venkateswaran, V. Ingestion of selenium and other antioxidants during prostate cancer radiotherapy: A good thing? Cancer Treat. Rev. 2010, 36, 230-234. [CrossRef] [PubMed] 
413. Prasad, A.S.; Bao, B.; Beck, F.W.; Kucuk, O.; Sarkar, F.H. Antioxidant effect of zinc in humans. Free Radic. Biol. Med. 2004, 37, 1182-1190. [CrossRef] [PubMed]

414. Rizzo, A.M.; Berselli, P.; Zava, S.; Montorfano, G.; Negroni, M.; Corsetto, P.; Berra, B. Endogenous antioxidants and radical scavengers. Adv. Exp. Med. Biol. 2010, 698, 52-67. [CrossRef] [PubMed]

415. Reiter, R.J.; Tan, D.X.; Poeggeler, B.; Menendez-Pelaez, A.; Chen, L.D.; Saarela, S. Melatonin as a free radical scavenger: Implications for aging and age-related diseases. Ann. N. Y. Acad. Sci. 1994, 719, 1-12. [CrossRef] [PubMed]

416. Burton, G.W.; Traber, M.G. Vitamin E: Antioxidant activity, biokinetics, and bioavailability. Annu. Rev. Nutr. 1990, 10, 357-382. [CrossRef] [PubMed]

417. Bowman, G.L.; Shannon, J.; Frei, B.; Kaye, J.A.; Quinn, J.F. Uric acid as a CNS antioxidant. J. Alzheimer Dis. 2010, 19, 1331-1336. [CrossRef] [PubMed]

418. Cotelle, N. Role of flavonoids in oxidative stress. Curr. Top. Med. Chem. 2001, 1, 569-590. [CrossRef] [PubMed]

419. Hussain, T.; Tan, B.; Yin, Y.; Blachier, F.; Tossou, M.C.; Rahu, N. Oxidative Stress and Inflammation: What Polyphenols Can Do for Us? Oxid. Med. Cell. Longev. 2016, 2016, 7432797. [CrossRef] [PubMed]

420. Martinez, J.; Moreno, J.J. Role of $\mathrm{Ca}^{2+}$-Independent Phospholipase $\mathrm{A}_{2}$ on Arachidonic Acid Release Induced by Reactive Oxygen Species. Arch. Biochem. Biophys. 2001, 392, 257-262. [CrossRef] [PubMed]

421. Bátkai, S.; Rajesh, M.; Mukhopadhyay, P.; Haskó, G.; Liaudet, L.; Cravatt, B.F.; Csiszár, A.; Ungvári, Z.; Pacher, P. Decreased age-related cardiac dysfunction, myocardial nitrative stress, inflammatory gene expression, and apoptosis in mice lacking fatty acid amide hydrolase. Am. J. Physiol. Heart Circ. Physiol. 2007, 293, H909-H918. [CrossRef] [PubMed]

422. Wei, Y.; Wang, X.; Wang, L. Presence and regulation of cannabinoid receptors in human retinal pigment epithelial cells. Mol. Vis. 2009, 15, 1243-1251. [PubMed]

423. Wang, M.; Abais, J.M.; Meng, N.; Zhang, Y.; Ritter, J.K.; Li, P.L.; Tang, W.X. Upregulation of cannabinoid receptor-1 and fibrotic activation of mouse hepatic stellate cells during Schistosoma J. infection: Role of NADPH oxidase. Free Radic. Biol. Med. 2014, 71, 109-120. [CrossRef] [PubMed] 